\title{
A Hexapodal Capsule for the Recognition of Anions
}

Han Xie, ${ }^{[a]}$ Tyler J. Finnegan, ${ }^{[a]}$ Vageesha W. Liyana Gunawardana, ${ }^{[a]}$ Radoslav Z. Pavlović,,${ }^{[a]}$ Curtis E. Moore, ${ }^{[\mathrm{a}]}$ Jovica D. Badjić $[\mathrm{a}] *$

${ }^{[a]}$ Department of Chemistry \& Biochemistry, The Ohio State University, 100 West 18th Avenue, 43210 Columbus, Ohio.

E-mail: badjic.1@osu.edu

\section{SUPPORTING INFORMATION}




\section{Table of Contents}

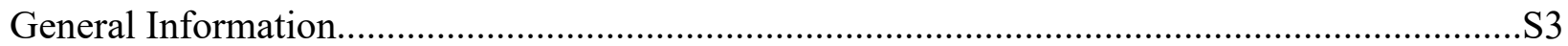

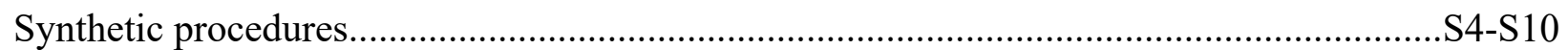

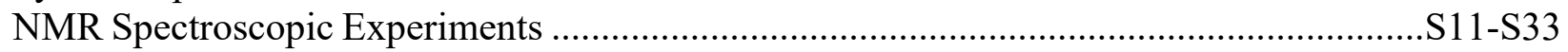

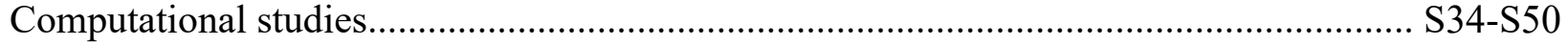

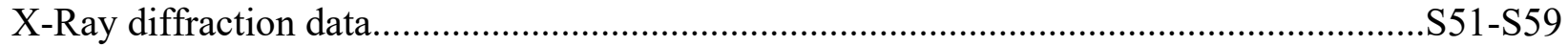




\section{General Information}

All chemicals were purchased from commercial sources and used as received unless stated otherwise. Chromatographic purifications were completed with silica gel $60\left(\mathrm{SiO}_{2}\right.$, Sorbent Technologies $40-75 \mu \mathrm{m}, 200 \times 400 \mathrm{mesh}$ ). Thin-layer chromatography (TLC) studies were completed with silica-gel plates w/UV254 $(200 \mu \mathrm{m})$. For NMR studies, we used class B glass NMR tubes (Wilmad Lab Glass). NMR experiments were completed with Bruker 400, 600, 700 and $850 \mathrm{MHz}$ spectrometers. Chemical shifts are expressed in parts per million $(\delta, \mathrm{ppm})$ while coupling constant values $(J)$ are given in Hertz $(\mathrm{Hz})$. Residual solvent protons were used as an internal standard: for ${ }^{1} \mathrm{H}$ NMR spectra $\mathrm{CDCl}_{3}=7.26 \mathrm{ppm}$ and $\left(\mathrm{CD}_{3}\right)_{2} \mathrm{SO}=2.50 \mathrm{ppm}$, while for

${ }^{13} \mathrm{C}$ NMR spectra $\mathrm{CDCl}_{3}=77.0 \mathrm{ppm}$ and $\left(\mathrm{CD}_{3}\right)_{2} \mathrm{SO}=39.52 \mathrm{ppm}$. Deuterated solvents $\mathrm{CDCl}_{3}$ and $\left(\mathrm{CD}_{3}\right)_{2} \mathrm{SO}$ were purchased from Cambridge Isotope Laboratories. HRMS data were obtained with a Bruker-ESI TOF instrument. 


\section{Synthetic Procedures}

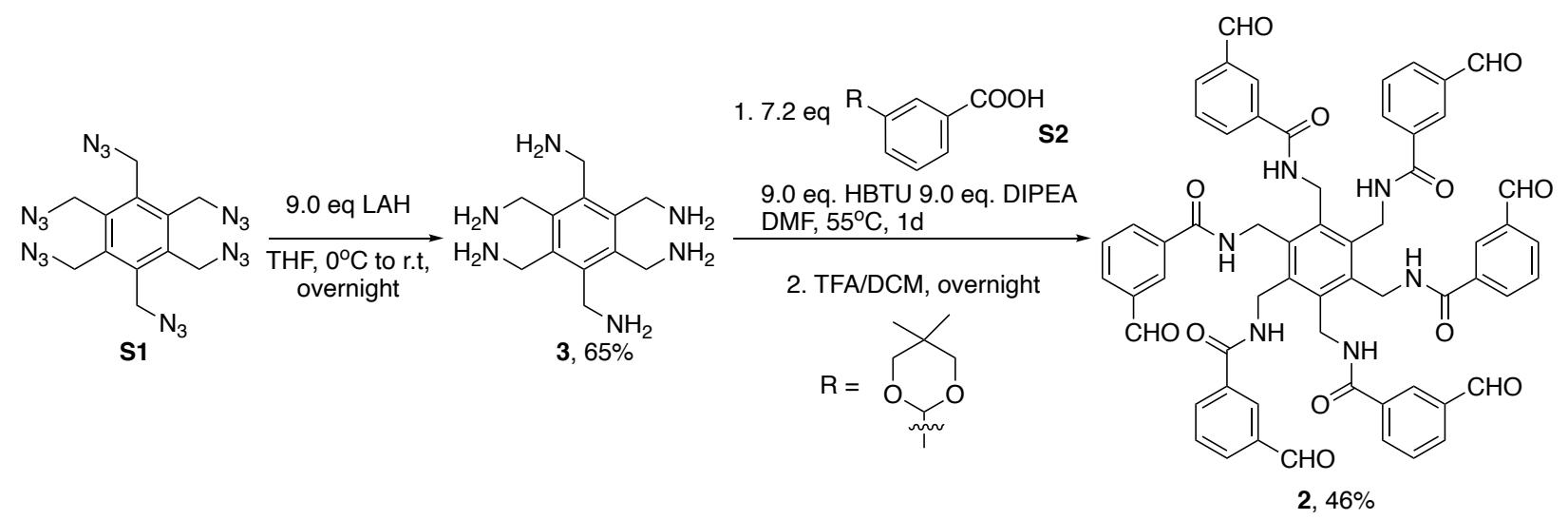

Scheme S1. A synthetic scheme describing the preparation of hexakis-aldehyde 2; note that compound S1 was obtained in $95 \%$ yield from commercially available hexamethylbenzene following published procedures (see: Macromolecules, 2006, 39, 6800-6810 and Chem. Eur. J., 2012, 18, $5064-5072$ ).

Compound 3: To compound S1 (500 mg, $1.22 \mathrm{mmol})$ in $40 \mathrm{~mL}$ of dry THF at $0{ }^{\circ} \mathrm{C}$ and under an atmosphere of nitrogen, $\mathrm{LiAlH}_{4}(415 \mathrm{mg}, 10.9 \mathrm{mmol})$ was added in four portions. The reaction mixture was stirred at $0{ }^{\circ} \mathrm{C}$ for 3 hours then brought to a room temperature by stirring overnight. After cooling the reaction mixture to $0{ }^{\circ} \mathrm{C}, \mathrm{H}_{2} \mathrm{O}(415 \mu \mathrm{L}), \mathrm{NaOH}(15 \mathrm{wt} \%$ in water, $415 \mu \mathrm{L})$ and $\mathrm{H}_{2} \mathrm{O}(1.25 \mathrm{~mL})$ were added consecutively in a dropwise manner. After addition of $20 \mathrm{~mL}$ of isopropanol, the mixture was filtrated through a pad of celite. The solvent from filtrate was removed by blowing nitrogen over it to give 3 as a white solid $(200 \mathrm{mg}, 65 \%)$. ${ }^{1} \mathrm{H} \mathrm{NMR}(600 \mathrm{MHz}$, $\left.\mathrm{CDCl}_{3}\right): \delta(\mathrm{ppm})=4.06(\mathrm{~s}, 12 \mathrm{H}) ;{ }^{13} \mathrm{C} \mathrm{NMR}\left(151 \mathrm{MHz}, \mathrm{CDCl}_{3}\right): \delta(\mathrm{ppm})=139.96,40.64$. HRMS (ESI): $m / z$ calcd for $\mathrm{C}_{12} \mathrm{H}_{25} \mathrm{~N}_{6}{ }^{+}: 253.2141$; found: 253.2131 . See Figure $\mathbf{S 3 1}$ for ${ }^{1} \mathrm{H}$ and ${ }^{13} \mathrm{C}$ NMR spectra of $\mathbf{3}$.

Compound S2: A solution of 3-formylbenzoic acid (200 mg, $1.33 \mathrm{mmol})$, neopentyl glycol (153 $\mathrm{mg}, 1.46 \mathrm{mmol})$ and $p$-toluenesulfonic acid monohydrate $(13 \mathrm{mg} 0.07 \mathrm{mmol})$ in $10 \mathrm{~mL}$ toluene was brought to reflux with a dean stark apparatus and kept as such for $12 \mathrm{~h}$. Following, the reaction mixture was stirred overnight to cool to a room temperature. The solvent was removed under reduced pressure and the crude mixture purified using silica chromatography (hexane: EtOAc $=$ 5:1 to 3:1) to give $\mathbf{S 2}$ as a white solid (235 mg, 75\%). ${ }^{1} \mathrm{H}$ NMR $\left(400 \mathrm{MHz}, \mathrm{CDCl}_{3}\right): \delta(\mathrm{ppm})=8.40$ $(\mathrm{s}, 1 \mathrm{H}), 8.26-8.24(\mathrm{~d}, 1 \mathrm{H}, J=7.9 \mathrm{~Hz}), 7.94-7.92(\mathrm{~d}, 1 \mathrm{H}, J=7.7 \mathrm{~Hz}), 7.67-7.63(\mathrm{t}, 1 \mathrm{H}, J=7.8 \mathrm{~Hz})$, $5.61(\mathrm{~s}, 1 \mathrm{H}), 3.96-3.81(\mathrm{~m}, 4 \mathrm{H}), 1.46(\mathrm{~s}, 3 \mathrm{H}), 0.97(\mathrm{~s}, 3 \mathrm{H}) \cdot{ }^{13} \mathrm{C} \mathrm{NMR}\left(101 \mathrm{MHz}, \mathrm{CDCl}_{3}\right): \delta(\mathrm{ppm})$ $=171.46,139.24,131.70,130.77,129.46,128.71,128.39,101.06,77.82,30.41,23.21,22.02$. HRMS (ESI): $m / z$ calcd for $\mathrm{C}_{13} \mathrm{H}_{16} \mathrm{NaO}_{4}{ }^{+}: 259.0946$; found: 259.0941 . See Figure $\mathbf{S 3 3}$ for ${ }^{1} \mathrm{H}$ and ${ }^{13} \mathrm{C}$ NMR spectra of $\mathbf{S 2}$.

Compound 2: To a solution of 3 (160 mg, $0.63 \mathrm{mmol}), \mathbf{S 2}(1.08 \mathrm{~g}, 4.6 \mathrm{mmol})$ and HBTU (2.1 g, $5.5 \mathrm{mmol})$ in $15 \mathrm{~mL}$ of dry DMF, DIPEA $(1 \mathrm{~mL}, 5.5 \mathrm{mmol})$ was added in one portion. The reaction mixture was stirred at $55^{\circ} \mathrm{C}$ under an atmosphere of nitrogen for one day. After its cooling to $0{ }^{\circ} \mathrm{C}$ followed by the addition of $20 \mathrm{~mL}$ of $\mathrm{H}_{2} \mathrm{O}$, the mixture was extracted with EtOAc $(3 \times 20 \mathrm{~mL})$. 
The organic layer was washed with $\mathrm{H}_{2} \mathrm{O}(3 \times 5 \mathrm{~mL})$, brine $(10 \mathrm{~mL})$ and then dried over $\mathrm{Na}_{2} \mathrm{SO}_{4}$. After the solvent removal at a low pressure, protected 2 (as hexa acetal) was isolated by silica chromatography $\left(\mathrm{CH}_{2} \mathrm{Cl}_{2}\right.$ : acetone $=2: 1$ to $\left.1: 1\right)$ as an off-white solid. This product was dissolved in $40 \mathrm{~mL}$ of $\mathrm{CH}_{2} \mathrm{Cl}_{2}$ : TFA $=3: 1$ and then stirred overnight at a room temperature. The solvent was removed under vacuum and the crude product washed with EtOAc $(3 \times 5 \mathrm{~mL})$ to give 2 as a white solid (310 mg, 46\%). ${ }^{1} \mathrm{H}$ NMR (400 MHz, DMSO- $\left.d_{6}\right): \delta(\mathrm{ppm})=9.82(\mathrm{~s}, 6 \mathrm{H}), 8.85-8.84(\mathrm{t}, 6 \mathrm{H}, J$ $=3.9 \mathrm{~Hz}), 8.16(\mathrm{~s}, 6 \mathrm{H}), 7.99-7.98(\mathrm{~d}, 6 \mathrm{H}, J=7.8 \mathrm{~Hz}), 7.85-7.84(\mathrm{~d}, 6 \mathrm{H}, J=7.6 \mathrm{~Hz}), 7.44-7.42(\mathrm{t}$, $6 \mathrm{H}, J=7.6 \mathrm{~Hz}), 4.83-4.82(\mathrm{~d}, 12 \mathrm{H}, J=4.1 \mathrm{~Hz}) .{ }^{13} \mathrm{C}$ NMR $\left(101 \mathrm{MHz}, \mathrm{DMSO}-d_{6}\right): \delta(\mathrm{ppm})=192.43$, $164.68,137.49,135.83,134.34,133.03,131.97,128.89,127.79,39.01$. HRMS (ESI): $m / z$ calcd for $\mathrm{C}_{60} \mathrm{H}_{48} \mathrm{~N}_{6} \mathrm{O}_{12} \mathrm{Na}^{+}$: 1067.3228; found: 1067.2886 . See Figure $\mathbf{S 3 2}$ for ${ }^{1} \mathrm{H}$ and ${ }^{13} \mathrm{C}$ NMR spectra of 2.

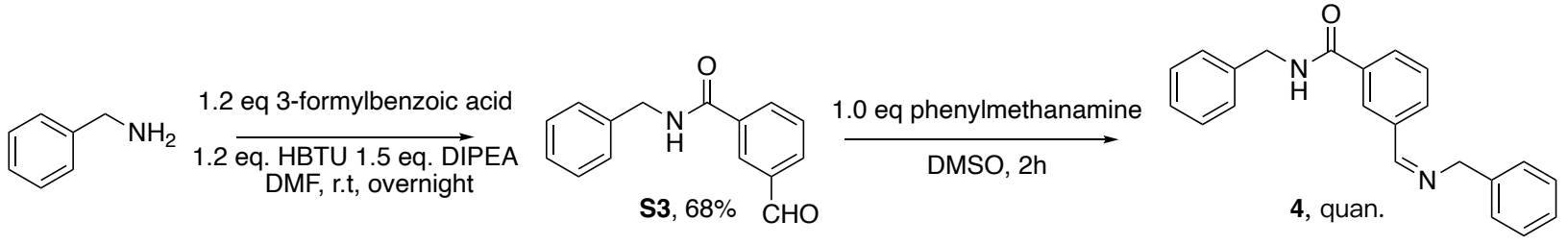

Scheme S2. A scheme describing the preparation of compound 4.

Compound S3: To a solution of phenylmethanamine (102 $\mu \mathrm{L}, 0.93 \mathrm{mmol}), 3$-formylbenzoic acid (168 mg, $1.1 \mathrm{mmol}$ ) and HBTU (425 mg, $1.1 \mathrm{mmol})$ in $2 \mathrm{~mL}$ of dry DMF and DIPEA (248 $\mu \mathrm{L}$, $5.5 \mathrm{mmol}$ ) were added. The reaction mixture was stirred at a room temperature under an atmosphere of nitrogen for one day. Following, $3 \mathrm{~mL}$ of $\mathrm{H}_{2} \mathrm{O}$ was added with the mixture being extracted with EtOAc $(3 \times 5 \mathrm{~mL})$. The organic layer was washed with $\mathrm{H}_{2} \mathrm{O}(3 \times 2 \mathrm{~mL})$, brine $2 \mathrm{~mL}$ and then dried over $\mathrm{Na}_{2} \mathrm{SO}_{4}$. The product was isolated by silica chromatography (hexane: EtOAc $=5: 1)$ as a white solid $(152 \mathrm{mg}, 68 \%) .{ }^{1} \mathrm{H}$ NMR $\left(600 \mathrm{MHz}, \mathrm{CDCl}_{3}\right): \delta(\mathrm{ppm})=10.03(\mathrm{~s}, 1 \mathrm{H}), 8.26$ $(\mathrm{s}, 1 \mathrm{H}), 8.12-8.11(\mathrm{~d}, 1 \mathrm{H}, J=7.7 \mathrm{~Hz}), 8.01-7.99(\mathrm{~d}, 1 \mathrm{H}, J=7.5 \mathrm{~Hz}), 7.63-7.61(\mathrm{t}, 1 \mathrm{H}, J=7.7)$, 7.36-7.31 (m, 5H), 6.66 (broad, $1 \mathrm{H}), 4.67-4.66(\mathrm{~d}, 1 \mathrm{H}, J=5.5 \mathrm{~Hz}) .{ }^{13} \mathrm{C} \mathrm{NMR}\left(151 \mathrm{MHz}, \mathrm{CDCl}_{3}\right)$ : $\delta(\mathrm{ppm})=191.64,166.14,137.89,136.62,135.46,133.25,132.73,129.67,129.01,128.15,127.95$, 127.70, 44.49. HRMS (ESI): $m / z$ calcd for $\mathrm{C}_{15} \mathrm{H}_{13} \mathrm{NO}_{2} \mathrm{Na}^{+}: 262.0844$; found: 262.0831. See Figure S4 for ${ }^{1} \mathrm{H}$ and ${ }^{13} \mathrm{C}$ NMR spectra of $\mathbf{S 3 4}$.

Compound 4: To a solution of $\mathbf{S 3}(5 \mathrm{mg}, 0.021 \mathrm{mmol})$ in $500 \mu \mathrm{L}$ of DMSO- $d_{6}$, phenlymethanamine $(2.29 \mu \mathrm{L}, 0.021 \mathrm{mmol})$ was added. The reaction mixture was stirred at a room temperature for $2 \mathrm{~h}$ to give compound 4. ${ }^{1} \mathrm{H}$ NMR $\left(400 \mathrm{MHz}, \mathrm{DMSO}-d_{6}\right): \delta(\mathrm{ppm})=9.18-9.15(\mathrm{t}$, $1 \mathrm{H}, J=6.0 \mathrm{~Hz}), 8.57(\mathrm{~s}, 1 \mathrm{H}), 8.30(\mathrm{~s}, 1 \mathrm{H}),, 7.99-7.97(\mathrm{~d}, 1 \mathrm{H}, J=7.8 \mathrm{~Hz}), 7.94-7.92(\mathrm{~d}, 1 \mathrm{H}, J=$ $7.7 \mathrm{~Hz}), 7.58-7.54(\mathrm{t}, 1 \mathrm{H}, J=7.7 \mathrm{~Hz}), 7.53-7.22(\mathrm{~m}, 10 \mathrm{H}), 4.8(\mathrm{~s}, 2 \mathrm{H}), 4.49-4.48(\mathrm{~d}, 2 \mathrm{H}, J=6.0$ $\mathrm{Hz}) .{ }^{13} \mathrm{C}$ NMR $\left(101 \mathrm{MHz}, \mathrm{DMSO}-d_{6}\right): \delta(\mathrm{ppm})=165.80,161.33,139.57,139.40,136.16,134.88$, $130.77,129.45,128.81,128.39,128.27,127.99$, 127.24, 126.85, 126.74, 126.57, 63.96, 42.68 . HRMS (ESI): $m / z$ calcd for $\mathrm{C}_{22} \mathrm{H}_{21} \mathrm{~N}_{2} \mathrm{O}^{+}: 329.1654$; found: 329.1651 . See Figure $\mathbf{S 3 5}$ for ${ }^{1} \mathrm{H}$ and ${ }^{13} \mathrm{C}$ NMR spectra of 4 . 

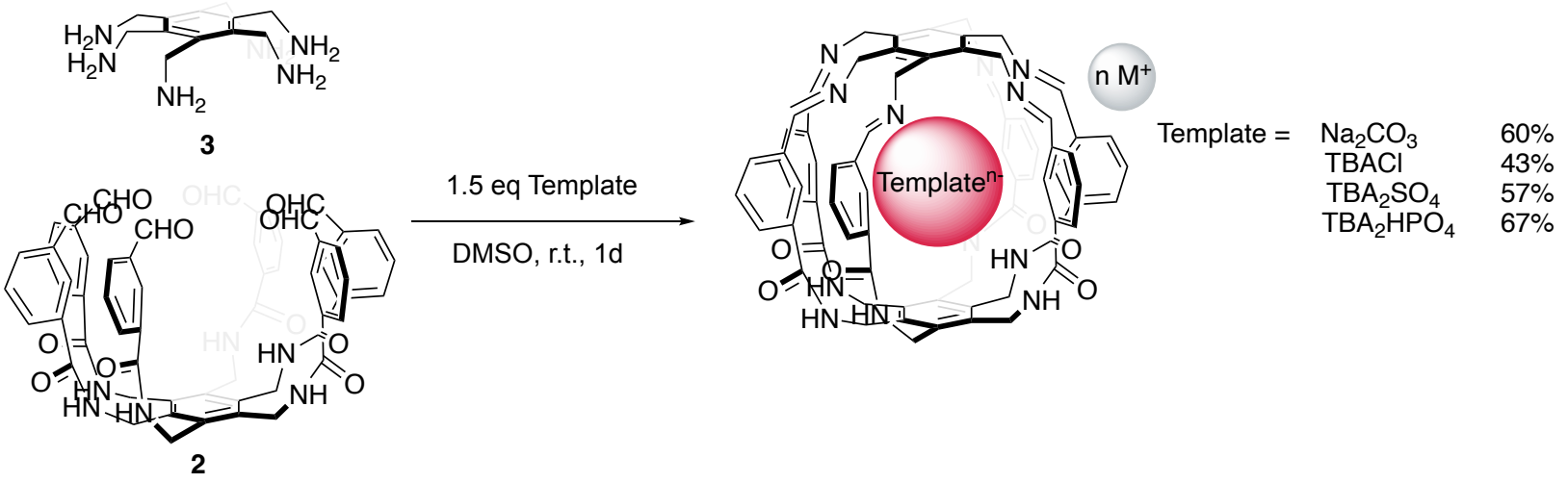

Scheme S3. A synthetic scheme describing the preparation of $\left[\mathrm{CO}_{3} \subset 1\right] \mathbf{N a}_{2},[\mathrm{Cl} \subset \mathbf{1}] \mathrm{TBA}$, $\left[\mathrm{SO}_{4} \subset \mathbf{C}\right] \mathbf{T B A}_{2}$ and $\left[\mathrm{HPO}_{4} \subset \mathbf{1}\right] \mathbf{T B A}_{2}$. The reported yields were obtained from ${ }^{1} \mathrm{H}$ NMR spectra of the reaction mixtures using 1,3,5-trimethoxybenzene as an internal standard.

$\left[\mathrm{CO}_{3} \subset 1\right] \mathrm{Na}_{2}$ : To a solution of compound $3(10 \mathrm{mg}, 0.0096 \mathrm{mmol})$ in $1.25 \mathrm{~mL}$ of DMSO, aqueous $\mathrm{Na}_{2} \mathrm{CO}_{3}(14.4 \mu \mathrm{L}, 1 \mathrm{M})$ and hexa-amine $2(2.41 \mathrm{mg}, 0.0096 \mathrm{mmol}$ in $1.25 \mathrm{~mL}$ DMSO) were added. The reaction mixture was stirred at a room temperature for $24 \mathrm{~h}$. The solution was centrifuged to remove excess of $\mathrm{Na}_{2} \mathrm{CO}_{3}$ followed by the addition of THF: Hexane $=1: 1$ to precipitate $\left[\mathrm{CO}_{3} \subset 1\right] \mathrm{Na}_{2}$ as a white solid $(6.9 \mathrm{mg}, 56 \%) .{ }^{1} \mathrm{H}$ NMR $\left(700 \mathrm{MHz}\right.$, DMSO- $\left.d_{6}\right): \delta(\mathrm{ppm})=11.51(\mathrm{~s}$, $6 \mathrm{H}), 9.33(\mathrm{~s}, 6 \mathrm{H}), 8.20(\mathrm{~s}, 6 \mathrm{H}), 7.60-7.59(\mathrm{~d}, 6 \mathrm{H}, J=8.1 \mathrm{~Hz}), 7.57-7.56(\mathrm{~d}, 6 \mathrm{H}, J=8.3 \mathrm{~Hz}), 7.02-$ $7.00(\mathrm{t}, 6 \mathrm{H}, J=8.0 \mathrm{~Hz}), 4.91(\mathrm{~s}, 12 \mathrm{H}), 4.56(\mathrm{~s}, 12 \mathrm{H}) .{ }^{13} \mathrm{C}$ NMR $\left(176 \mathrm{MHz}\right.$, DMSO- $\left.d_{6}\right): \delta(\mathrm{ppm})$ $=166.87,164.31,159.81,140.24,137.32,135.68,133.92,131.18,130.12,127.54,126.75,56.51$, 40.11. HRMS (ESI): $\mathrm{m} / z$ calcd for $\left[\mathrm{HCO}_{3}+\mathrm{C}_{72} \mathrm{H}_{60} \mathrm{~N}_{12} \mathrm{O}_{6}\right]^{-}: 1249.4679$; found: 1249.4586. See Figures $\mathbf{S 7 - 9}$ for ${ }^{1} \mathrm{H},{ }^{13} \mathrm{C}$, HSQC and HMBC NMR spectra of [COO $\left.\mathbf{O}_{3} \subset \mathbf{1}\right] \mathbf{N a} \mathbf{a}_{2}$; ESI-MS (top) and simulated isotopic pattern (bottom) for $\left[\mathrm{HCO}_{3} \subset 1\right]^{-}$are shown below.

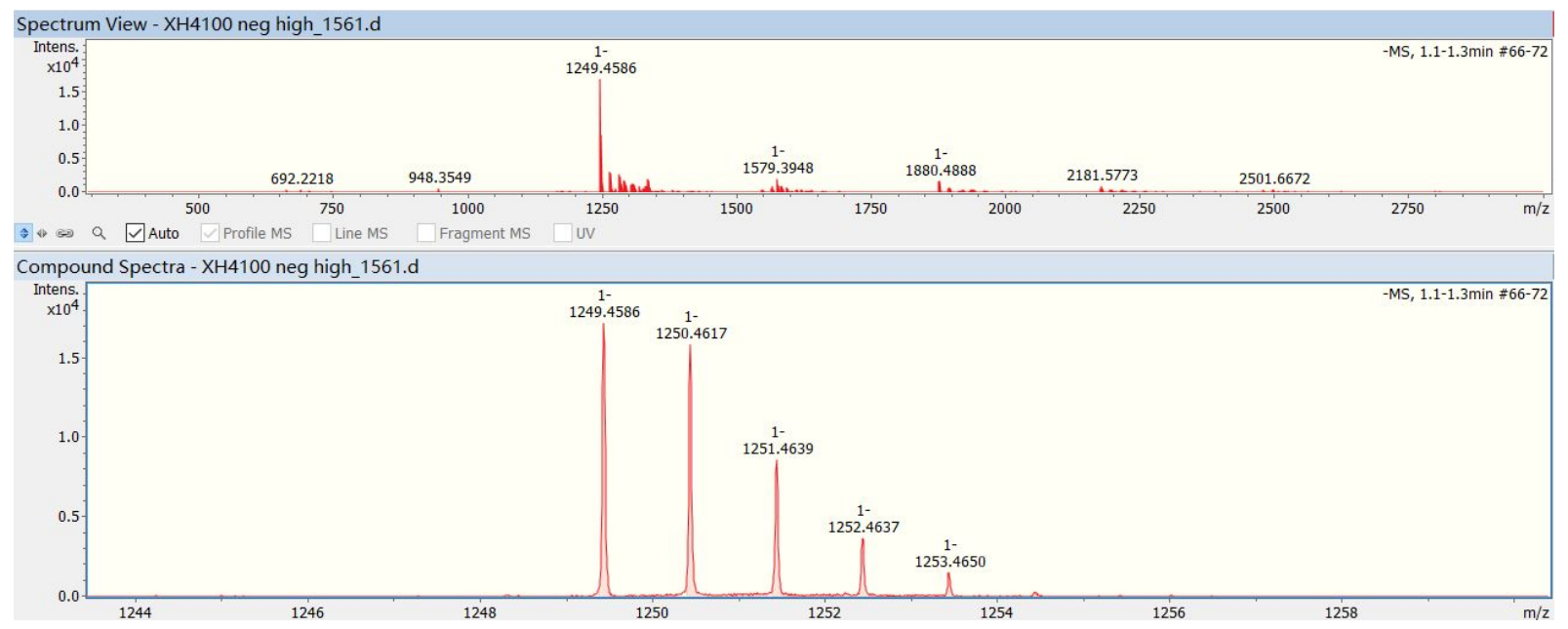




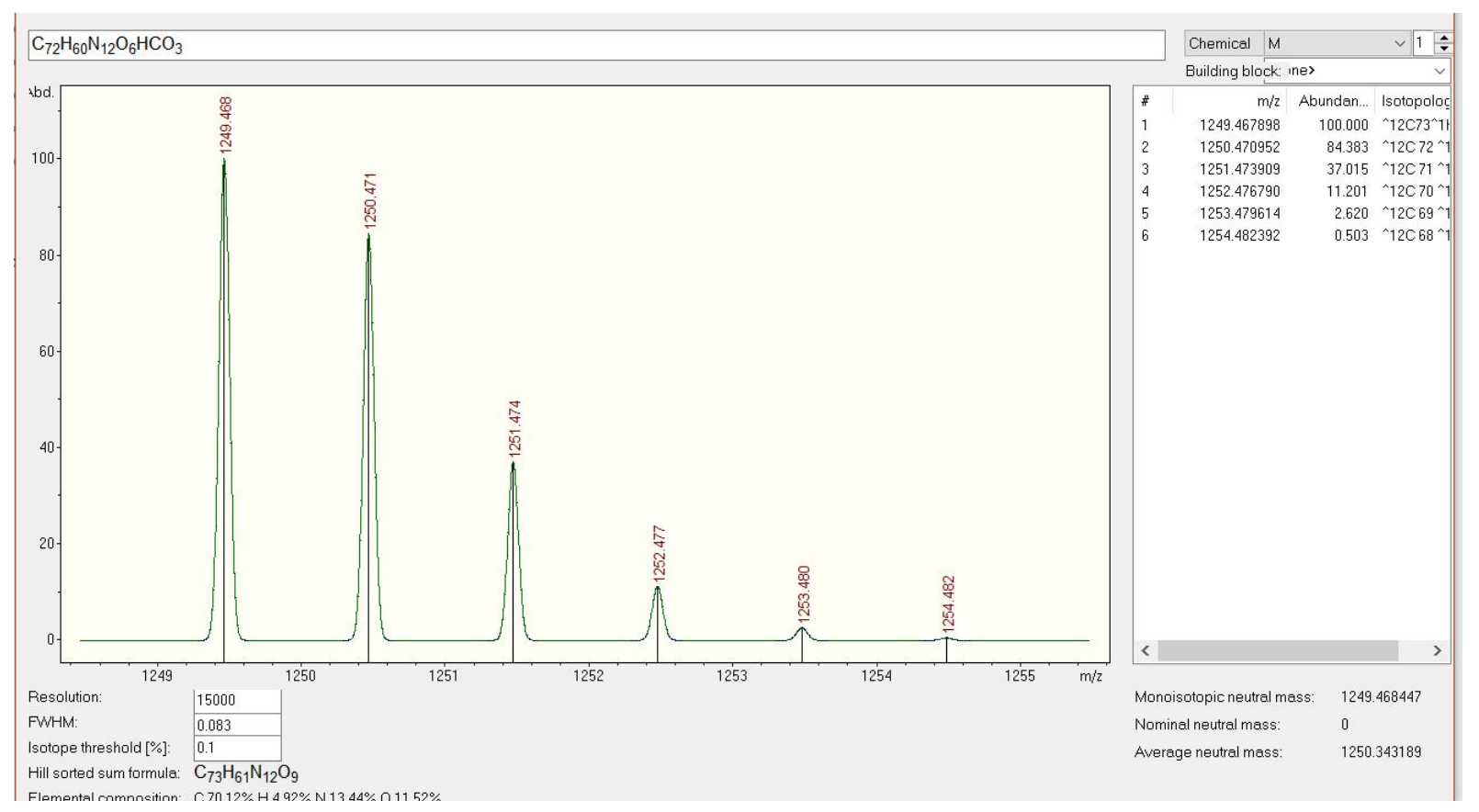

[ClС1]TBA: To a solution of $\mathbf{3}(10 \mathrm{mg}, 0.0096 \mathrm{mmol})$ in $1.25 \mathrm{~mL}$ of DMSO, TBACl $(28.8 \mu \mathrm{L}$, $500 \mathrm{mM}$ in DMSO) and $2(2.41 \mathrm{mg}, 0.0096 \mathrm{mmol}$ in $1.25 \mathrm{~mL}$ DMSO $)$ were added. The reaction mixture was stirred at a room temperature for $24 \mathrm{~h}$. Following, the solvent was removed by blowing nitrogen gas over it. The crude product was dissolved in $5 \mathrm{~mL}$ of $\mathrm{CH}_{2} \mathrm{Cl}_{2}$ followed by centrifugation to remove oligomeric impurities. Finally, $25 \mathrm{~mL}$ of hexane was added to trigger the

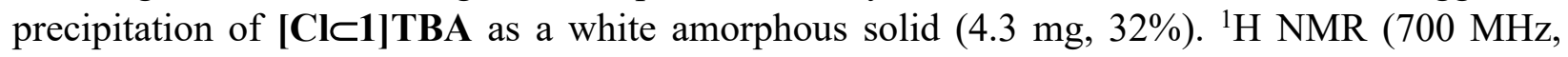
DMSO-d $)): \delta(\mathrm{ppm})=8.18(\mathrm{~s}, 6 \mathrm{H}), 8.13$. (t, $6 \mathrm{H}, J=8.0 \mathrm{~Hz}), 8.10(\mathrm{~s}, 6 \mathrm{H}), 7.58-7.56(\mathrm{~d}, 6 \mathrm{H}, J=$ $8.1 \mathrm{~Hz}), 7.56-7.55(\mathrm{~d}, 6 \mathrm{H}, J=8.3 \mathrm{~Hz}), 7.07-7.07(\mathrm{t}, 6 \mathrm{H}, J=8.0 \mathrm{~Hz}), 5.00(\mathrm{~s}, 12 \mathrm{H}), 4.72-4.72(\mathrm{~d}$, $12 \mathrm{H}, J=8.1 \mathrm{~Hz}), 3.18-3.15(\mathrm{~m}, 8 \mathrm{H}), 1.58-1.54(\mathrm{~m}, 8 \mathrm{H}), 1.35-1.30(\mathrm{~m}, 8 \mathrm{H}), 0.95-0.93(\mathrm{t}, 12 \mathrm{H}, J=$ $8.1 \mathrm{~Hz}) .{ }^{13} \mathrm{C}$ NMR $\left(176 \mathrm{MHz}, \mathrm{DMSO}-d_{6}\right): \delta(\mathrm{ppm})=164.32,160.43,139.39,137.51,135.99$, $133.12,129.85,57.99,56.49,39.73,23.53,19.68,13.97$. HRMS (ESI): $\mathrm{m} / z$ calcd for $\left[\mathrm{C}_{72} \mathrm{H}_{60} \mathrm{~N}_{12} \mathrm{O}_{6} \mathrm{Cl}\right]^{-}:$: 1223.4442; found: 1223.4448 . See Figures $\mathbf{S 2 0 - 2 3}$ for ${ }^{1} \mathrm{H},{ }^{13} \mathrm{C}, \mathrm{HSQC}, \mathrm{HMBC}$ and NOESY NMR spectra of [Clс1]TBA. ESI-MS (top) and simulated isotopic pattern (bottom) for $[\mathbf{C l} \subset \mathbf{1}]^{-}$are shown below.

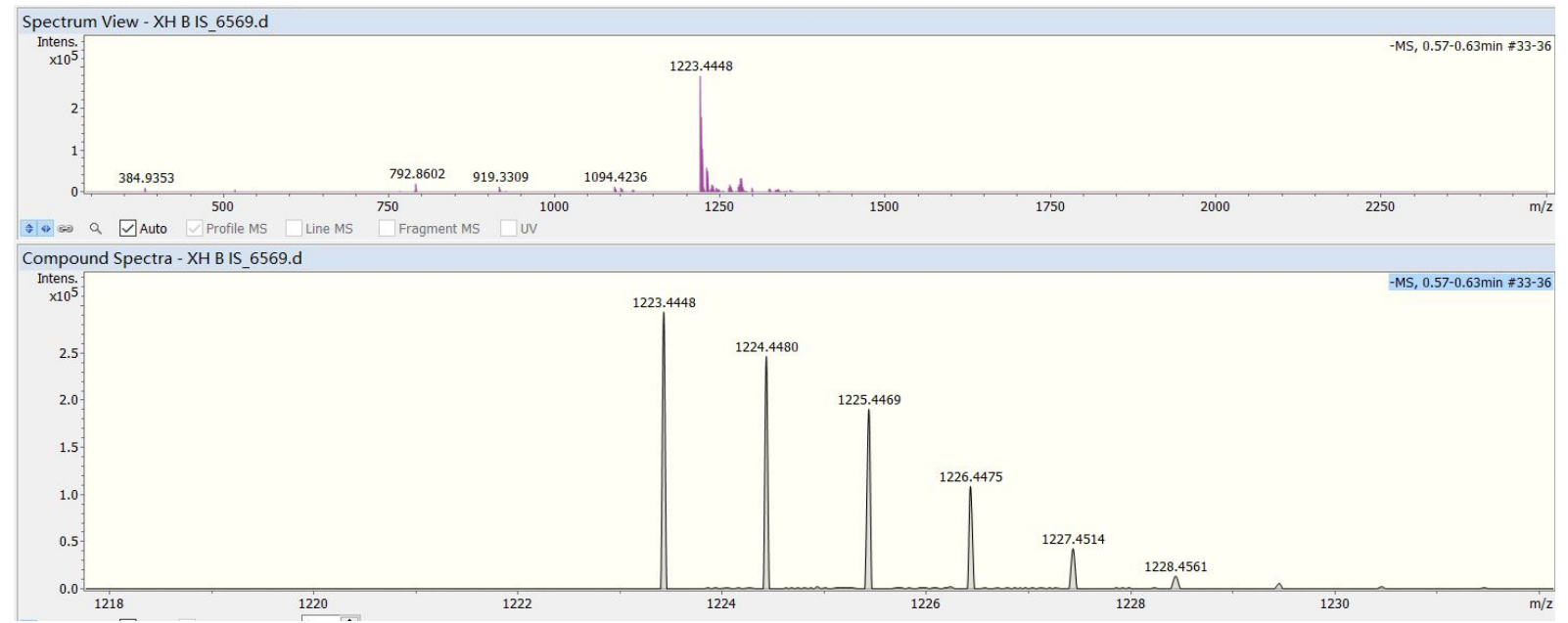




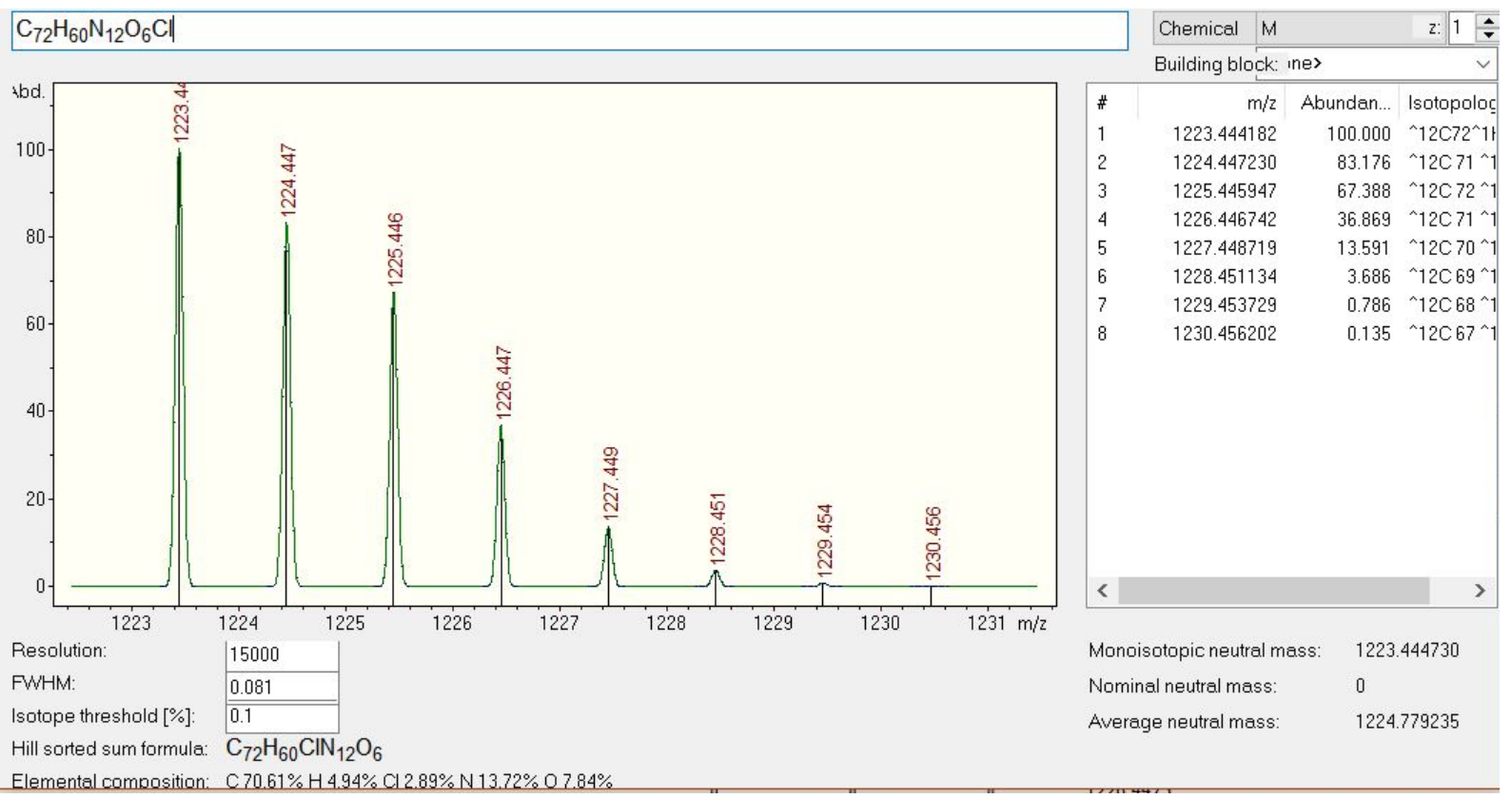

[SO $\mathbf{S O}_{4} \subset \mathbf{1 ]}$ TBA 2 : To a solution of $3(6 \mathrm{mg}, 0.0096 \mathrm{mmol})$ in $0.75 \mathrm{~mL}$ of DMSO, $\mathrm{TBAHSO}_{4}(17.2$ $\mu \mathrm{L}, 500 \mathrm{mM}$ in DMSO), TBAOH $\left(4.3 \mu \mathrm{L}, 40 \mathrm{wt} \%\right.$ in $\left.\mathrm{H}_{2} \mathrm{O}\right)$ and 2 (1.44 $\mathrm{mg}, 0.0096 \mathrm{mmol}$ in 0.75 $\mathrm{mL}$ DMSO) were added. The reaction mixture was stirred at a room temperature for $24 \mathrm{~h}$. Crude [SO $\left.\mathbf{S O}_{4} \subset \mathbf{1}\right] \mathbf{T B} \mathbf{A}_{2}$ was then precipitated by addition of $20 \mathrm{~mL}$ of toluene: $\mathrm{Et}_{2} \mathrm{O}=1: 3$. The white amorphous solid could be further purified by dissolving it in $1 \mathrm{~mL}$ of $\mathrm{CH}_{3} \mathrm{OH}$ and then precipitation with $5 \mathrm{~mL}$ of $\mathrm{Et}_{2} \mathrm{O}(4.9 \mathrm{mg}, 48 \%) .{ }^{1} \mathrm{H}$ NMR $\left(700 \mathrm{MHz}, \mathrm{DMSO}-d_{6}\right): \delta(\mathrm{ppm})=9.66(\mathrm{~s}, 6 \mathrm{H}), 9.09$ $(\mathrm{s}, 6 \mathrm{H}), 8.70(\mathrm{~s}, 6 \mathrm{H}), 7.58-7.57(\mathrm{~d}, 6 \mathrm{H}, J=8.1 \mathrm{~Hz}), 7.54-7.52(\mathrm{~d}, 6 \mathrm{H}, J=8.3 \mathrm{~Hz}), 7.02-6.98(\mathrm{t}, 6 \mathrm{H}$, $J=8.0 \mathrm{~Hz}), 4.88(\mathrm{~s}, 12 \mathrm{H}), 4.60(\mathrm{~s}, 12 \mathrm{H}), 3.18-3.15(\mathrm{~m}, 16 \mathrm{H}), 1.58-1.54(\mathrm{~m}, 16 \mathrm{H}), 1.35-1.30(\mathrm{~m}$, $16 \mathrm{H}), 0.95-0.93(\mathrm{t}, 24 \mathrm{H}, J=8.1 \mathrm{~Hz}) .{ }^{13} \mathrm{C} \mathrm{NMR}\left(176 \mathrm{MHz}, \mathrm{DMSO}-d_{6}\right): \delta(\mathrm{ppm})=164.35,161.35$, 140.55, 137.77, 136.61, 133.27, 130.73, 129.51, 127.71, 126.68, 57.99, 56.91, 39.75, 23.53, 19.68, 13.97. HRMS (ESI): $m / z$ calcd for $\left[\mathrm{SO}_{4}+\mathrm{C}_{72} \mathrm{H}_{60} \mathrm{~N}_{12} \mathrm{O}_{6}\right]^{2-}: 642.2133$; found: 642.2134. See Figures S11-14 for ${ }^{1} \mathrm{H},{ }^{13} \mathrm{C}$, HSQC, HMBC, NOESY NMR spectra of [SO $4 \subset \mathbf{C 1}$ TBA2. ESI-MS (top) and simulated isotopic pattern (bottom) for $\left[\mathbf{S O}_{4} \subset \mathbf{1}\right]^{2-}$ are shown below.

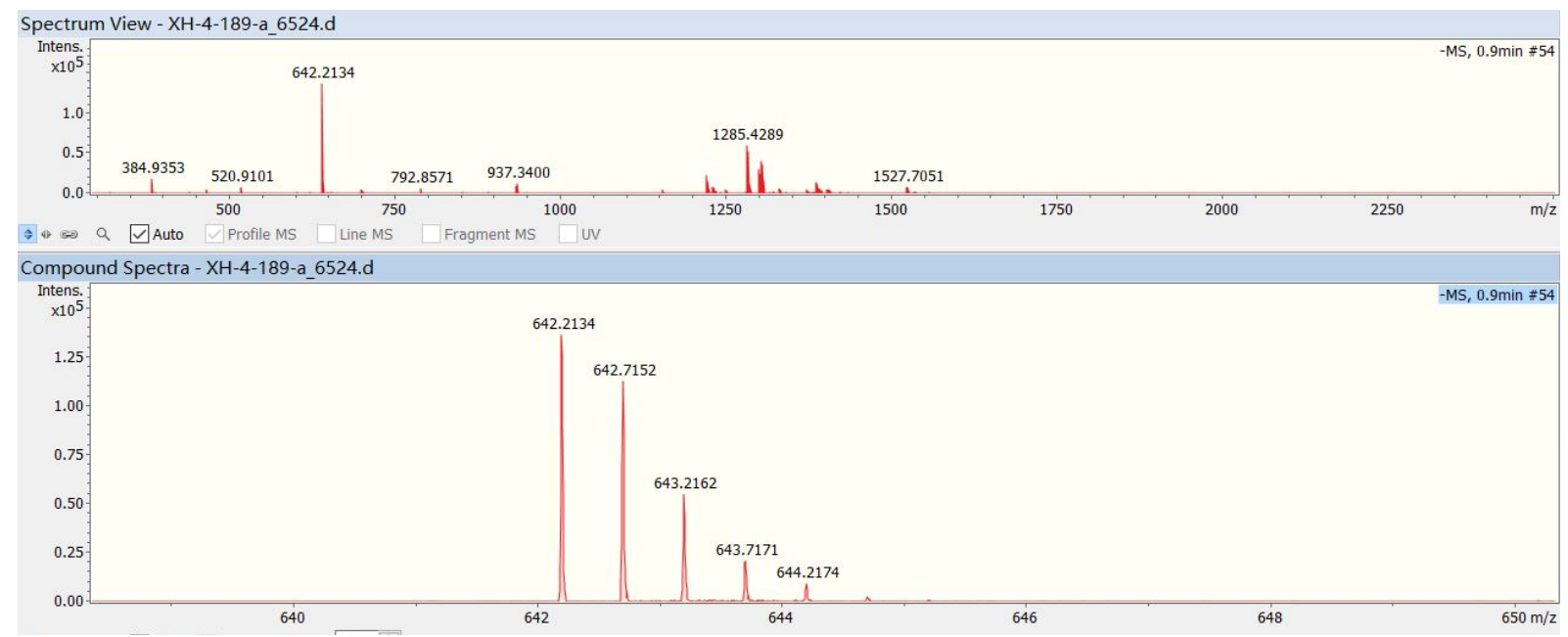




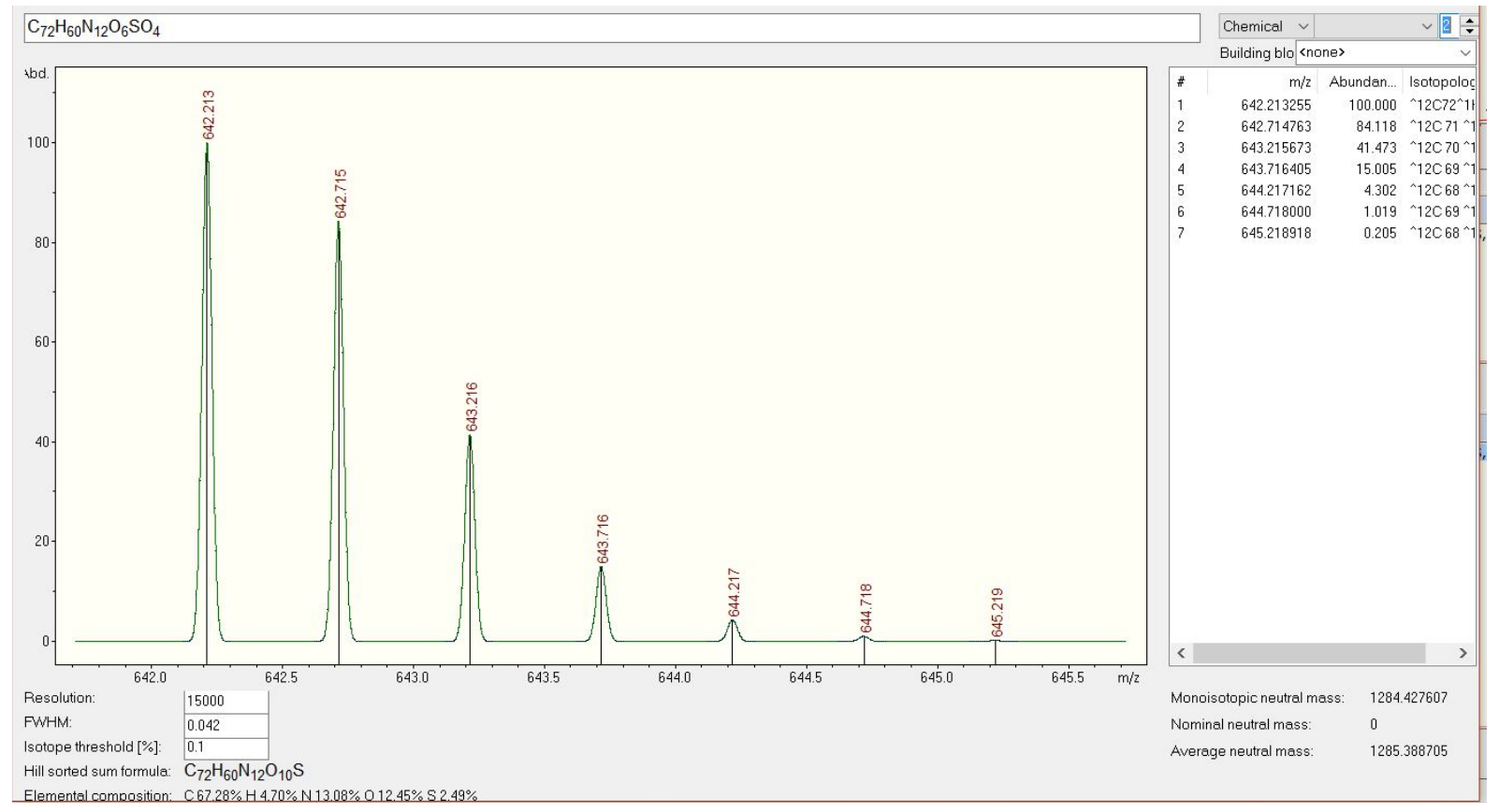

[HPO 4 -1]TBA $\mathbf{A}_{2}$ : To a solution of $3(6 \mathrm{mg}, 0.0096 \mathrm{mmol})$ in $0.75 \mathrm{~mL}$ of DMSO, $\mathrm{TBAH}_{2} \mathrm{PO}_{4}(17.2$ $\mu \mathrm{L}, 500 \mathrm{mM}$ in DMSO), TBAOH $\left(4.3 \mu \mathrm{L}, 40 \mathrm{wt} \%\right.$ in $\left.\mathrm{H}_{2} \mathrm{O}\right)$ and 2 (1.44 $\mathrm{mg}, 0.0096 \mathrm{mmol}$ in 0.75 $\mathrm{mL}$ DMSO) were added in one portion. The reaction mixture was stirred, at a room temperature, for $24 \mathrm{~h}$. Crude $\left[\mathbf{H P O}_{4} \subset \mathbf{1}\right] \mathbf{T B \mathbf { A } _ { 2 }}$ was then precipitated by addition of $20 \mathrm{~mL}$ of toluene: $\mathrm{Et}_{2} \mathrm{O}=$ 1:3. The white amorphous solid could be further purified by dissolving it in $1 \mathrm{~mL}$ of $\mathrm{CH}_{3} \mathrm{OH}$ and then precipitation with $5 \mathrm{~mL}$ of $\mathrm{Et}_{2} \mathrm{O}(5.6 \mathrm{mg}, 55 \%) .{ }^{1} \mathrm{H}$ NMR $\left(700 \mathrm{MHz}, \mathrm{DMSO}-d_{6}\right): \delta(\mathrm{ppm})=$ $11.34(\mathrm{~s}, 6 \mathrm{H}), 9.29$ (s, 6H), $8.43(\mathrm{~s}, 6 \mathrm{H}), 7.56-7.55(\mathrm{~d}, 6 \mathrm{H}, J=8.1 \mathrm{~Hz}), 7.45-7.44$ (d, $6 \mathrm{H}, J=8.3$ $\mathrm{Hz}), 6.98-6.95(\mathrm{t}, 6 \mathrm{H}, J=8.0 \mathrm{~Hz}), 4.91(\mathrm{~s}, 12 \mathrm{H}), 4.56(\mathrm{~d}, 12 \mathrm{H}, J=8.1 \mathrm{~Hz})$, , 4.21-4.20 (d, $1 \mathrm{H}, J=$ $8.1 \mathrm{~Hz}), 3.18-3.15(\mathrm{~m}, 16 \mathrm{H}), 1.58-1.54(\mathrm{~m}, 16 \mathrm{H}), 1.35-1.30(\mathrm{~m}, 16 \mathrm{H}), 0.95-0.93(\mathrm{t}, 24 \mathrm{H}, J=8.1$ $\mathrm{Hz}) .{ }^{13} \mathrm{C}$ NMR $\left(176 \mathrm{MHz}, \mathrm{DMSO}-d_{6}\right): \delta(\mathrm{ppm})=164.44,162.60,140.15,137.38,136.03,134.00$, 130.42, 129.90, 127.78, 127.30, 57.99, 57.36, 39.90, 23.53, 19.68, 13.97 HRMS (ESI): $\mathrm{m} / z \mathrm{calcd}$ for $\left[\mathrm{H}_{2} \mathrm{PO}_{4}+\mathrm{C}_{72} \mathrm{H}_{60} \mathrm{~N}_{12} \mathrm{O}_{6}\right]^{-}$: 1285.4444; found: 1285.4393 . See Figures $\mathbf{S 1 5 - 1 9}$ for ${ }^{1} \mathrm{H},{ }^{13} \mathrm{C},{ }^{31} \mathrm{P}$, HSQC, ${ }^{1} \mathrm{H}_{-}{ }^{13} \mathrm{C}$ HMBC, ${ }^{1} \mathrm{H}_{-}{ }^{31} \mathrm{P}$ HMBC and NOESY NMR spectra of [HPO $\left.\mathbf{H}_{4} \subset \mathbf{1}\right]$ TBA $\mathbf{2}$; ESI-MS (top) and simulated isotopic pattern (bottom) for $\left[\mathbf{H}_{2} \mathbf{P O}_{4} \subset \mathbf{l}\right]^{-}$are shown below.

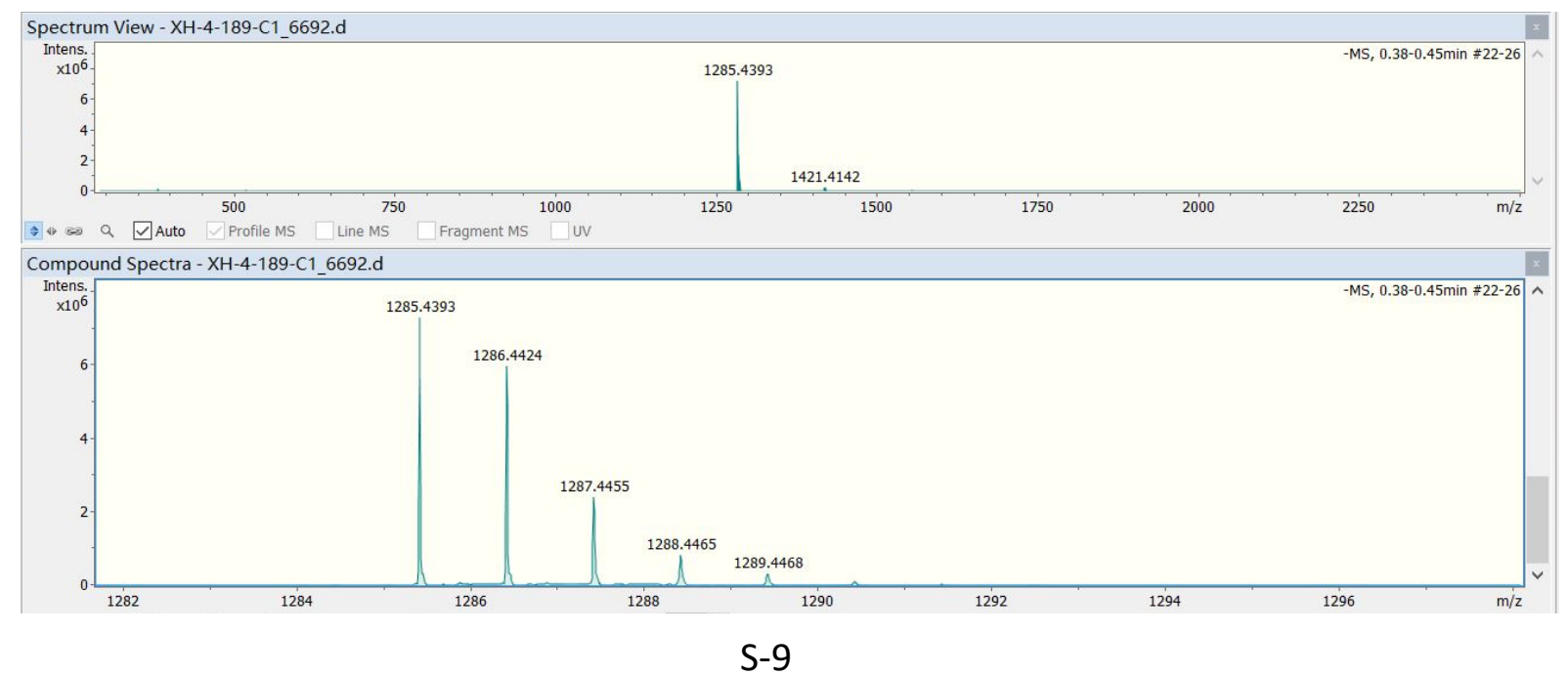




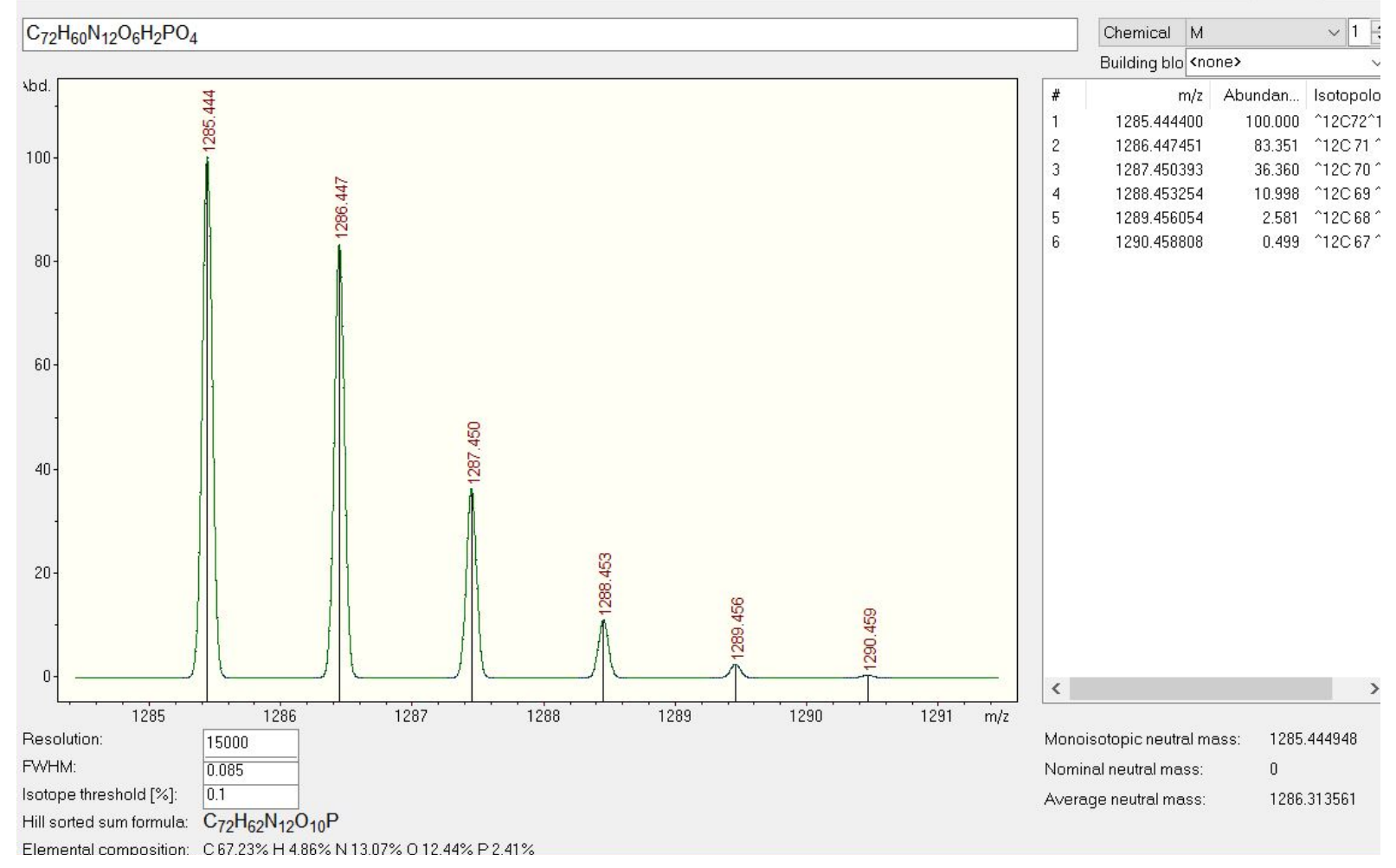




\section{Spectroscopic Experiments}

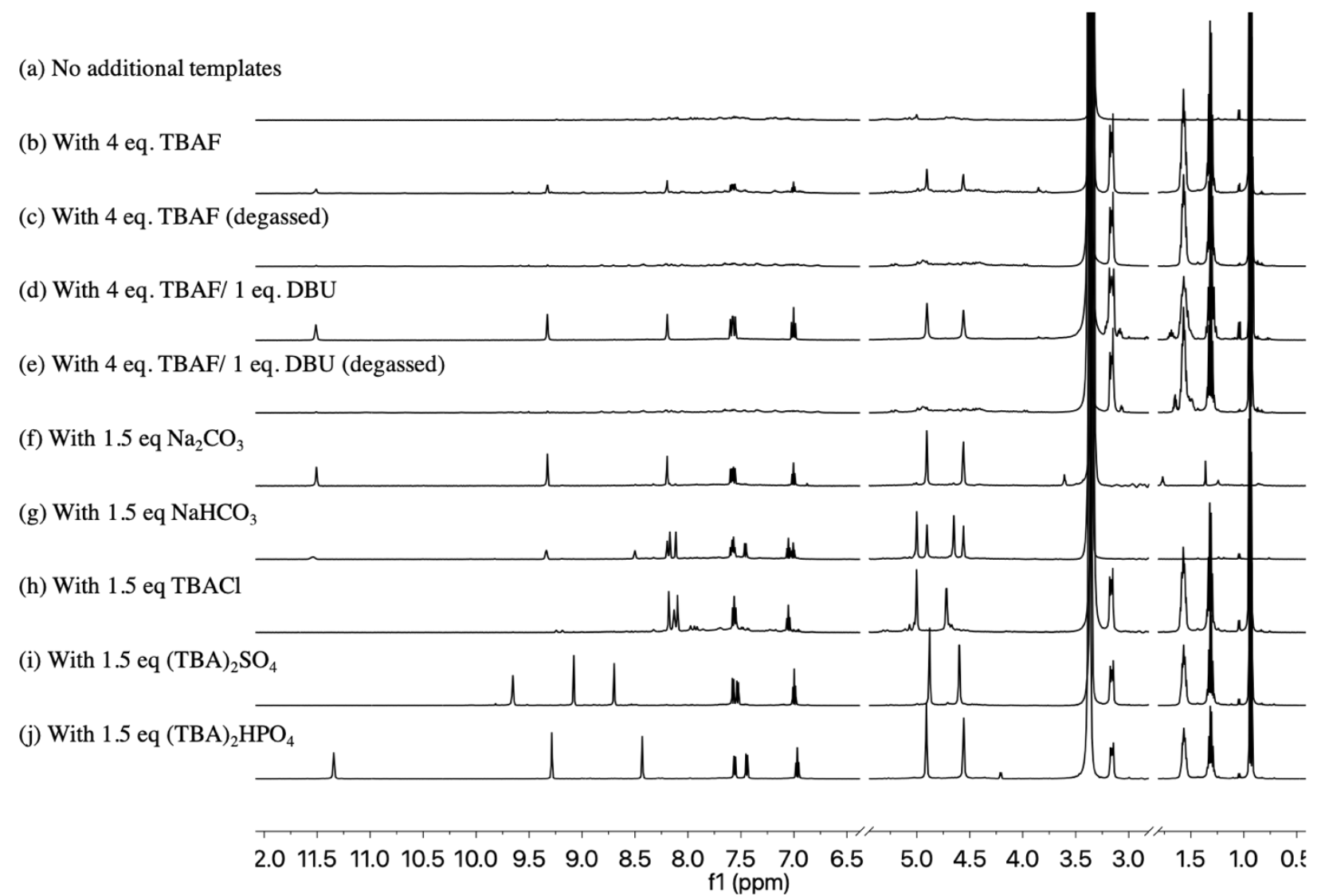

Figure S1. ${ }^{1} \mathrm{H}$ NMR spectra $(600 \mathrm{MHz}, 298 \mathrm{~K})$ of $500 \mu \mathrm{L}$ solution of DMSO $(90 \%$ DMSO and $10 \%$ DMSO- $\left.d_{6}\right)$ containing compound $3(2 \mathrm{mg}, 0.0019 \mathrm{mmol})$ and hexa-amine $2(0.48 \mathrm{mg}, 0.0019$ mmol) with and without template (specified on top of each spectrum). All spectra were obtained after mixing all of the components at a room temperature in a closed vial and then stirring them for $24 \mathrm{~h}$. 


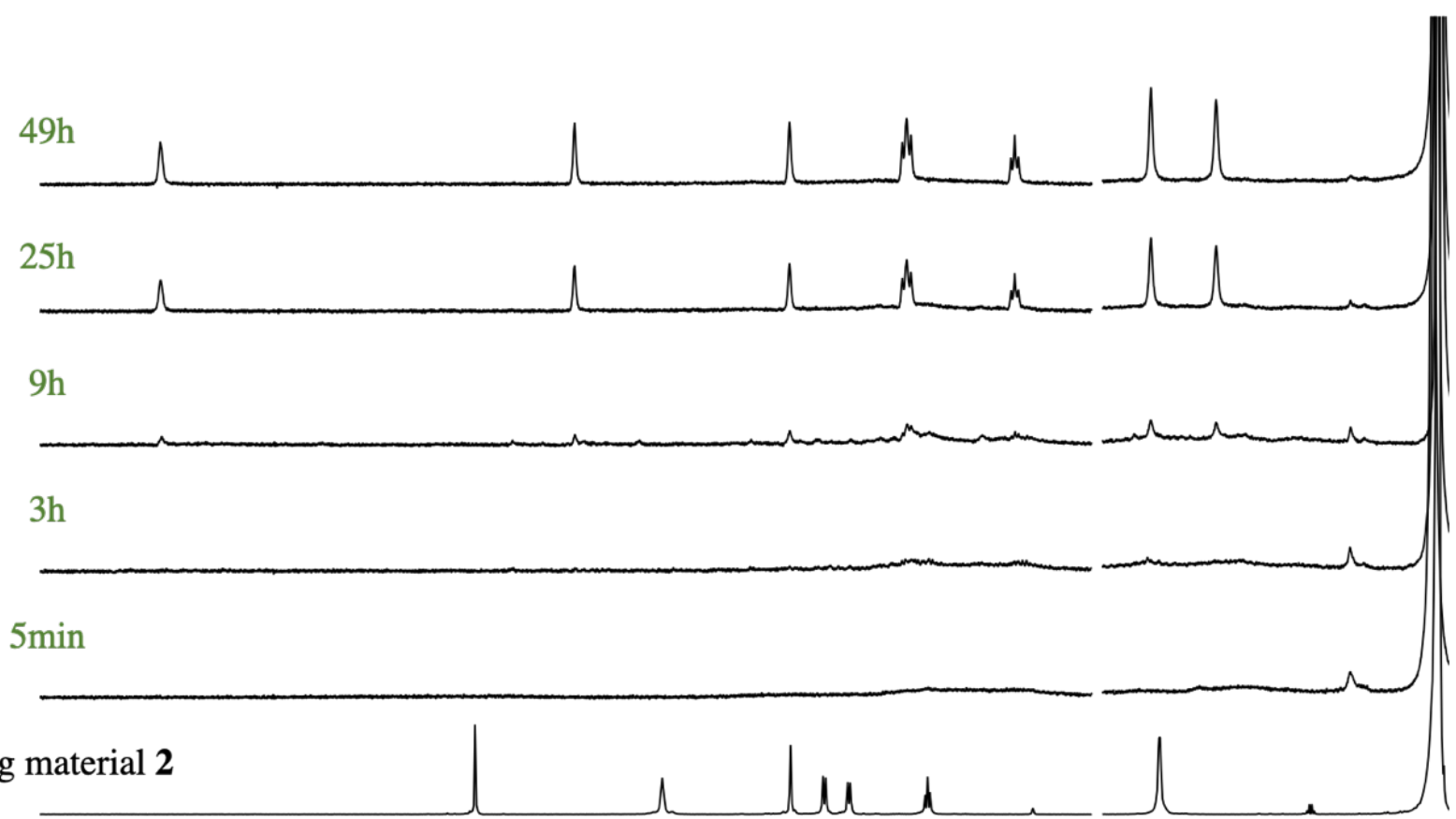

Starting material $\mathbf{3}$

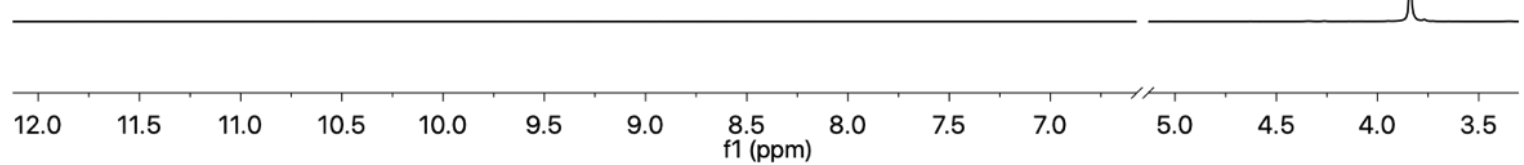

Figure S2. ${ }^{1} \mathrm{H}$ NMR spectra (400 MHz, 298K) obtained in the condensation of $2(0.0095 \mathrm{mmol})$ and $3(0.0095 \mathrm{mmol})$ in $2.5 \mathrm{~mL}$ of DMSO/DMSO- $d_{6}$ containing TBAF $(0.038 \mathrm{mmol})$ and DBU (0.0095 mmol). 
(A)Purified [anion $\left.{ }_{\mathrm{x}} \subset 1\right]^{\mathrm{TB}} \mathrm{A}_{\mathrm{y}}$

(B) $\left[\operatorname{anion}_{\mathrm{x}} \subset 1\right] \mathrm{TBA}_{\mathrm{y}}$ with 1 eq.

Internal standard

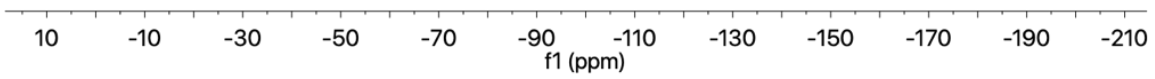

Figure S3. ${ }^{19} \mathrm{~F}$ NMR spectra $(565 \mathrm{MHz}, 298 \mathrm{~K})$ obtained in the condensation of $2(0.0019 \mathrm{mmol})$ and $3(0.0019 \mathrm{mmol})$ in $500 \mu \mathrm{L}$ of DMSO/DMSO- $d_{6}$ containing TBAF $(0.0077 \mathrm{mmol})$ and DBU $(0.0019 \mathrm{mmol})$. (A) The product of the reaction was precipitated using $10 \mathrm{~mL}$ of 1:1 THF/hexane. The solid isolated by centrifugation was then washed twice with $2 \mathrm{~mL}$ of THF to be dissolved in $d_{6}$-DMSO for analysis. (B) To the sample in (A), one molar equivalent of trifluorotoluene was added as an internal standard.

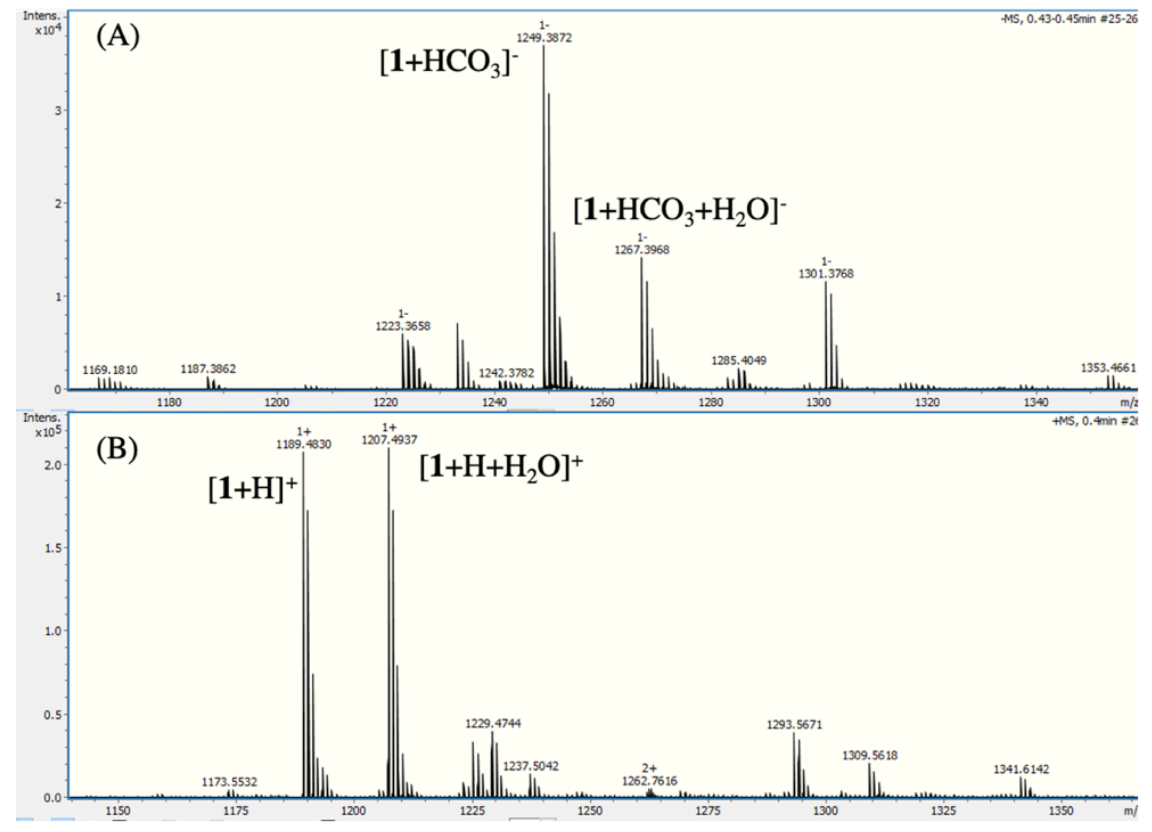

Figure S4. ESI-MS of the solution obtained from experiment described in Figure S2 by using (A) negative (B) positive modes of acquisition. With the negative mode (A), one can observe the formation of $\left[\mathrm{HCO}_{3} \subset \mathbf{1}\right]^{-}$, while the positive mode $(\mathrm{B})$ suggests the existence of $(\mathbf{1}+\mathbf{H})^{+}$ion. 


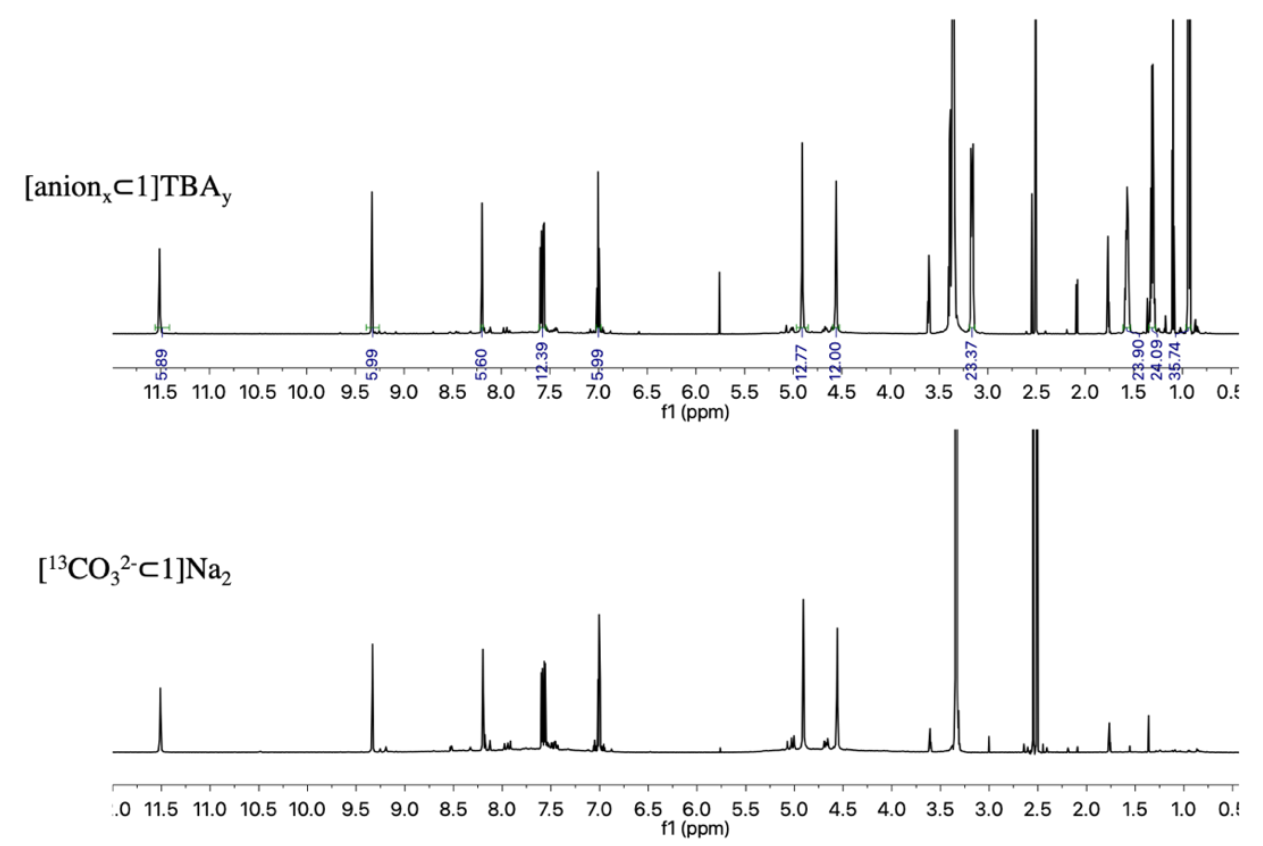

Figure S5. ${ }^{1} \mathrm{H}$ NMR spectra (700 MHz, 298K) obtained in the condensation of $2(0.0019 \mathrm{mmol})$ and $3(0.0019 \mathrm{mmol})$ in $500 \mu \mathrm{L}$ of DMSO (see Figure S1 for further experimental details) with (top) TBAF (0.0077 mmol)/DBU (0.0019 mmol) and (bottom) $\mathrm{Na}_{2}{ }^{13} \mathrm{CO}_{3}(0.0029 \mathrm{mmol})$ used as templates.

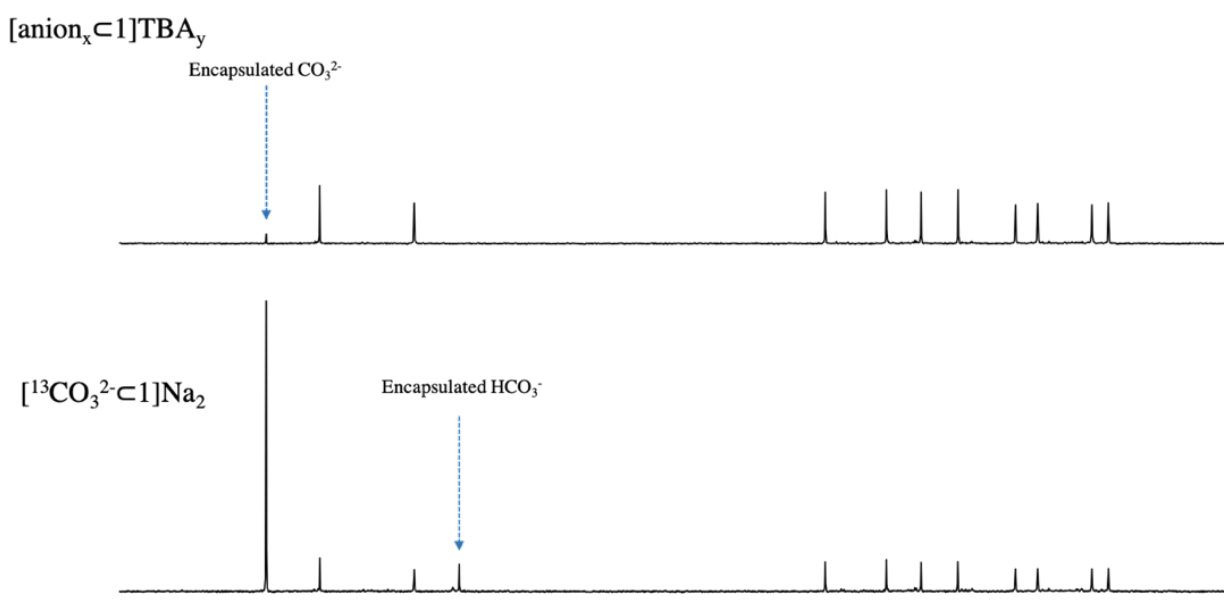

$\begin{array}{lllllllllllllllllllllllllll}172 & 170 & 168 & 166 & 164 & 162 & 160 & 158 & 156 & 154 & 152 & 150 & 148 & 146 & 144 & 142 & 140 & 138 & 136 & 134 & 132 & 130 & 128 & 126 & 124 & 122\end{array}$

Figure S6. ${ }^{13} \mathrm{C}$ NMR spectra (176 MHz, 298K) of products of the condensation of $2(0.0019 \mathrm{mmol})$ and $3(0.0019 \mathrm{mmol})$ in $500 \mu \mathrm{L}$ of DMSO (see Figure S3 for further experimental details) with (top) TBAF (0.0077 mmol)/DBU (0.0019 mmol) and (bottom) $\mathrm{Na}_{2}{ }^{13} \mathrm{CO}_{3}(0.0029 \mathrm{mmol})$ used as templates. 


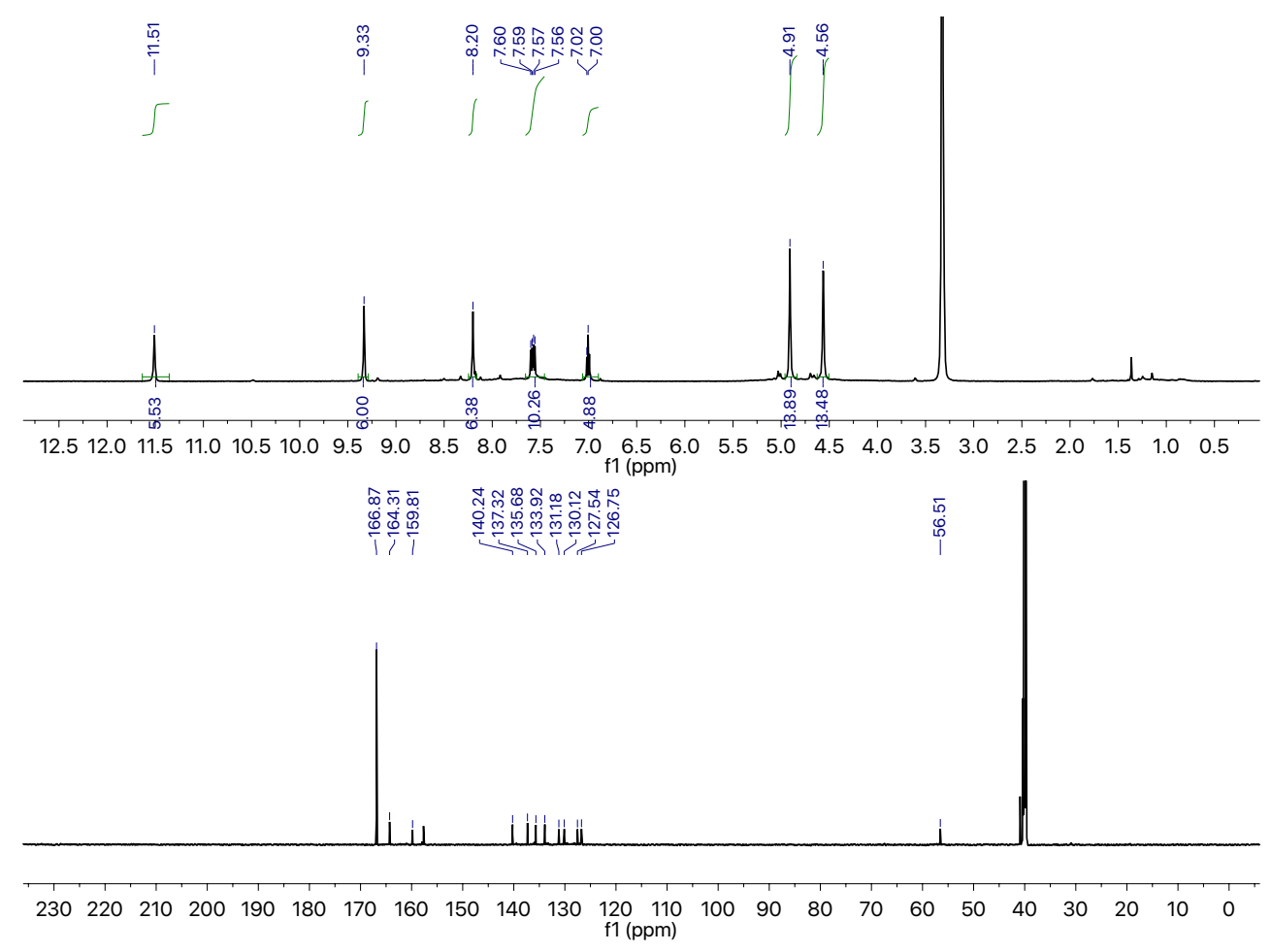

Figure S7. (Top) ${ }^{1} \mathrm{H}$ NMR spectrum $(700 \mathrm{MHz}, 298 \mathrm{~K})$ of $\left[{ }^{13} \mathbf{C O}_{\mathbf{3}} \subset \mathbf{1}\right] \mathbf{N a}_{2}$ in DMSO-d . (Bottom) ${ }^{13} \mathrm{C}$ NMR spectrum $(176 \mathrm{MHz}, 298 \mathrm{~K})$ of $\left[{ }^{\mathbf{1 3}} \mathbf{C O}_{\mathbf{3}} \subset \mathbf{1}\right] \mathbf{N a} \mathbf{a}_{2}$ in DMSO- $d_{6}$.

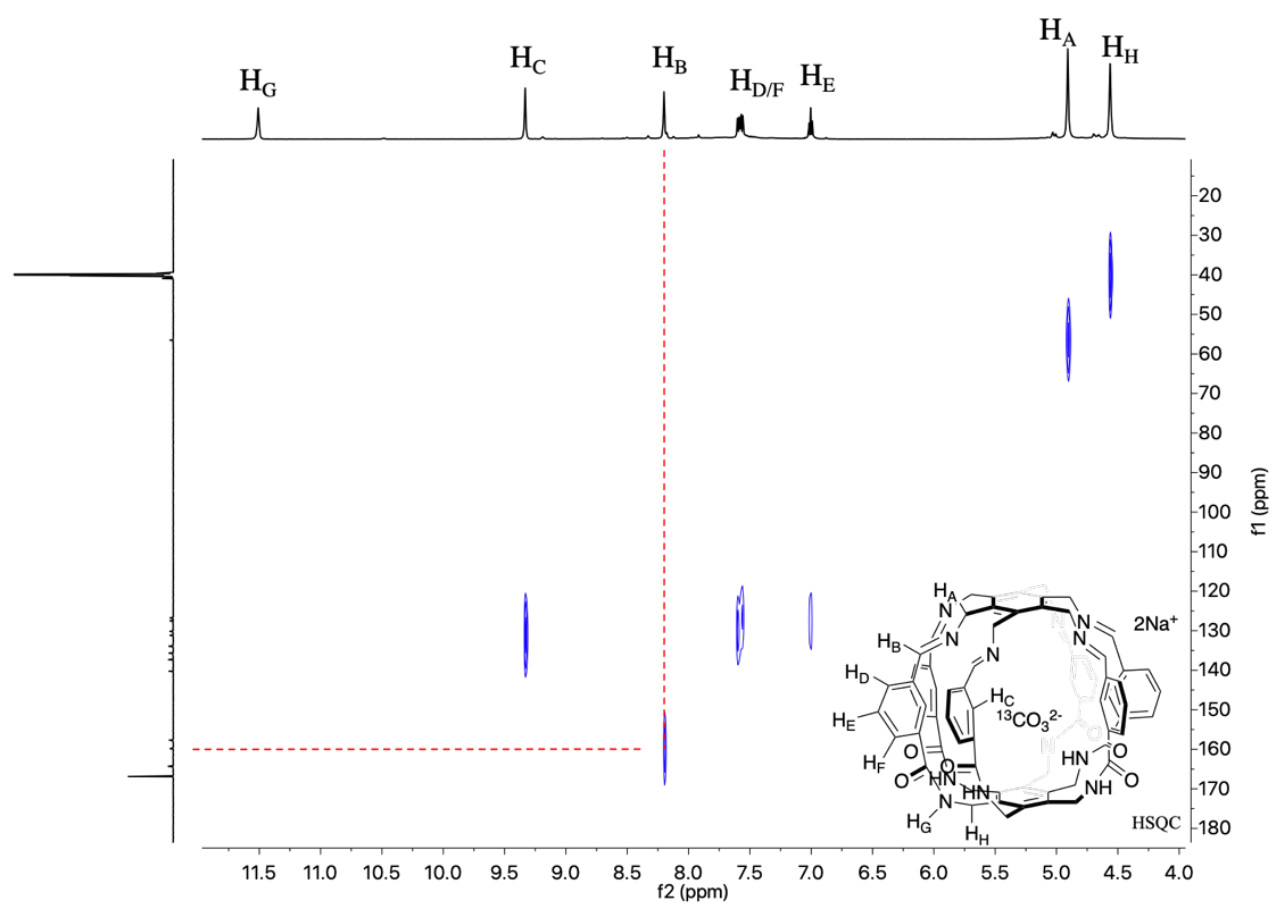

Figure S8. ${ }^{1} \mathrm{H}_{-}{ }^{13} \mathrm{C}$ HSQC NMR spectrum $(700 \mathrm{MHz}, 298 \mathrm{~K})$ of $\left[{ }^{13} \mathbf{C O}_{\mathbf{3}} \subset \mathbf{1}\right] \mathbf{N a}_{2}$ in DMSO- $d_{6}$. 


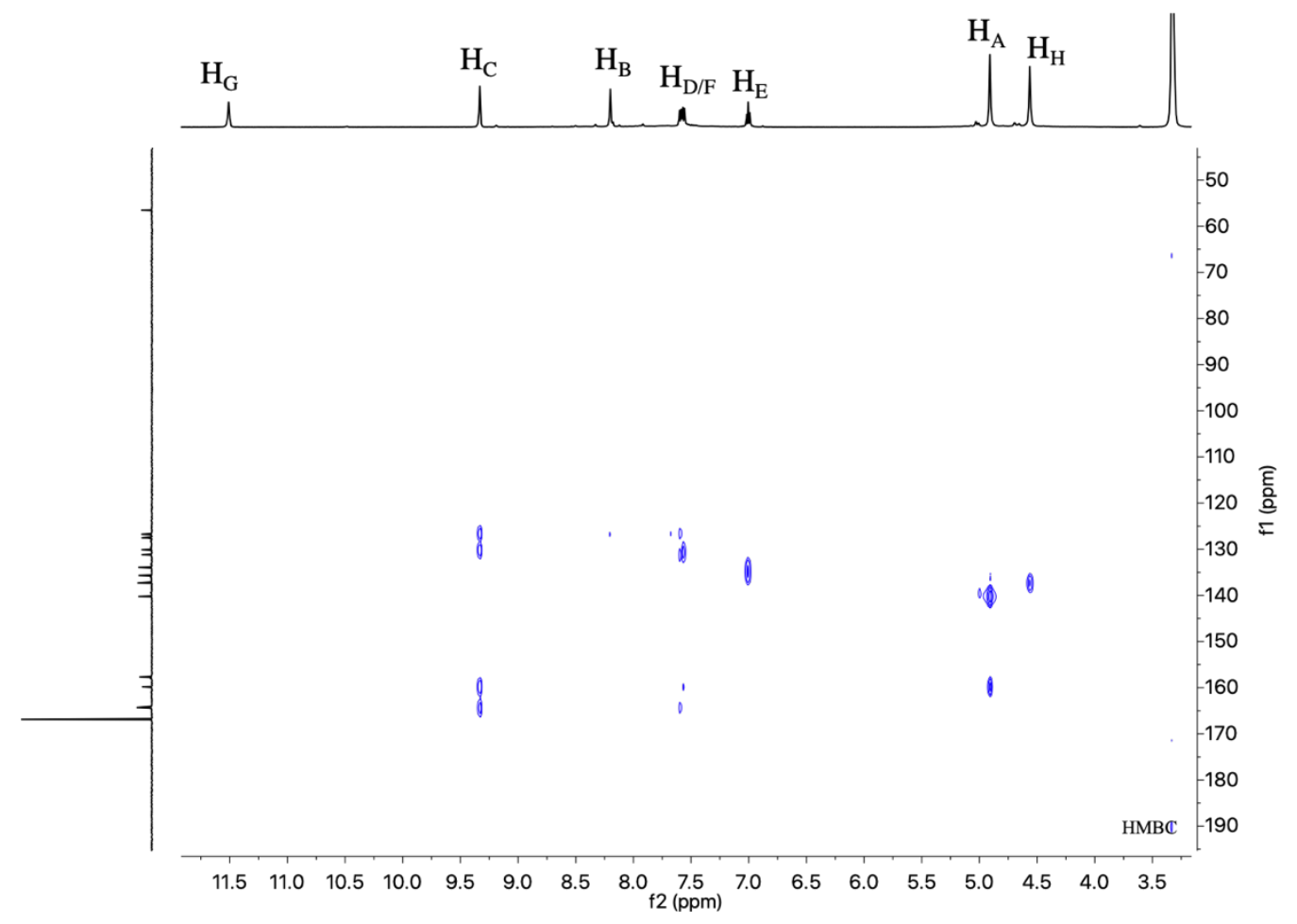

Figure S9. ${ }^{1} \mathrm{H}_{-}{ }^{13} \mathrm{C}$ HMBC NMR spectrum $(700 \mathrm{MHz}, 298 \mathrm{~K})$ of $\left[{ }^{13} \mathbf{C O}_{\mathbf{3}} \subset \mathbf{1}\right] \mathbf{N a}_{2}$ in DMSO- $d_{6}$. 

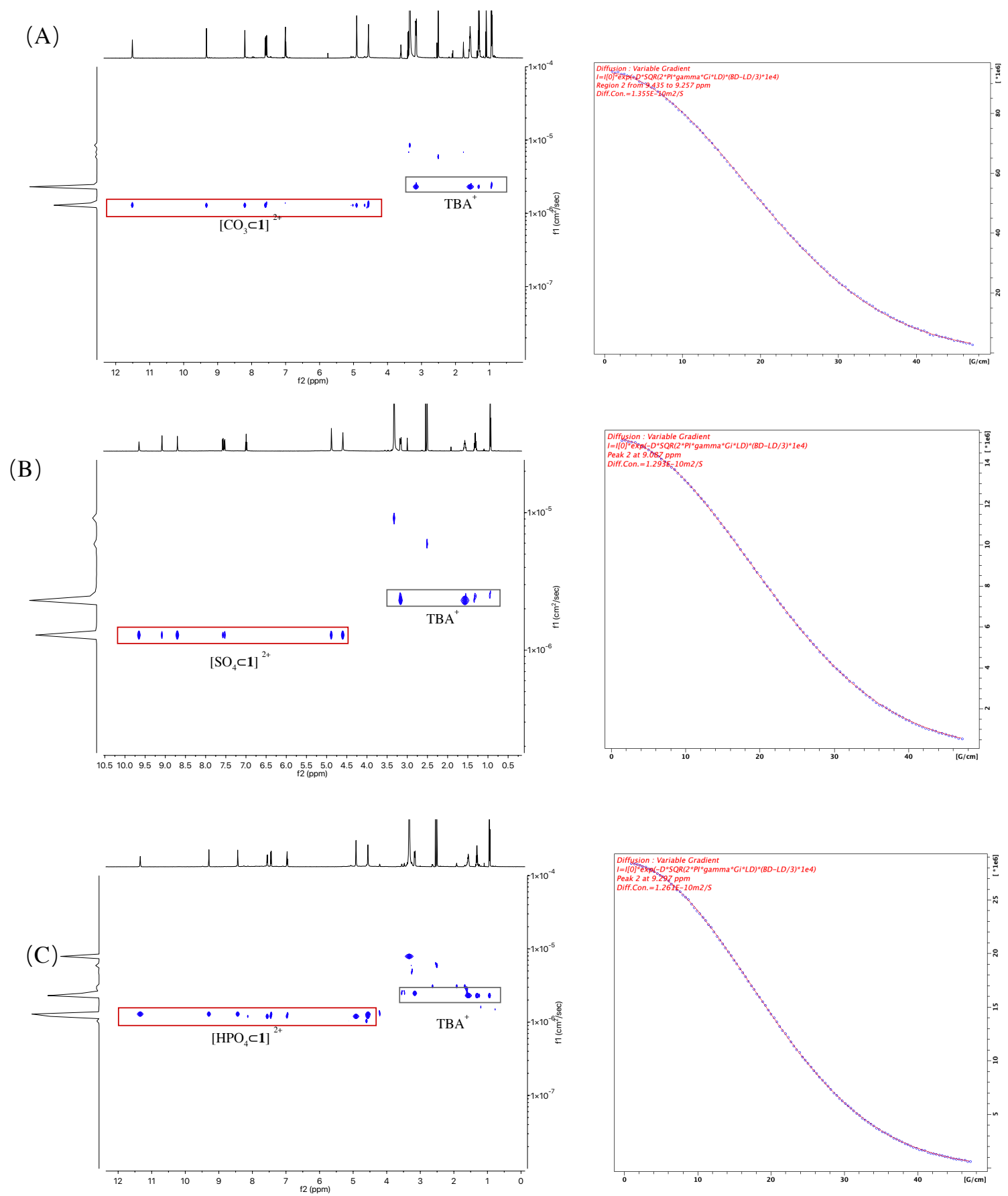

Figure S10. DOSY NMR spectra $(600 \mathrm{MHz}, 298 \mathrm{~K})$ of (A) $\left[\mathrm{CO}_{3} \subset \mathbf{1}\right] \mathrm{TBA}_{2}$, , B) $\left[\mathrm{SO}_{4} \subset 1\right] \mathrm{TBA}_{2}$ and $(\mathrm{C})\left[\mathrm{HPO}_{4} \subset \mathbf{c}\right] \mathrm{TBA}_{2}$ in DMSO-$d_{6}$. The change in intensity of resonance corresponding to $\mathbf{H}_{\mathbf{c}}$ proton as a function of the field gradient $g(\mathrm{G} / \mathrm{cm})$ was obtained using the pulse field gradient stimulated echo sequence with bipolar gradient pulse pair, 1 spoil gradient, stebpgp1s pulse sequence. The data was fit to the Stejskal-Tanner equation to give the value of diffusion coefficient $D_{\text {app }}\left(\mathrm{m}^{2} / \mathrm{s}\right)$; The hydrodynamic radii (r) was calculated using the Stokes-Einstein equation with the viscosity of DMSO being $\eta=1.987 \mathrm{mPa}$ s at $298 \mathrm{~K}$. Computed $D_{a p p}$ and hydrodynamic radii $r_{\mathrm{H}}$ are as follows: (A) $D_{\text {app }}=1.36 \times 10^{-10} \mathrm{~m}^{2} \mathrm{~s}^{-1}$ and $r_{\mathrm{H}}=8.1 \AA$ (B) $D_{\text {app }}=1.29 \times 10^{-10} \mathrm{~m}^{2} \mathrm{~s}^{-1}$ and $r_{\mathrm{H}}=8.5 \AA$, (C) $D_{a p p}=1.26 \times 10^{-10} \mathrm{~m}^{2} \mathrm{~s}^{-1}$ and $r_{\mathrm{H}}=8.7 \AA$. 


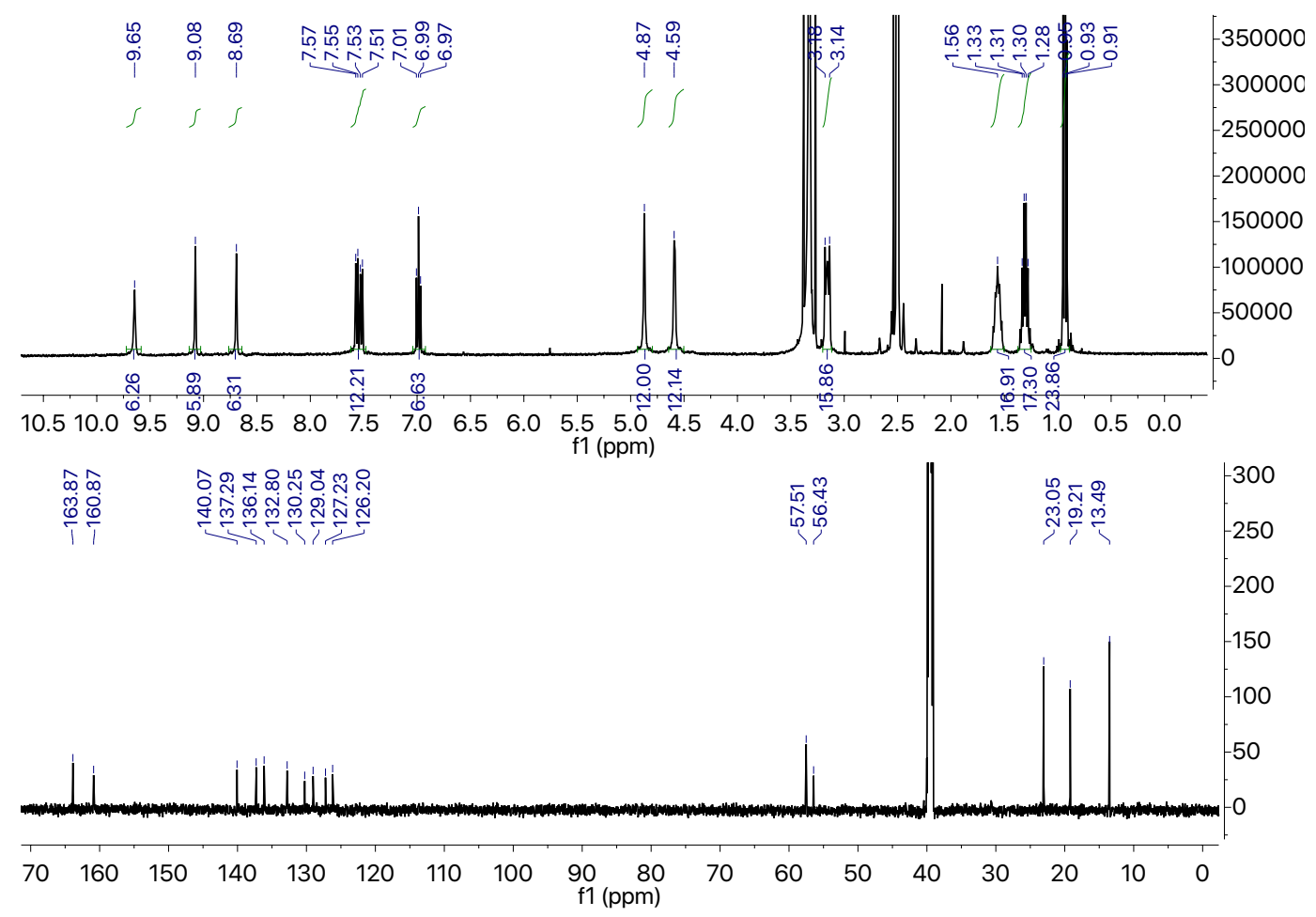

Figure S11. (Top) ${ }^{1} \mathrm{H}$ NMR spectrum $(700 \mathrm{MHz}, 298 \mathrm{~K})$ of [ $\left.\mathbf{S O}_{\mathbf{4}} \subset \mathbf{1}\right] \mathbf{T B A}_{\mathbf{2}}$ in DMSO- $d_{6}$. (Bottom) ${ }^{13} \mathrm{C}$ NMR spectrum $\left(176 \mathrm{MHz}, 298 \mathrm{~K}\right.$ ) of $\left[\mathbf{S O}_{4} \subset \mathbf{1}\right] \mathbf{T B A}_{2}$ in DMSO- $d_{6}$.

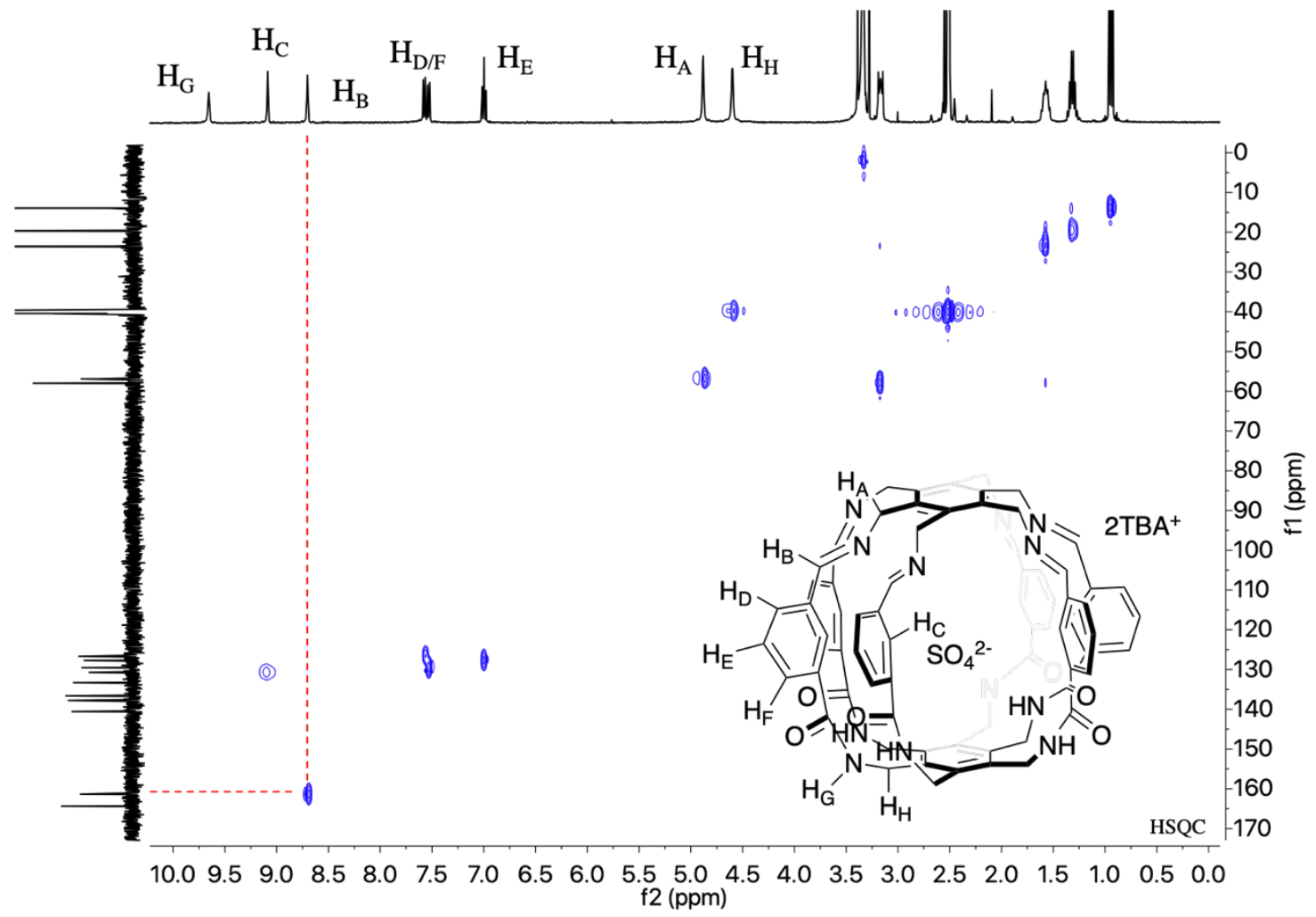

Figure S12. ${ }^{1} \mathrm{H}_{-}{ }^{13} \mathrm{C}$ HSQC NMR spectrum $(700 \mathrm{MHz}, 298 \mathrm{~K})$ of $\left[\mathbf{S O}_{4} \subset \mathbf{1}\right] \mathbf{T B A}_{2}$ in DMSO- $d_{6}$. 


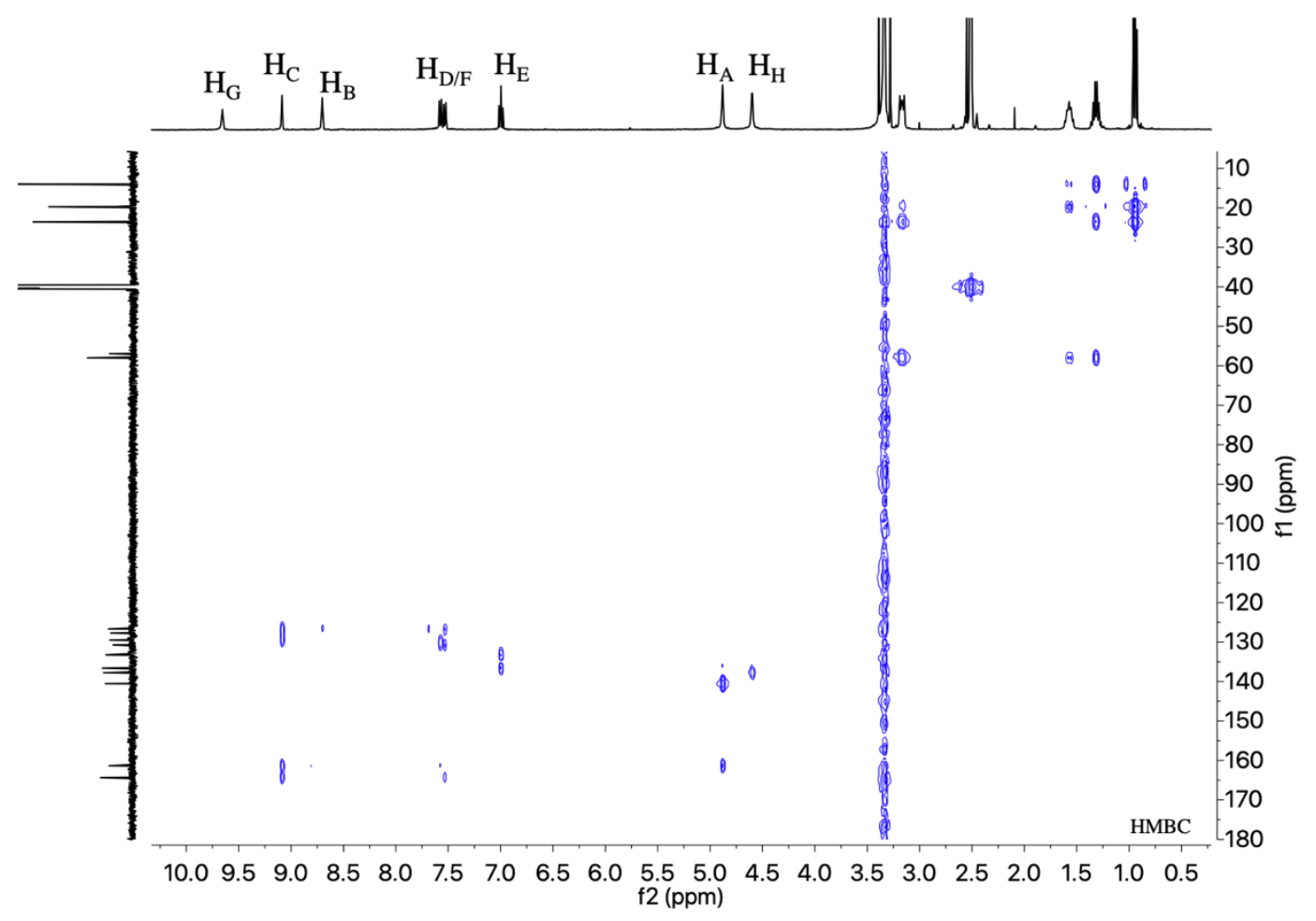

Figure S13. ${ }^{1} \mathrm{H}_{-}{ }^{13} \mathrm{C}$ HMBC NMR spectrum $(700 \mathrm{MHz}, 298 \mathrm{~K})$ of [SO $4 \subset \mathbf{1}$ ] TBA 2 in DMSO- $d_{6}$.

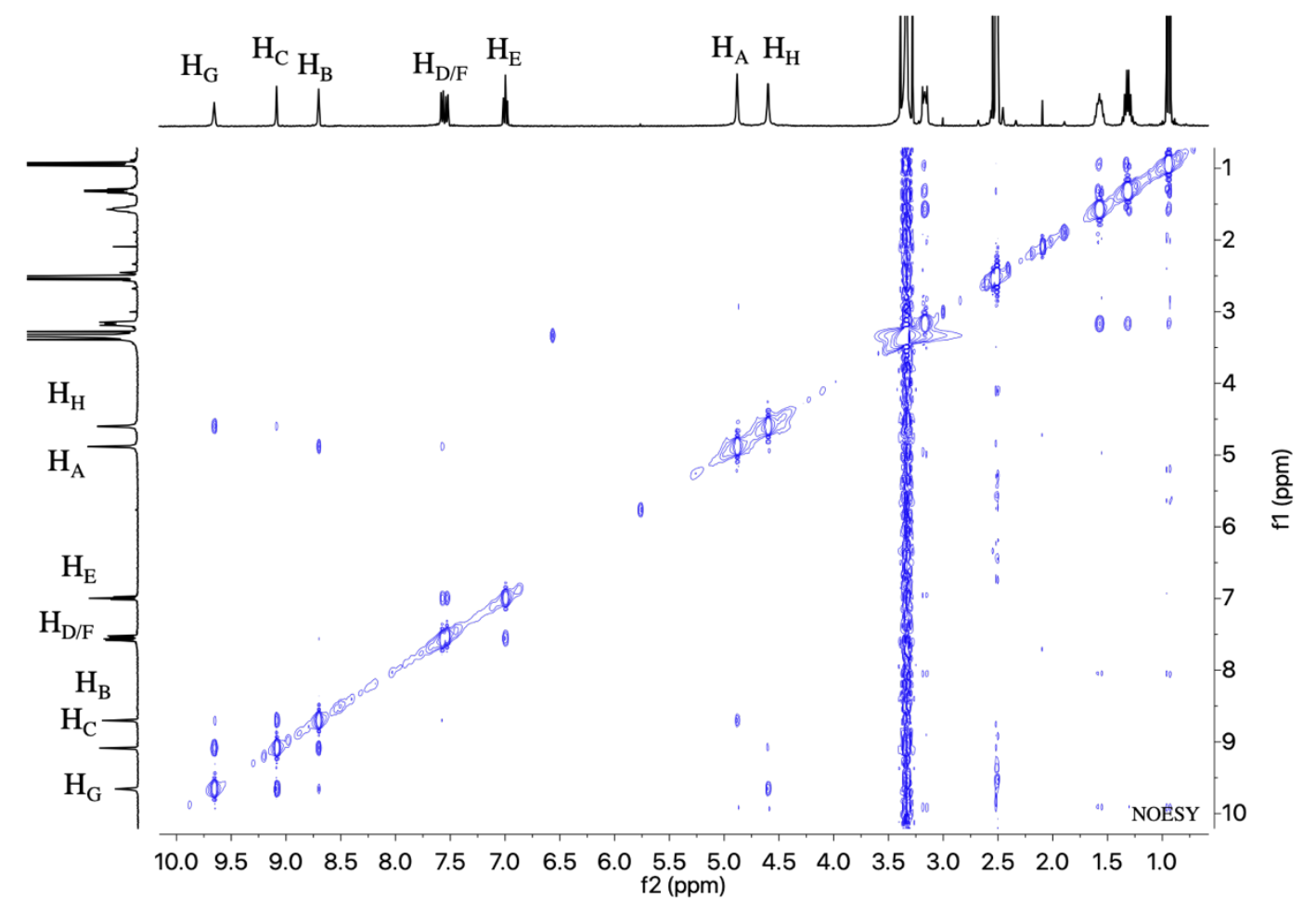

Figure S14. ${ }^{1} \mathrm{H}-{ }^{1} \mathrm{H}$ NOESY NMR spectrum $(700 \mathrm{MHz}, 298 \mathrm{~K})$ of $\left[\mathbf{S O}_{4} \subset \mathbf{1}\right] \mathbf{T B A} \mathbf{A}_{2}$ in DMSO- $d_{6}$. 


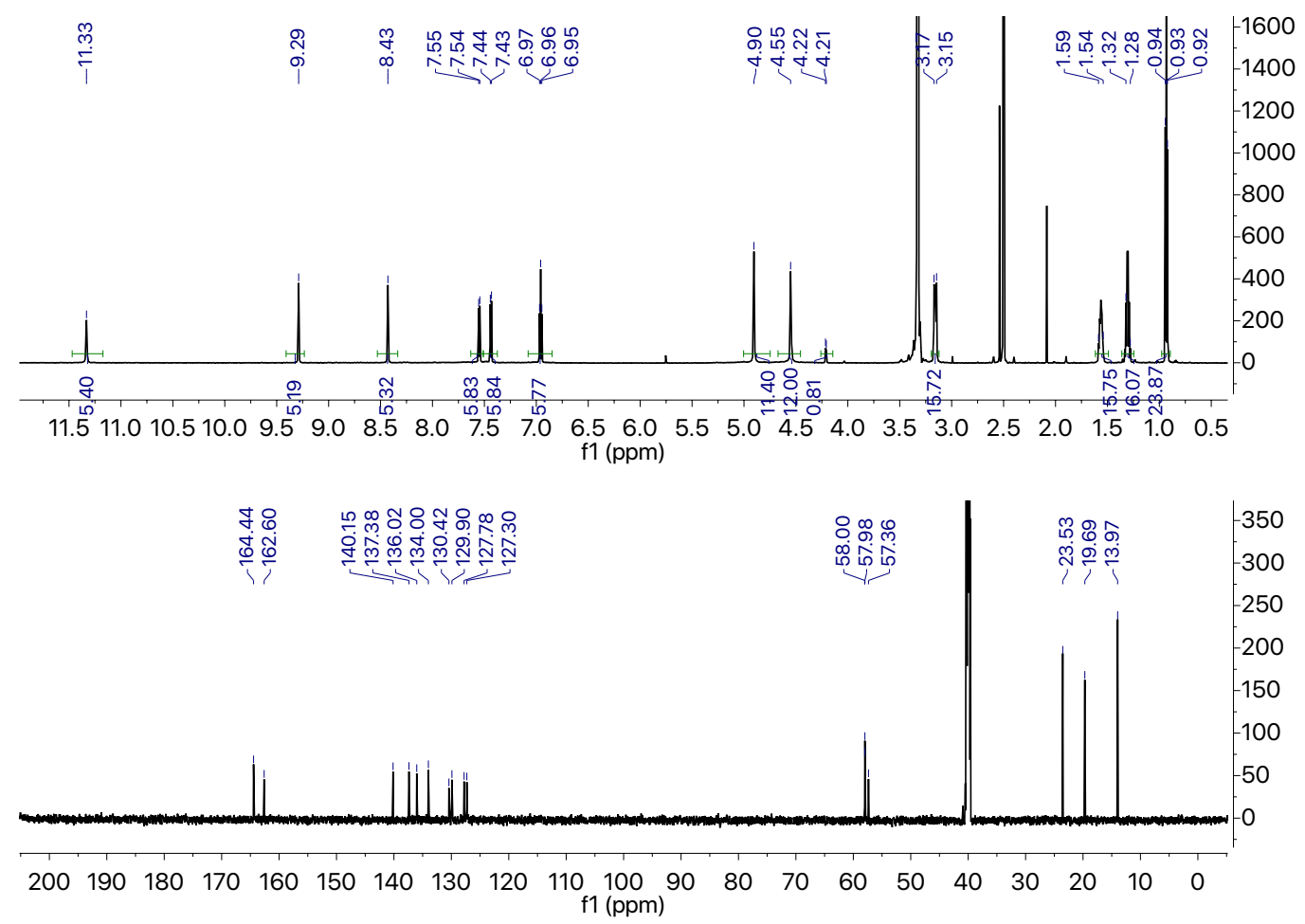

Figure S15. (Top) ${ }^{1} \mathrm{H}$ NMR spectrum $(700 \mathrm{MHz}, 298 \mathrm{~K})$ of $\left[\mathbf{H P O}_{4} \subset \mathbf{1}\right] \mathbf{T B A}_{2}$ in DMSO- $d_{6}$. (Bottom) ${ }^{13} \mathrm{C}$ NMR spectrum $(176 \mathrm{MHz}, 298 \mathrm{~K})$ of [HPO4$\subset \mathbf{1}$ ] TBA 2 in DMSO- $d_{6}$.

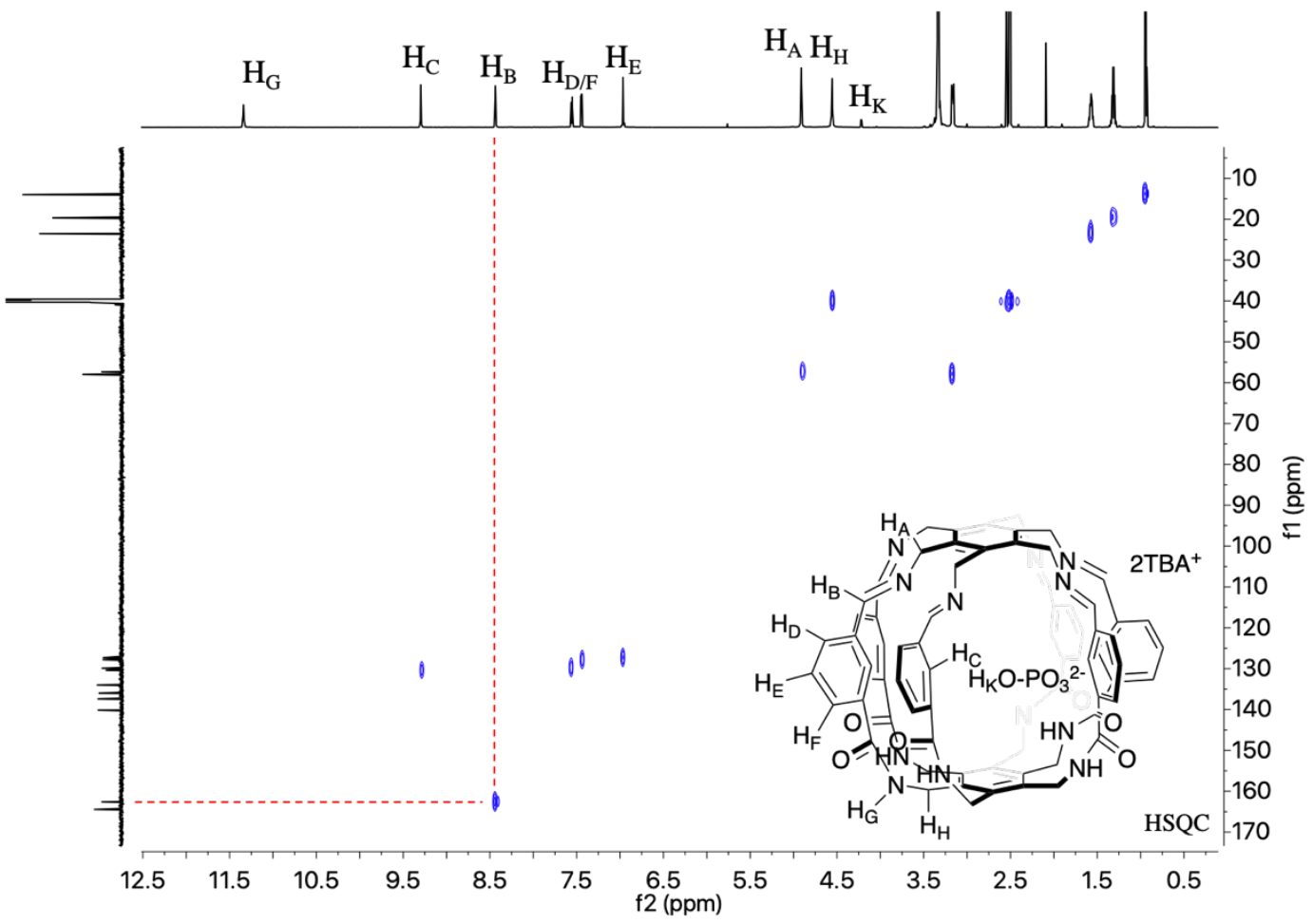

Figure S16. ${ }^{1} \mathrm{H}^{13} \mathrm{C}$ HSQC NMR spectrum $(700 \mathrm{MHz}, 298 \mathrm{~K})$ of $\left[\mathbf{H P O}_{\mathbf{4}} \subset \mathbf{1}\right] \mathbf{T B} \mathbf{A}_{2}$ in DMSO- $d_{6}$. 


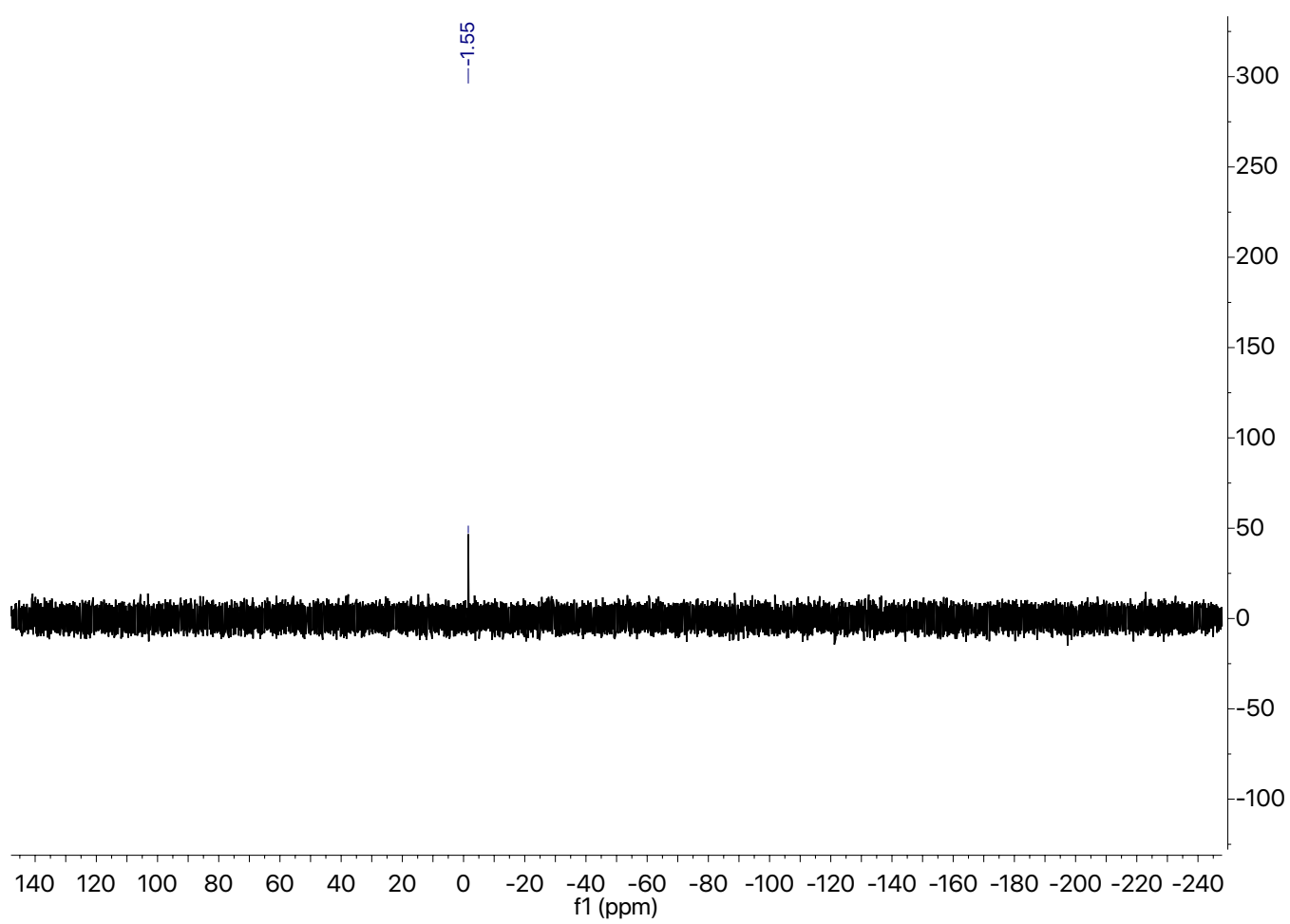

Figure S17. ${ }^{31} \mathrm{P}$ NMR spectrum $(243 \mathrm{MHz}, 298 \mathrm{~K})$ of $\left[\mathbf{H P O}_{4} \subset \mathbf{1}\right] \mathbf{T B A}_{2}$ in DMSO-d6.

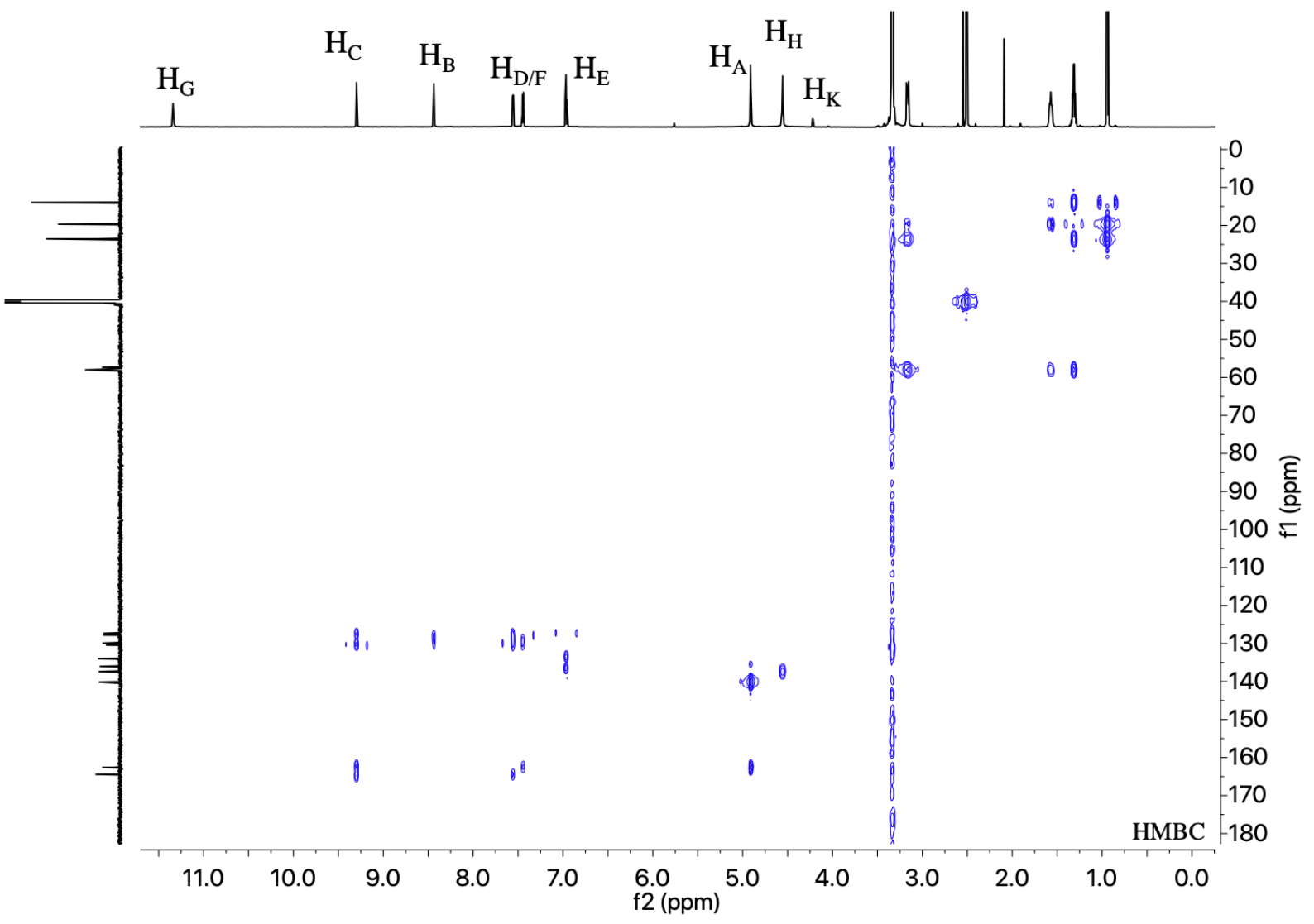

Figure S18. ${ }^{1} \mathrm{H}_{-}{ }^{13} \mathrm{C}$ HMBC NMR spectrum $(700 \mathrm{MHz}, 298 \mathrm{~K})$ of [HPO $\left.\mathbf{H}_{\mathbf{4}} \subset \mathbf{1}\right] \mathbf{T B A}_{2}$ in DMSO- $d_{6}$. 


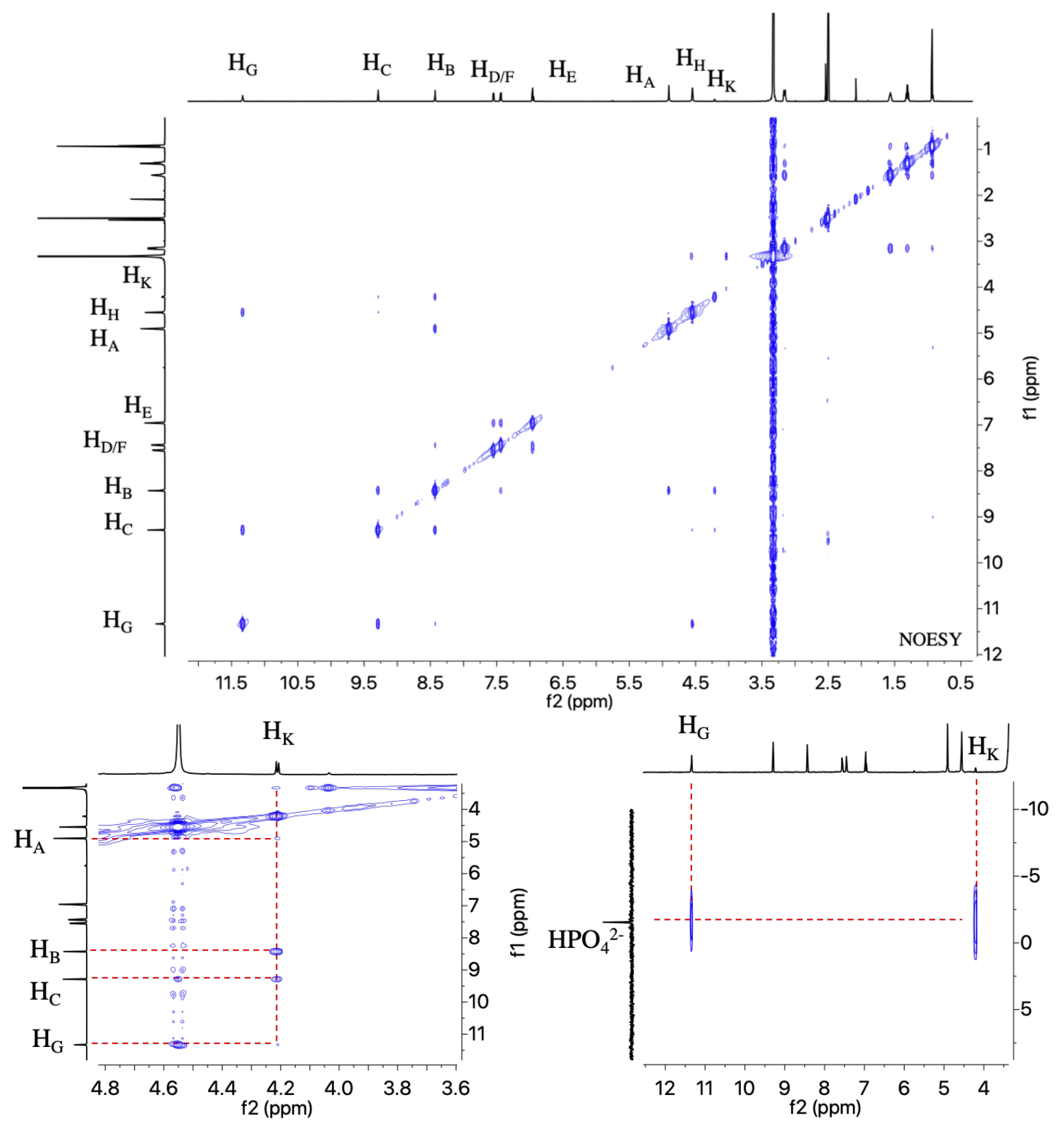

Figure S19. (Top) ${ }^{1} \mathrm{H}^{-1} \mathrm{H}$ NOESY NMR spectrum $(600 \mathrm{MHz}, 298 \mathrm{~K})$ of $\left[\mathbf{H P O}_{4} \subset \mathbf{1}\right] \mathbf{T B A}_{2}$ in DMSO- $d_{6}$. (Bottom left) A segment from ${ }^{1} \mathrm{H}-{ }^{1} \mathrm{H}$ NOESY NMR spectrum shows two correlations indicating a short distance between $\mathrm{H}_{\mathrm{K}}$ and $\mathrm{H}_{\mathrm{B} / \mathrm{C}}$ protons $\left(<5-6 \AA\right.$ ). (Bottom right) ${ }^{1} \mathrm{H}_{-}{ }^{31} \mathrm{P} \mathrm{HMBC}$ NMR spectrum $(600 \mathrm{MHz}, 298 \mathrm{~K})$ of $\left[\mathbf{H P O}_{4} \subset \mathbf{1}\right] \mathbf{T B A} \mathbf{A}_{2}$ in DMSO- $d_{6}$. The cross signal between phosphorus and $\mathbf{H}_{\mathrm{G}}$ from capsule $\mathbf{1}$ suggests an intermolecular hydrogen bonding. 


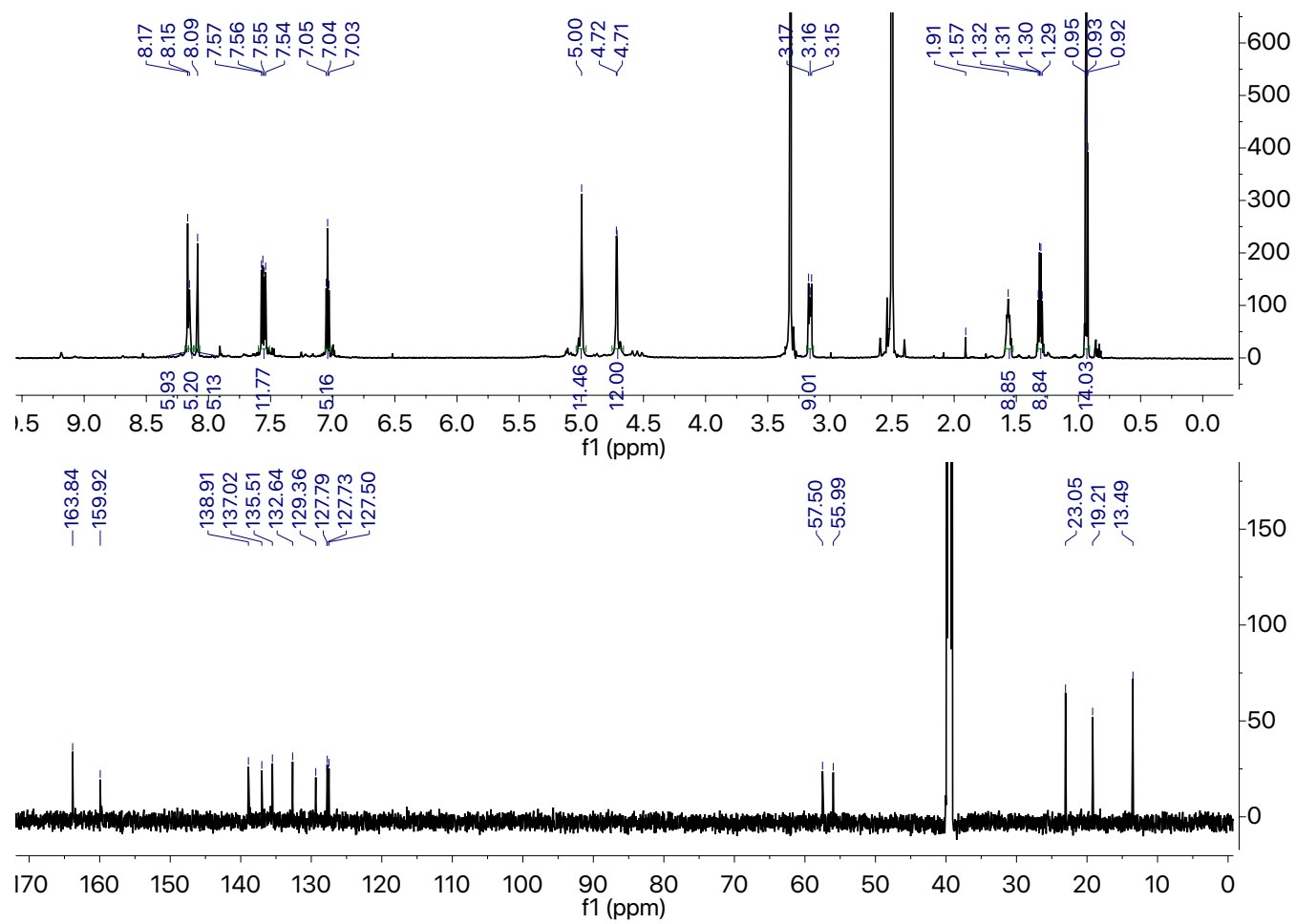

Figure S20. (Top) ${ }^{1} \mathrm{H}$ NMR spectrum $(700 \mathrm{MHz}, 298 \mathrm{~K})$ of $[\mathbf{C l} \subset \mathbf{1}]$ TBA in DMSO- $d_{6}$. (Bottom)

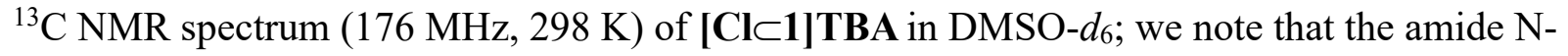
$\mathrm{H}_{\mathrm{G}}$ signal could be shifting due to variable concentration of water.

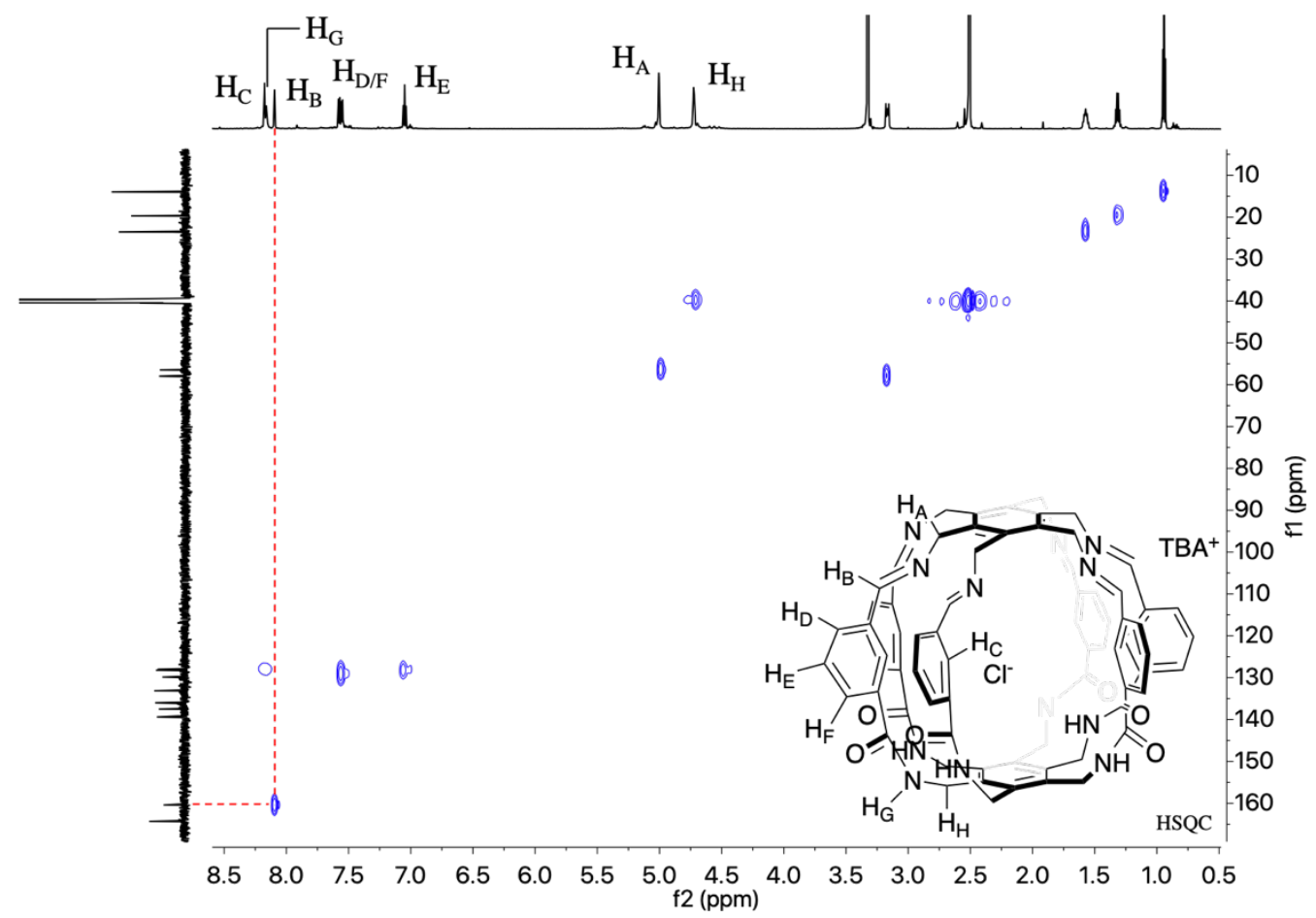

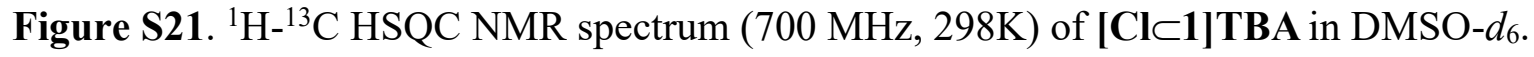




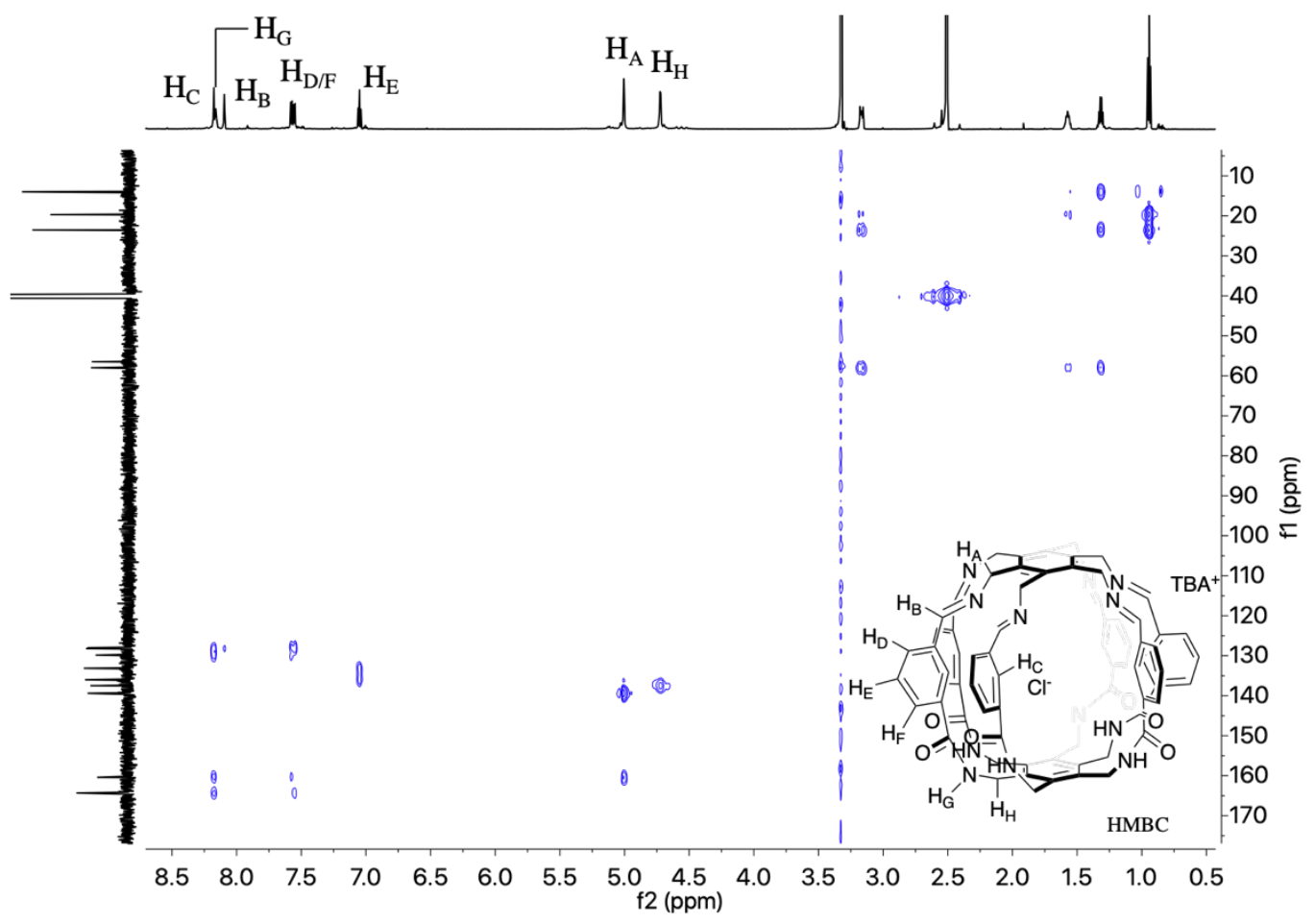

Figure S22. ${ }^{1} \mathrm{H}_{-}{ }^{13} \mathrm{C}$ HMBC NMR spectrum $(700 \mathrm{MHz}, 298 \mathrm{~K})$ of [Cl $\left.\subset \mathbf{1}\right]$ TBA in DMSO- $d_{6}$.

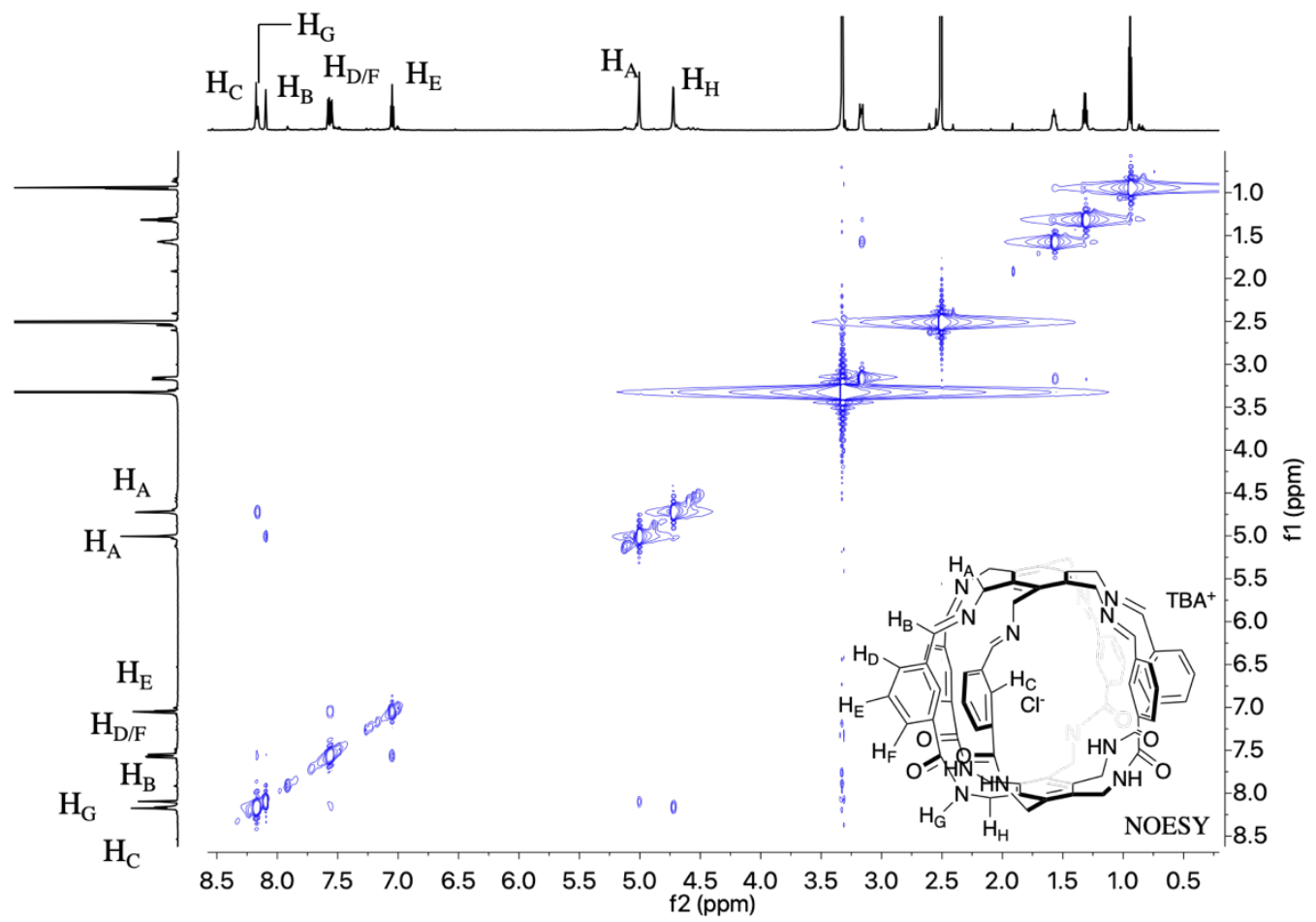

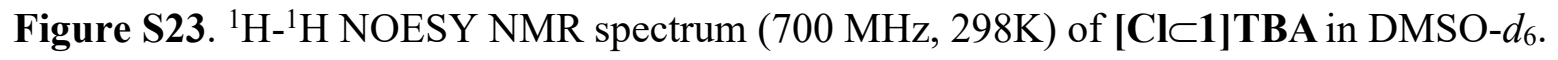




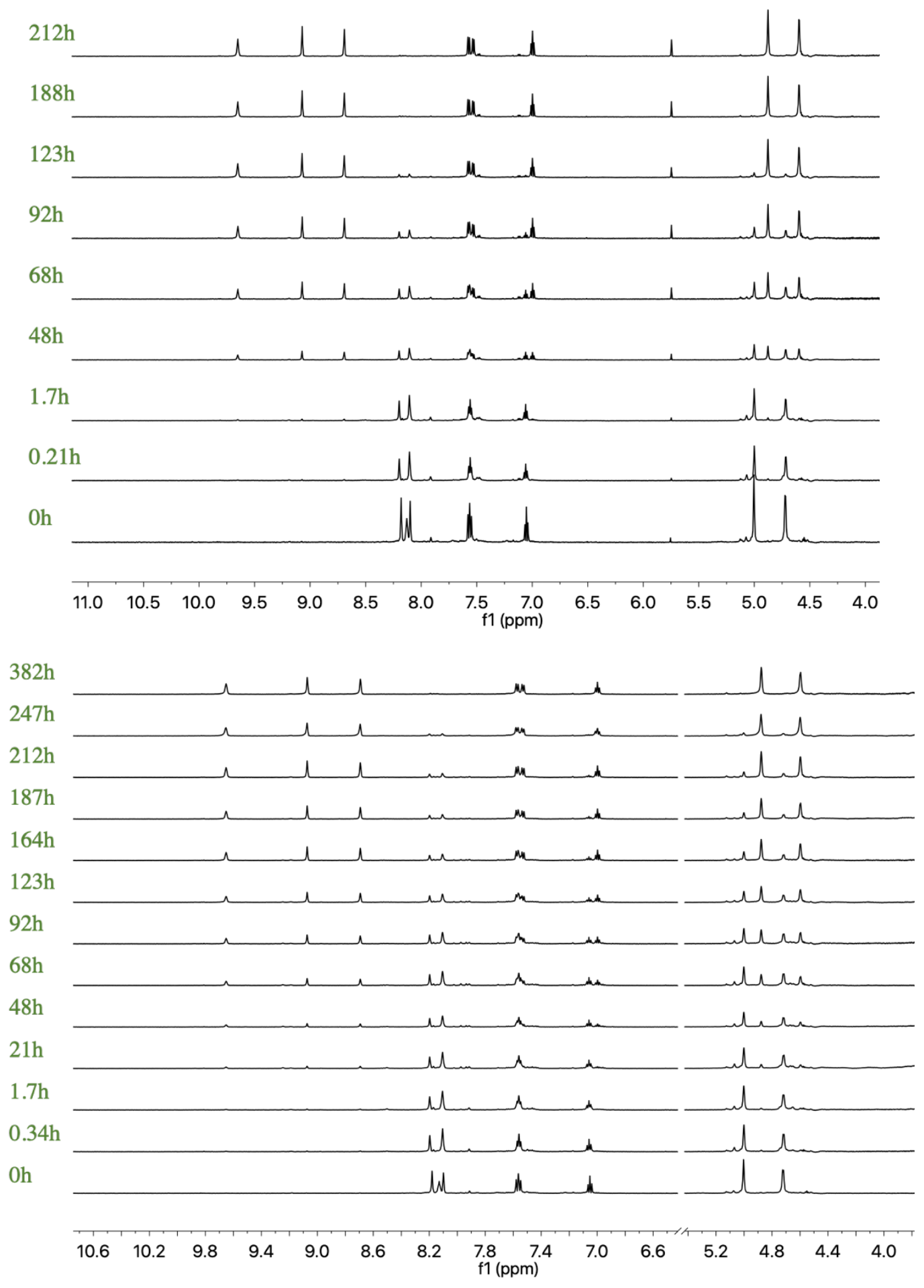

Figure S24. To a solution of [Cl $\subset \mathbf{1}]$ TBA $\left(2.8 \times 10^{-4} \mathrm{mmol}\right)$ in $425 \mu \mathrm{L}$ of DMSO- $d_{6}$ with (top) and without (bottom) $p$-TsOH $\left(5.6 \times 10^{-5} \mathrm{mmol}\right)$, we added $\mathrm{Na}_{2} \mathrm{SO}_{4}\left(4.2 \times 10^{-4} \mathrm{mmol}\right)$ and monitored the process with ${ }^{1} \mathrm{H}$ NMR spectroscopy $(600 \mathrm{MHz}, 298 \mathrm{~K})$. 


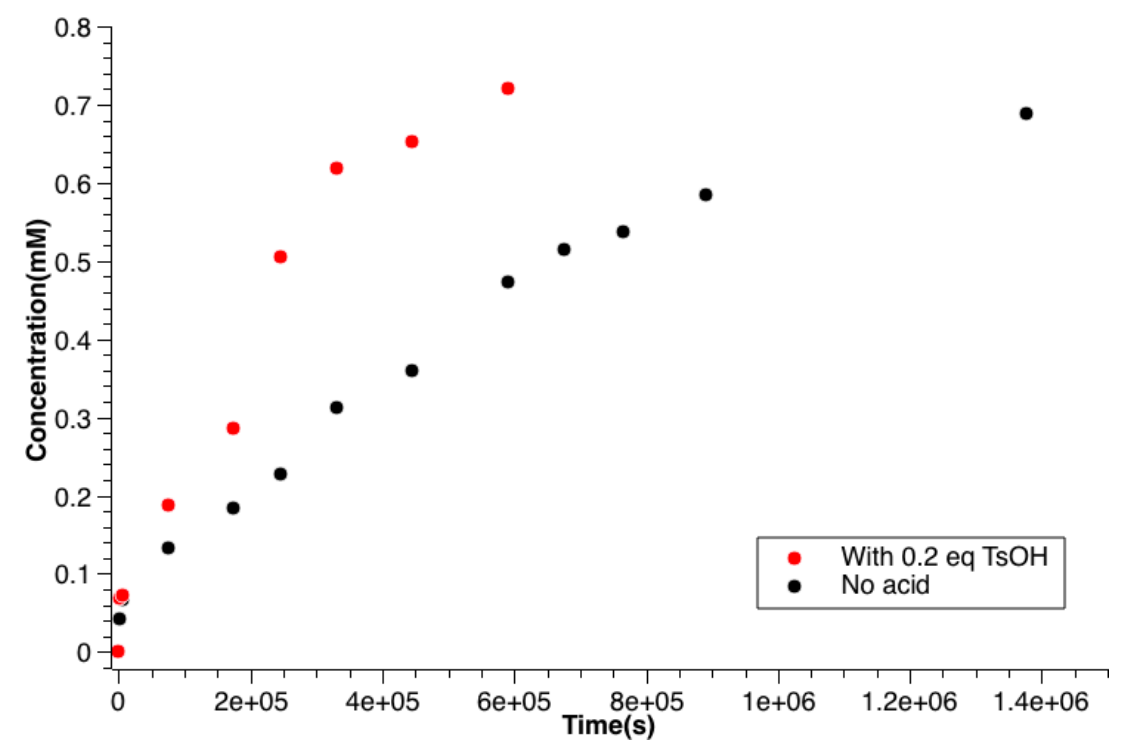

Figure S25. A plot showing the increase in concentration of $\left[\mathrm{SO}_{4} \subset \mathbf{1}\right] \mathbf{T B A}_{2}$ as a function of time with (red) and without (black) $p-\mathrm{TsOH}$ at $298 \mathrm{~K}$. The data was obtained by integration of ${ }^{1} \mathrm{H} \mathrm{NMR}$ signals in Figure $\mathbf{S 2 4}$. 


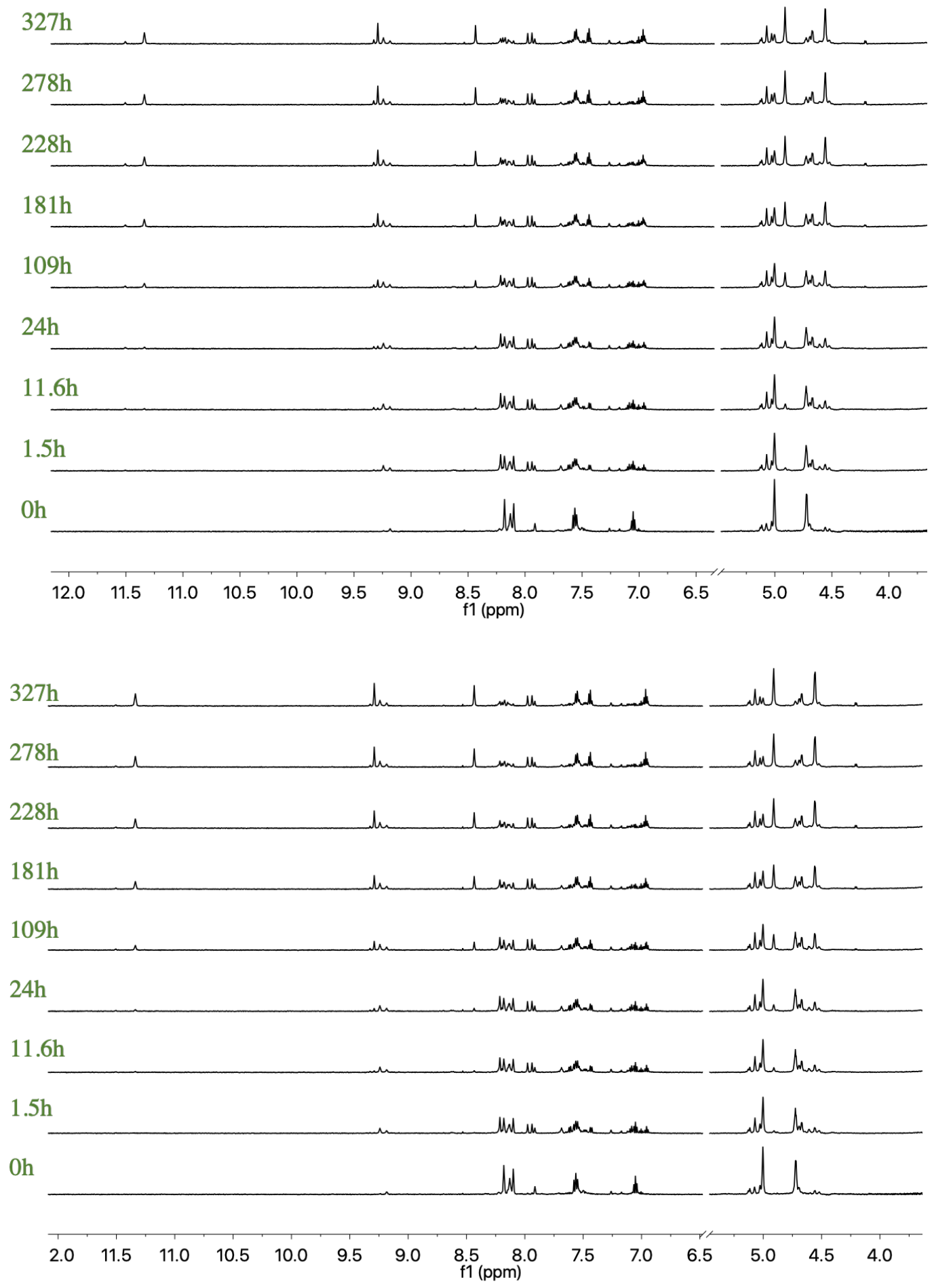

Figure S26. To a solution of [Cl $\subset$ 1] TBA $\left(2.1 \times 10^{-4} \mathrm{mmol}\right)$ in $425 \mu \mathrm{L}$ of DMSO- $d_{6}$ with (top) and without (bottom) $p$-TsOH $\left(4.1 \times 10^{-5} \mathrm{mmol}\right)$, we added TBA(DBU-H)HPO $4\left(3.1 \times 10^{-4} \mathrm{mmol}\right)$ and monitored the process with ${ }^{1} \mathrm{H}$ NMR spectroscopy $(600 \mathrm{MHz}, 298 \mathrm{~K})$. 


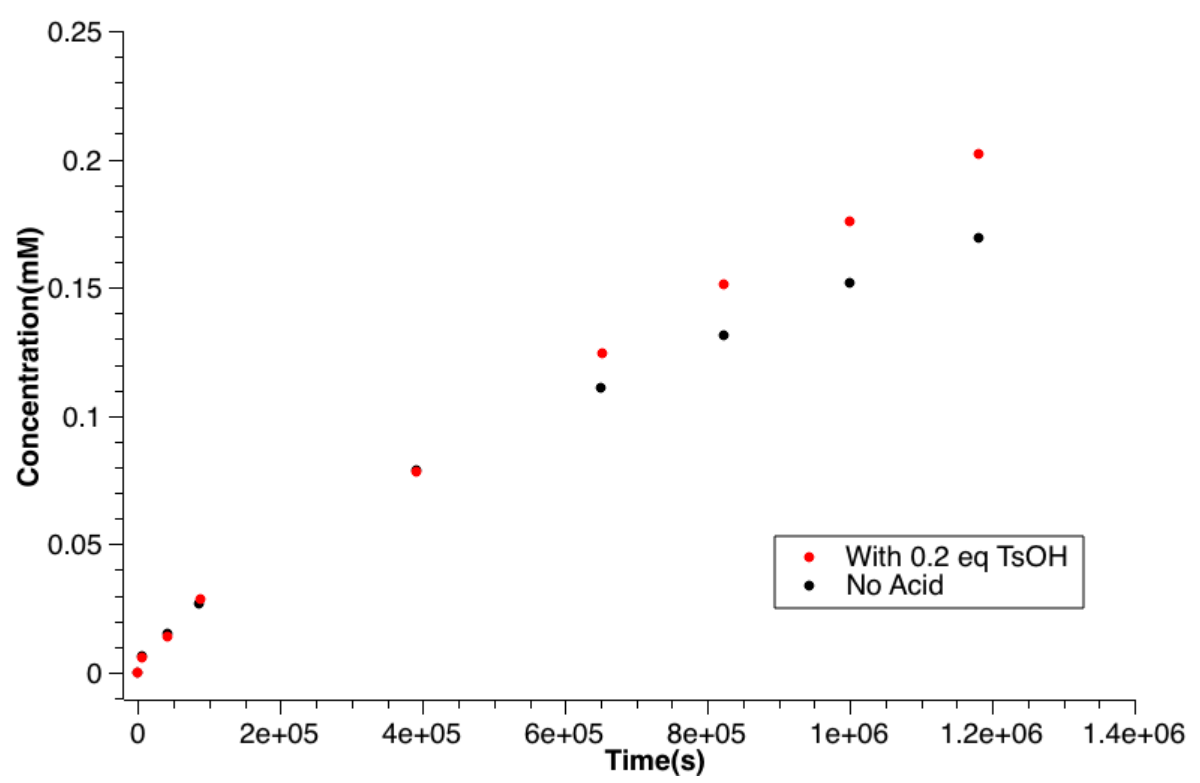

Figure S27. A plot showing the increase in concentration of [HPO4$\subset \mathbf{H}] \mathbf{T B A}_{2}$ as a function of time with (red) and without (black) $p$-TsOH at $298 \mathrm{~K}$. The data was obtained by integration of ${ }^{1} \mathrm{H} \mathrm{NMR}$ signals in Figure S26. 
(A)

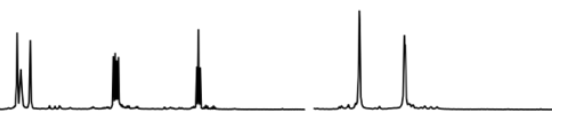

(B)

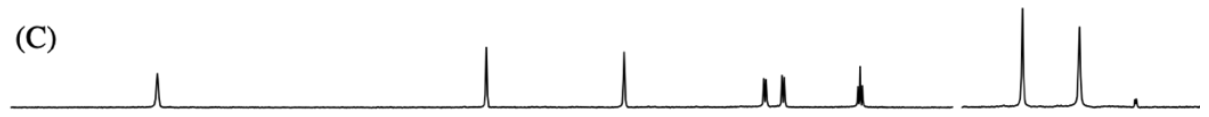

(D)

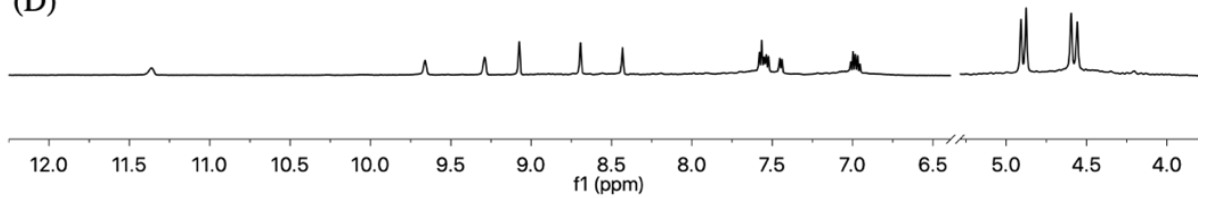

Figure S28. Partial ${ }^{1} \mathrm{H}$ NMR spectra (600 MHz, 298K) of (A) [Cl $\subset$ 1] TBA (B) [SO4 $\subset$ 1]TBA 2 and (C) $\left[\mathbf{H P O}_{4} \subset \mathbf{1}\right] \mathbf{T B A}_{2}$ in DMSO- $d_{6}$. (D) Partial ${ }^{1} \mathrm{H}$ NMR spectra $(600 \mathrm{MHz}, 298 \mathrm{~K})$ obtained from the reaction of $2(0.0019 \mathrm{mmol})$ and $3(0.0019 \mathrm{mmol})$ in $500 \mu \mathrm{L}$ DMSO solution $(90 \%$ DMSO $10 \%$ DMSO- $d_{6}$, see Figure $\mathrm{S} 1$ for additional experimental details) containing $\mathrm{TBA}_{2} \mathrm{SO}_{4}(0.0019$ $\mathrm{mmol}), \mathrm{TBA}_{2} \mathrm{HPO}_{4}(0.0019 \mathrm{mmol})$ and $\mathrm{TBACl}(0.0019 \mathrm{mmol})$. From the integration of ${ }^{1} \mathrm{H} \mathrm{NMR}$ signals, $55 \%$ of $\left[\mathbf{S O}_{4} \subset \mathbf{1}\right]^{2-}$ and $45 \%$ of $\left[\mathrm{HPO}_{4} \subset \mathbf{1}\right]^{2-}$ formed in the templation.

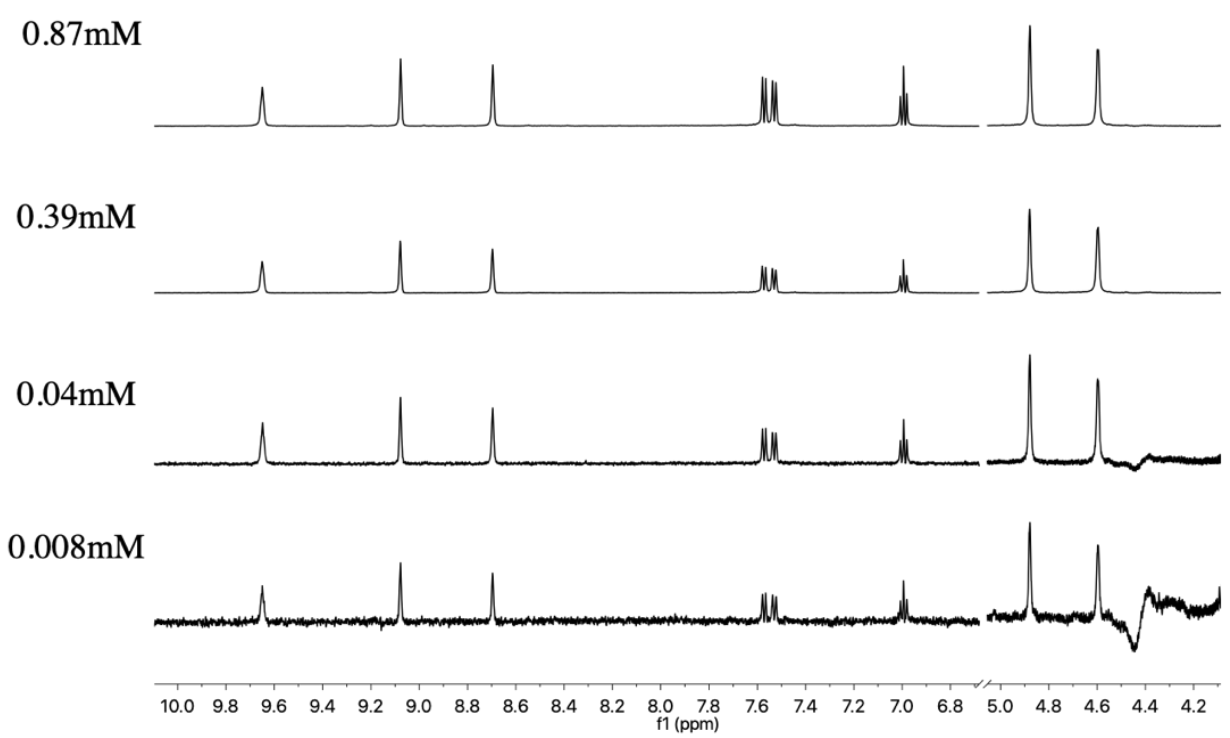

Figure S29. ${ }^{1} \mathrm{H}$ NMR spectra $(600 \mathrm{MHz}, 298 \mathrm{~K})$ of $0.008-0.87 \mathrm{mM}$ solution of [SO $\left.\mathbf{S}_{4} \subset \mathbf{1}\right] \mathbf{T B A}_{2}$ in DMSO- $d_{6}$. Each sample contained 1,3,5-trimethoxybenzene as an internal standard. With no

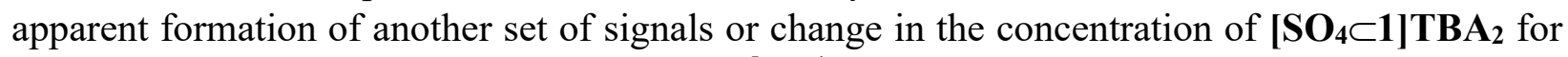
the duration of 7 days, we estimate that $K_{\mathrm{a}}>10^{5} \mathrm{M}^{-1}$ (see also Figure S30). 
(A)

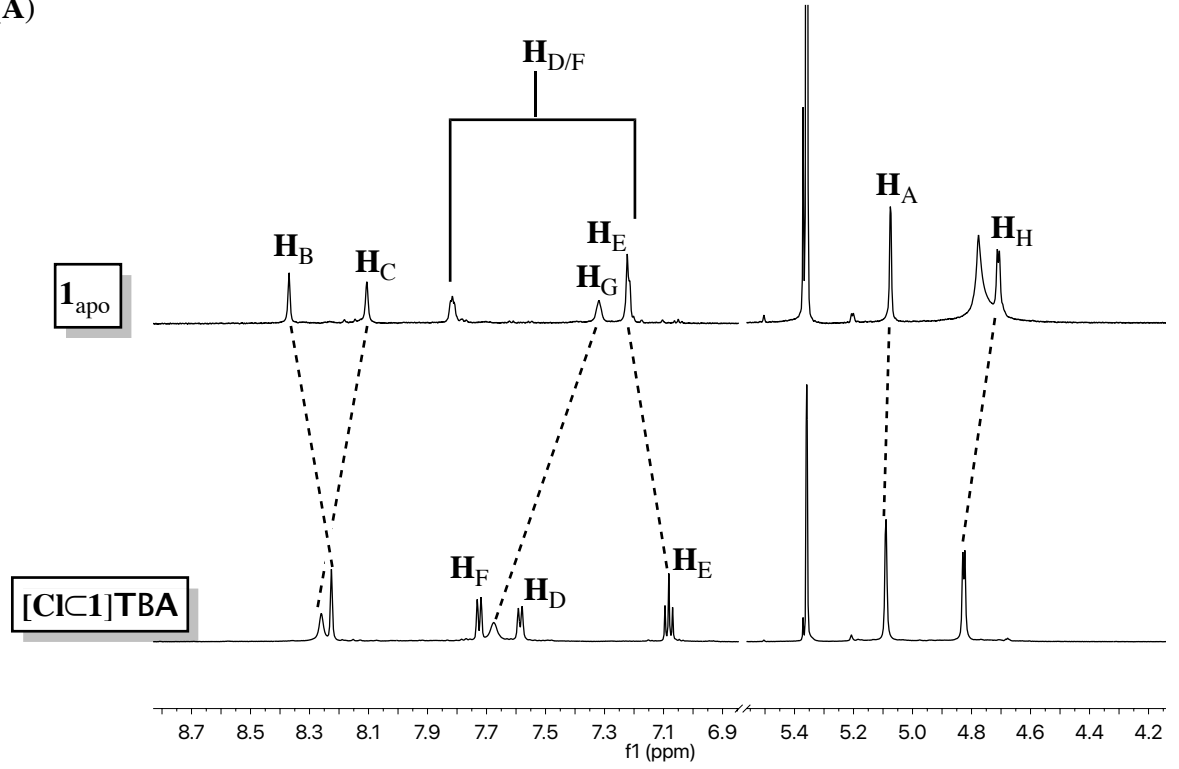

(B)

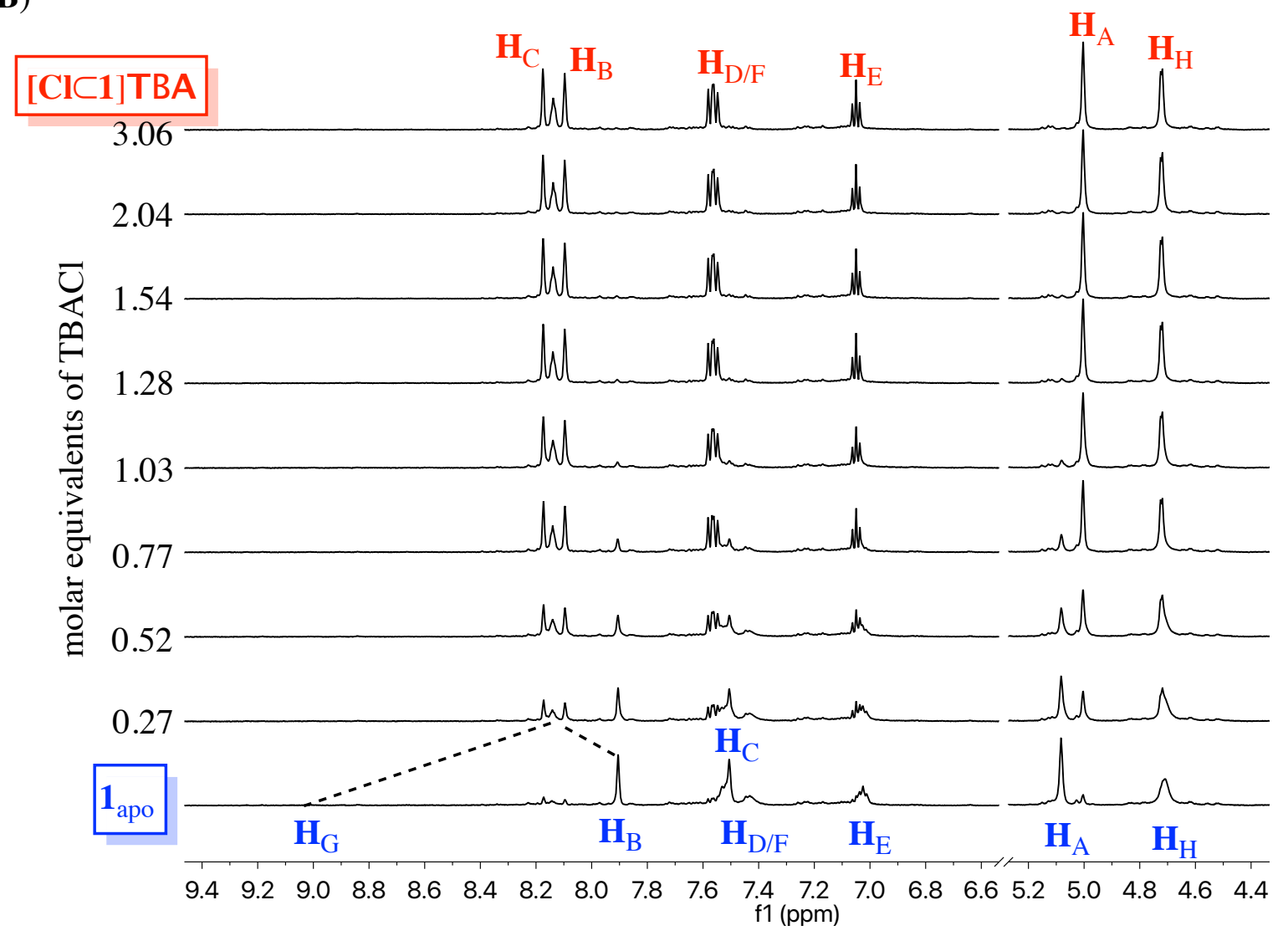

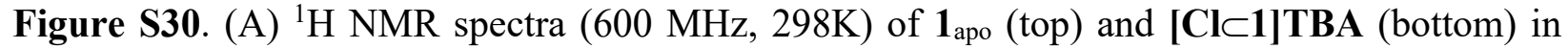
$\mathrm{CD}_{2} \mathrm{Cl}_{2}$. (B) An incremental addition of a standard solution of TBACl in DMSO- $d_{6}(20 \mathrm{mM})$ to $0.35 \mathrm{mM}$ of $\mathbf{1}_{\text {apo }}$ in DMSO- $d_{6}$ was monitored with ${ }^{1} \mathrm{H}$ NMR spectroscopy $(600 \mathrm{MHz}, 298 \mathrm{~K})$. The integration of separate ${ }^{1} \mathrm{H}$ NMR signals (red and blue) allowed us to determine concentrations of [1], $[\mathbf{C l} \subset \mathbf{1}]$ and $\mathbf{C l}^{-}$. From $K_{\mathrm{a}}=[\mathbf{C l} \subset \mathbf{1}] /\left([\mathbf{1}][\mathbf{C l}]^{-}\right)$, we determined the stability of $[\mathbf{C l} \subset \mathbf{1}]^{-}$to be $K_{\mathrm{a}}$ $=2 \cdot 10^{5} \mathrm{M}^{-1}$. With roughly one molar equivalent of sulfate fully substituting the chloride anion in $[\mathbf{C l} \subset \mathbf{1}]^{-}$(Figure S24), the stability of $\left[\mathbf{S O}_{4} \subset \mathbf{1}\right]^{2-}$ ought to be at least two orders of magnitude greater and therefore $K_{\mathrm{a}}>10^{7} \mathrm{M}^{-1}$. 


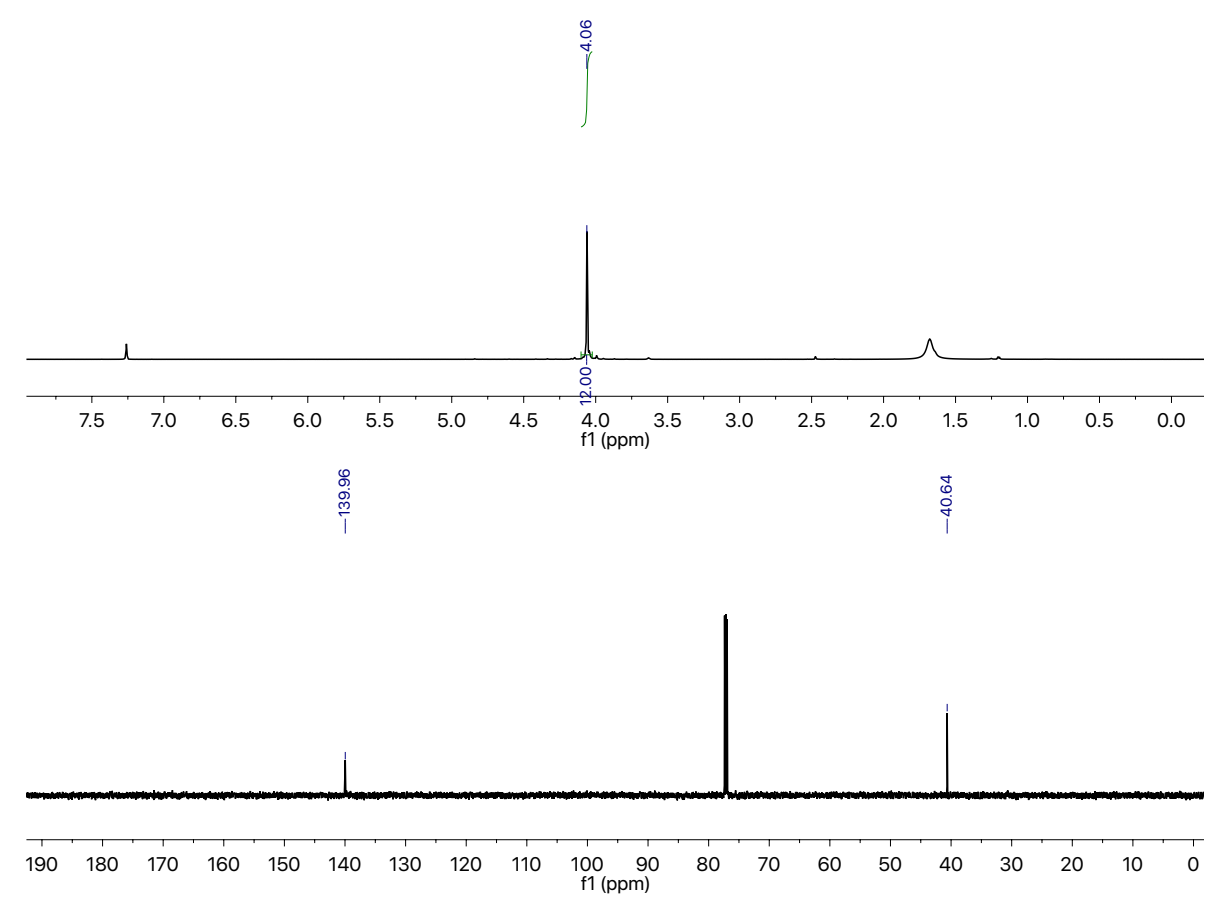

Figure S31. (Top) ${ }^{1} \mathrm{H}$ NMR spectrum (400 $\mathrm{MHz}, \mathrm{CDCl}_{3}$ ) of compound 3. (Bottom) ${ }^{13} \mathrm{C} \mathrm{NMR}$ spectrum $\left(101 \mathrm{MHz}, \mathrm{CDCl}_{3}\right)$ of compound $\mathbf{3}$.

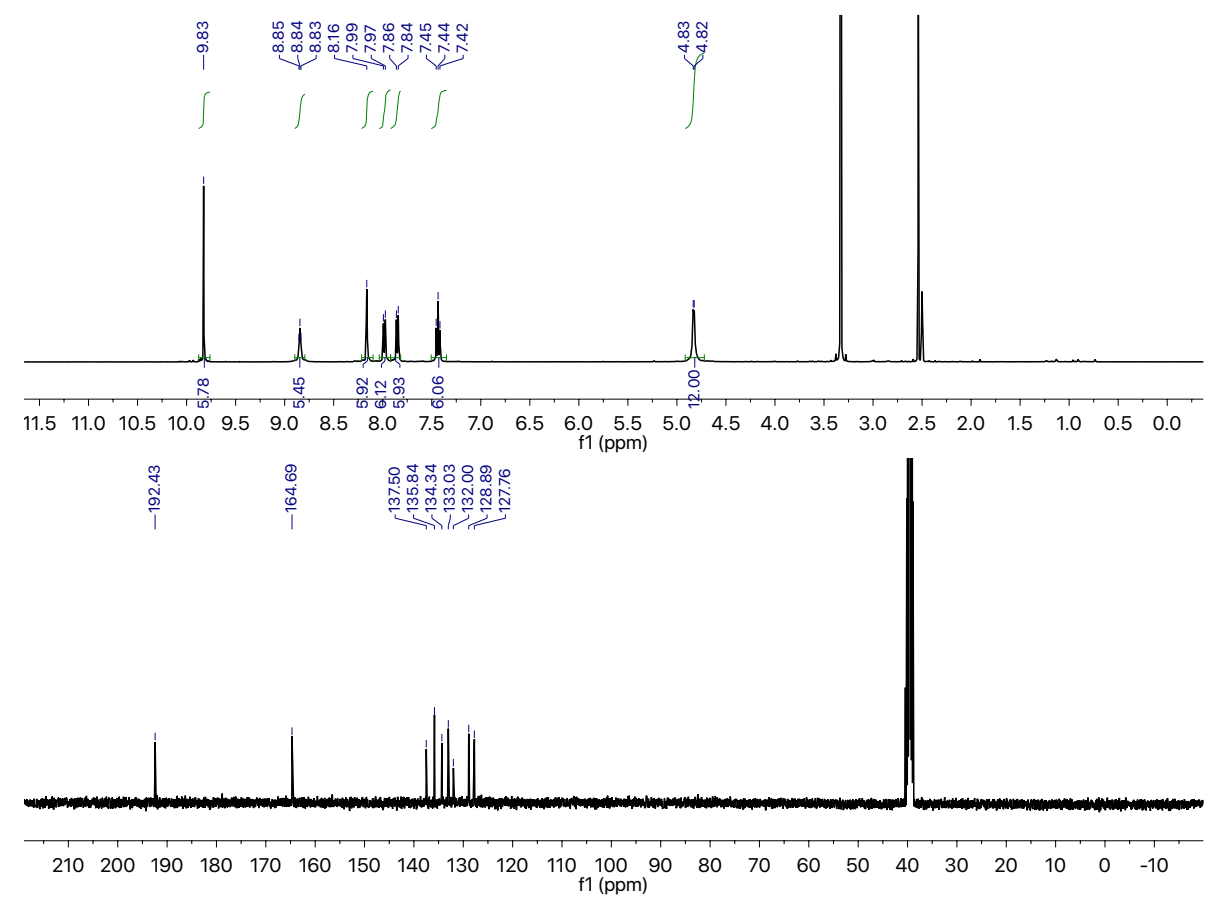

Figure S32. (Top) ${ }^{1} \mathrm{H}$ NMR spectrum (700 MHz, DMSO- $d_{6}$ ) of compound 2. (Bottom) ${ }^{13} \mathrm{C} \mathrm{NMR}$ spectrum $\left(176 \mathrm{MHz}, \mathrm{DMSO}-d_{6}\right)$ of compound 2. 


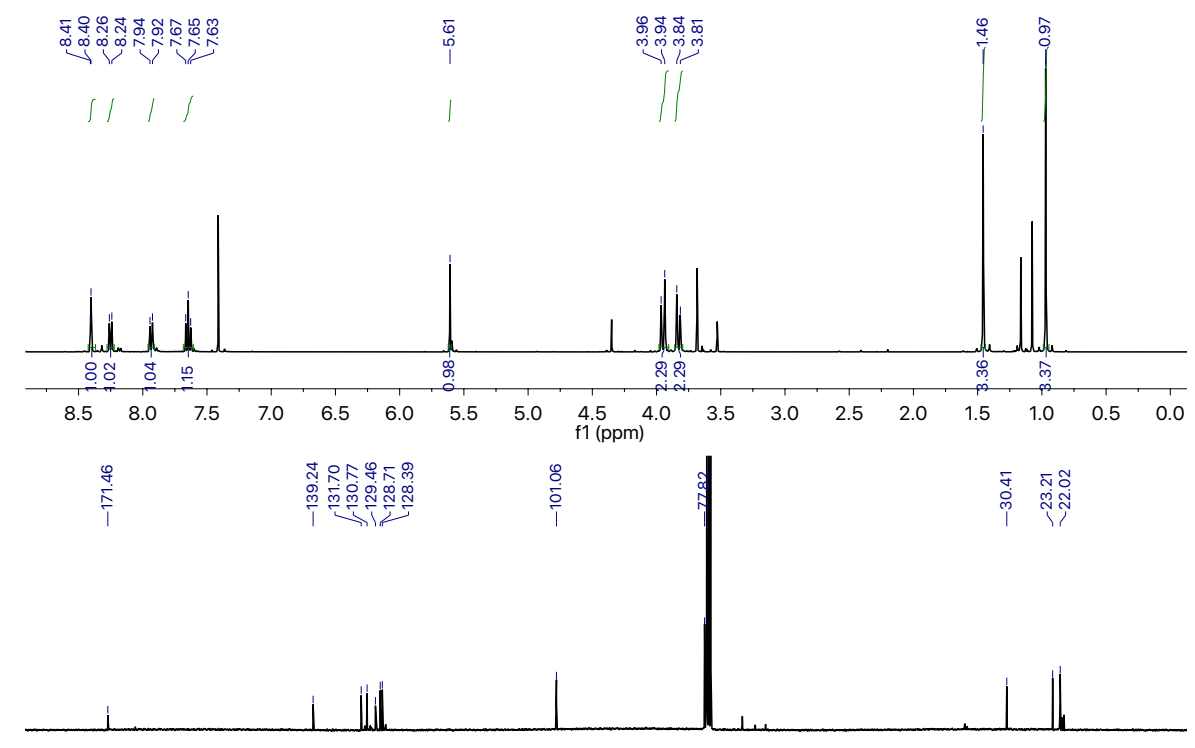

$\begin{array}{llllllllllllllllll}180 & 170 & 160 & 150 & 140 & 130 & 120 & 110 & 100_{\mathrm{f} 1(\mathrm{ppm})}^{90} & 80 & 70 & 60 & 50 & 40 & 30 & 20 & 10\end{array}$

Figure S33. (Top) ${ }^{1} \mathrm{H}$ NMR spectrum $\left(400 \mathrm{MHz}, \mathrm{CDCl}_{3}\right)$ of compound S2. (Bottom) ${ }^{13} \mathrm{C} \mathrm{NMR}$ spectrum $\left(101 \mathrm{MHz}, \mathrm{CDCl}_{3}\right)$ of compound $\mathbf{S 2}$.

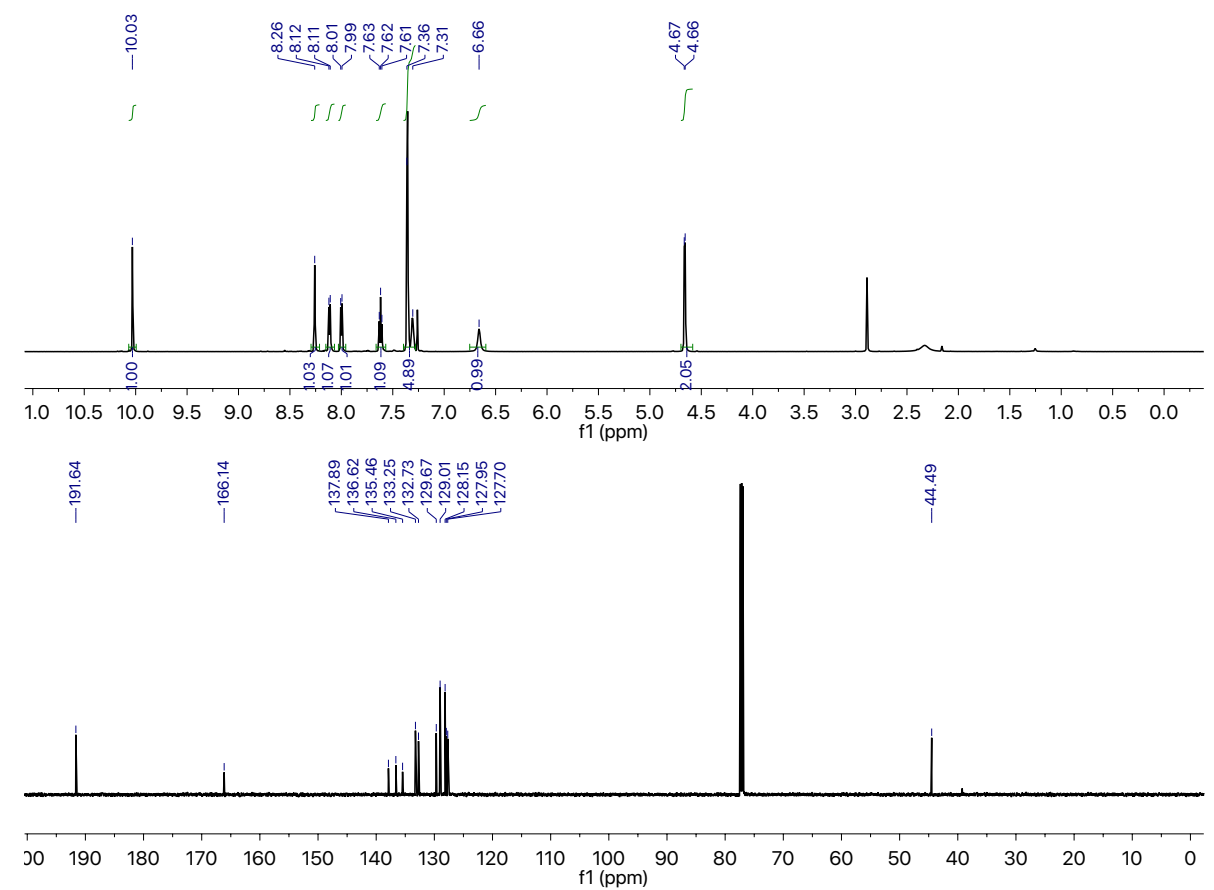

Figure S34. (Top) ${ }^{1} \mathrm{H}$ NMR spectrum $\left(400 \mathrm{MHz}, \mathrm{CDCl}_{3}\right.$ ) of compound S3. (Bottom) ${ }^{13} \mathrm{C} \mathrm{NMR}$ spectrum $\left(101 \mathrm{MHz}, \mathrm{CDCl}_{3}\right)$ of compound $\mathbf{S 3}$. 

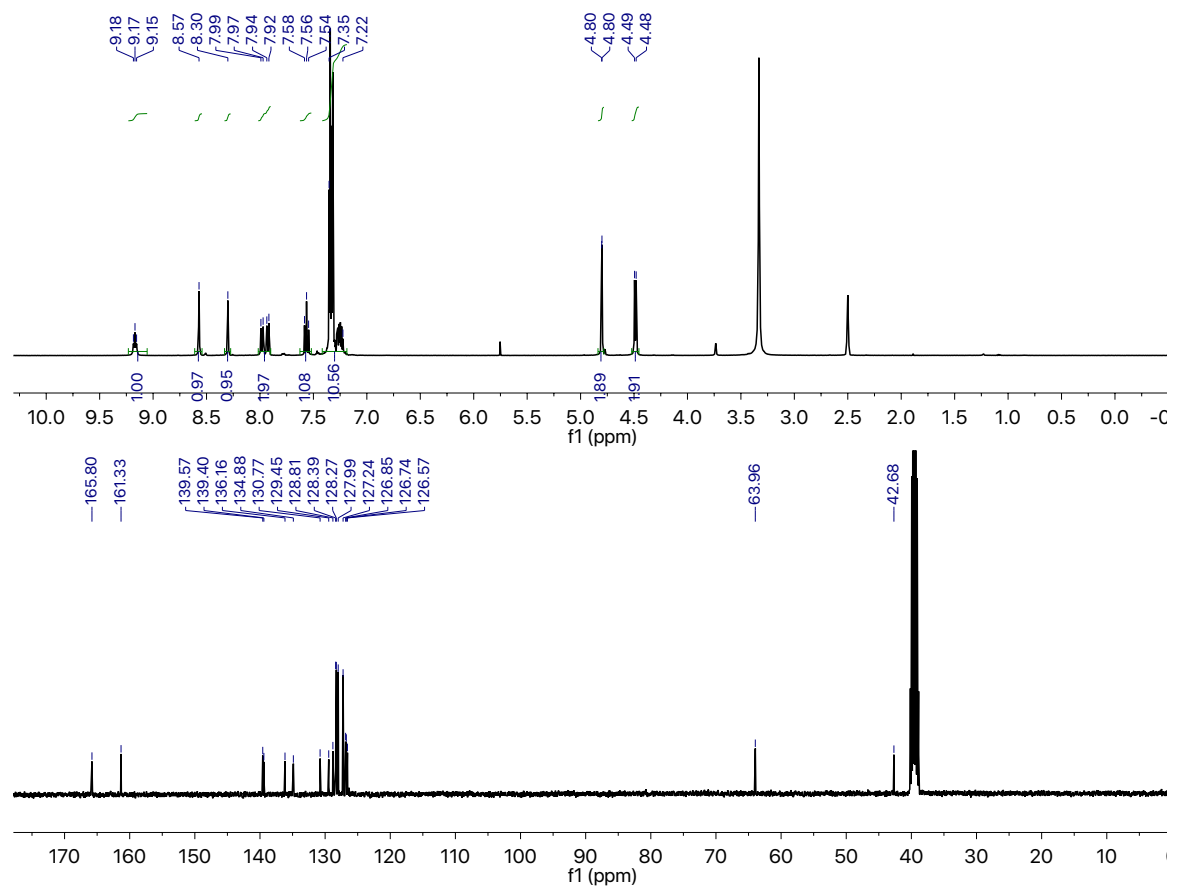

Figure S35. (Top) ${ }^{1} \mathrm{H}$ NMR spectrum (600 MHz, DMSO- $d_{6}$ ) of 4. (Bottom) ${ }^{13} \mathrm{C}$ NMR spectrum (151 MHz, DMSO- $\left.d_{6}\right)$ of compound 4. 


\section{Computational Results}

A conformer of 1 was subjected to macrocycle conformational search (MCS is implemented in the Maestro suite from Schrodinger) using parameters given below.

Force field: OPLS3e

Solvent: $\mathrm{H}_{2} \mathrm{O}$

Solvation model: GB/SA

Simulation

Cycles: 20000

LLMOD: 50000

Eigenvector: each new global

Torsional sampling: Extended

The starting geometry (see below) for MCS was obtained by MCMM conformational sampling (OPLS3/ $\mathrm{H}_{2} \mathrm{O} / 50000$ steps/Torsional sampling; Maestro). Importantly, MCS resulted in generating a conformer that was $>5 \mathrm{kcal} / \mathrm{mol}$ more stable than those generated by Monte Carlo methods (despite the starting geometry of $\mathbf{1}$ being used in such conformational sampling).

Starting conformer of $\mathbf{1}$ from

MCMM and subjected to MCS

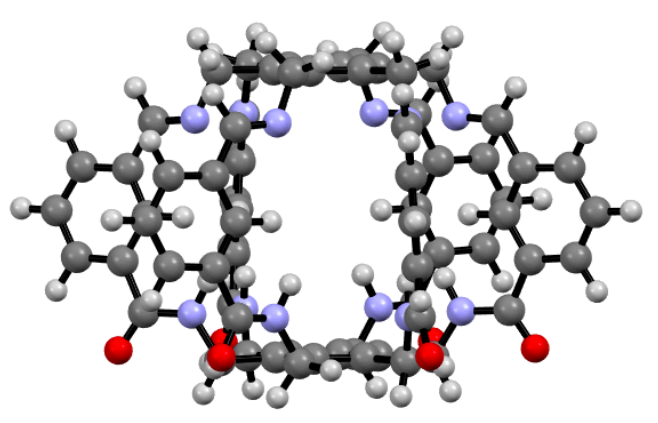

Energy-minimized 1 from MCS

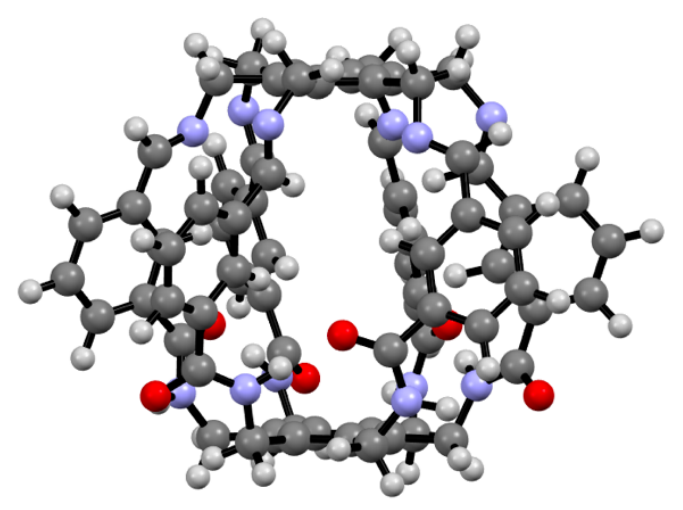


A conformer of $\left[\mathbf{C O}_{3} \subset \mathbf{1}\right]^{2-}$ was first constructed by using Maestro conformational search interface and docking a carbonate anion in the cavity of 1 . The carbon from $\mathrm{CO}_{3}{ }^{2-}$ was constrained to be within $3 \pm 2 \AA$ from $\mathbf{C}-\mathrm{H}_{\mathrm{C}}$ of the side benzene rings. Conformational sampling (MCMM; OPLS3/H $\mathrm{H}_{2} \mathrm{O} / 50000$ steps/torsional sampling) of such $\left[\mathbf{C O}_{3} \subset \mathbf{1}\right]^{2-}$ complex resulted in the most stable conformer (see below) having carbonate at the bottom of the cage forming six hydrogen bonds with $\mathrm{N}-\mathrm{H}_{\mathrm{G}}$ groups.

Energy-minimized

$\left[\mathrm{CO}_{3} \mathrm{I} \mathbf{1}\right]^{2-}$ from

MCMM/OPLS3e

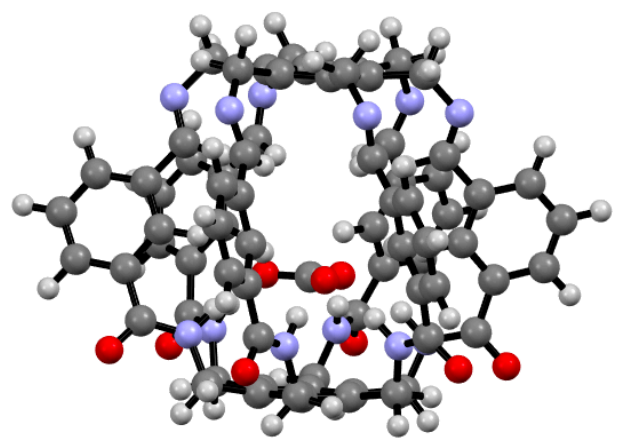

Energy minimized $\mathbf{1}$ and $\left[\mathbf{C O}_{3} \subset \mathbf{1}\right]^{2-}$ (see above) were further optimized using the Gaussian 16 software at the B3LYP/6-31G* level of theory (Figure S36). The resulting structures were subjected to frequency calculations at the same level of theory. After confirming that the structures were ground states, the geometries of these complexes were re-optimized at the M06-2X/6$311++\mathrm{G}^{* *}$ level of theory. Frequency calculations were also attempted at this level of theory albeit we found for them to be computationally costly.

(a)
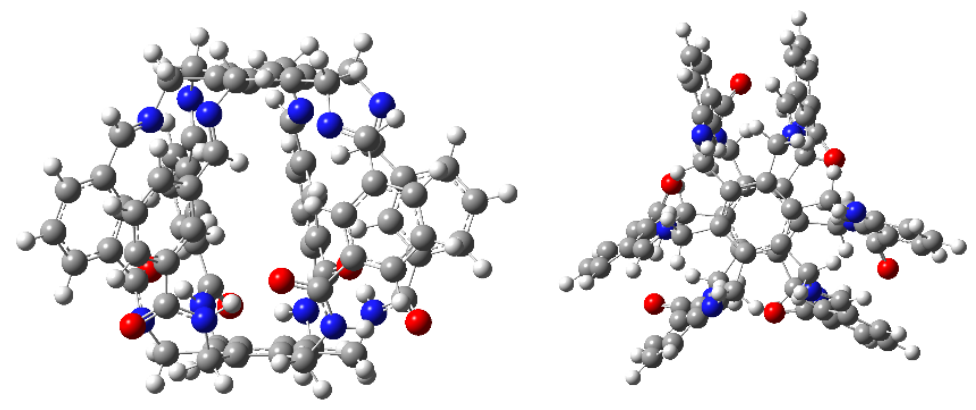
(b)
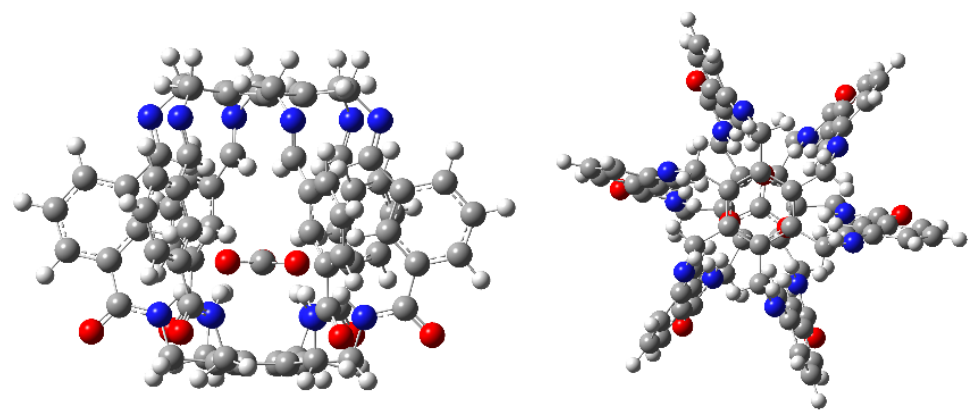

Figure S36. Side and top views of B3LYP/6-31G* optimized structures of 1 (a) and (b) $\left[\mathrm{CO}_{3} \subset \mathbf{1}\right]^{2-}$.

(a)
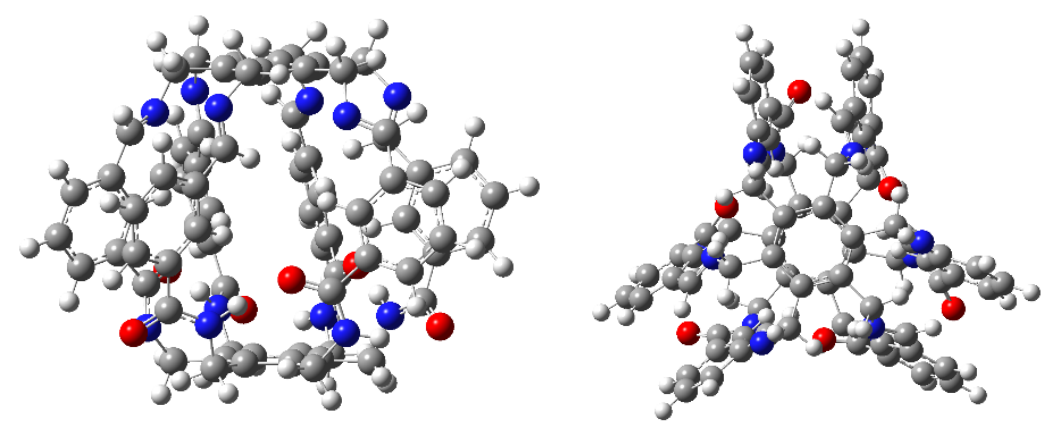

(b)
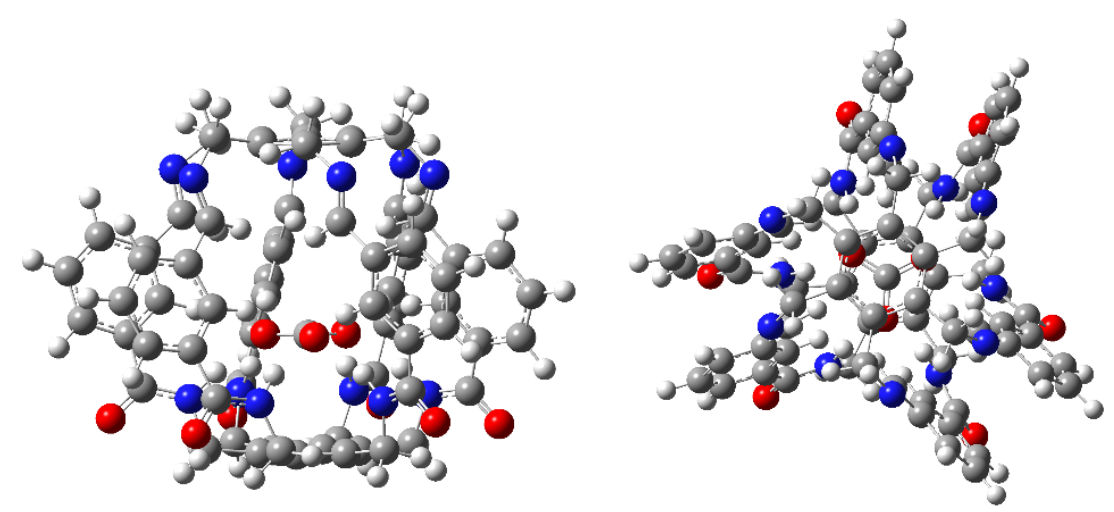

Figure S37. Side and top views of M06-2X/6-311++G** optimized structures of 1 (a) and (b) $\left[\mathrm{CO}_{3} \subset 1\right]^{2-}$. 


\begin{tabular}{|c|c|c|c|}
\hline \multicolumn{4}{|c|}{ B3LYP/6-31G* Optimized Structures: } \\
\hline \multicolumn{4}{|c|}{$\overline{\mathrm{E}(\mathrm{RB} 3 \mathrm{LYP})}=-3888.220029$} \\
\hline \multicolumn{4}{|c|}{ Number of imaginary frequencies $=0$} \\
\hline \multicolumn{4}{|c|}{ Cartesian Coordinates: } \\
\hline $\mathrm{C}$ & 0.27813600 & 1.26094000 & 4.23741300 \\
\hline $\mathrm{C}$ & -0.09974000 & -1.54039100 & 4.16595100 \\
\hline $\mathrm{C}$ & 1.39552300 & 0.39429000 & 4.19903300 \\
\hline $\mathrm{C}$ & -1.02720500 & 0.72013500 & 4.26229500 \\
\hline $\mathrm{C}$ & -1.22013800 & -0.68000400 & 4.20413400 \\
\hline $\mathrm{C}$ & 1.20955800 & -1.00538400 & 4.14109400 \\
\hline $\mathrm{C}$ & 0.48909900 & 2.78473100 & 4.35549400 \\
\hline $\mathrm{C}$ & 2.80483000 & 0.98237000 & 4.26037900 \\
\hline $\mathrm{C}$ & 2.42825000 & -1.95130400 & 4.15511300 \\
\hline $\mathrm{C}$ & -0.29159400 & -3.05642800 & 4.19050900 \\
\hline $\mathrm{C}$ & -2.64535700 & -1.26497600 & 4.28625300 \\
\hline $\mathrm{C}$ & -2.24007400 & 1.64103500 & 4.39117800 \\
\hline $\mathrm{N}$ & 2.57980500 & -2.88215800 & 3.03587700 \\
\hline $\mathrm{N}$ & 3.42097800 & 1.07190700 & 2.94334600 \\
\hline $\mathrm{N}$ & 1.21645400 & 3.45619200 & 3.27742500 \\
\hline $\mathrm{N}$ & -2.62892000 & 2.21985000 & 3.11213900 \\
\hline $\mathrm{N}$ & -3.59363400 & -0.89639600 & 3.23405600 \\
\hline $\mathrm{N}$ & -0.60194400 & -3.59264000 & 2.87201300 \\
\hline $\mathrm{C}$ & -3.90097200 & 2.21340600 & 2.65692100 \\
\hline $\mathrm{C}$ & 0.62985500 & 3.80418000 & 2.10666500 \\
\hline $\mathrm{C}$ & 4.02279600 & 2.19196800 & 2.48645500 \\
\hline $\mathrm{C}$ & & -2.50941000 & 1.84127600 \\
\hline $\mathrm{C}$ & 0.03741200 & -4.65774100 & 2.34081500 \\
\hline $\mathrm{C}$ & -3.60390800 & -1.49413800 & 2.01817800 \\
\hline $\mathrm{O}$ & -2.79715400 & -2.37493100 & 1.68928900 \\
\hline $\mathrm{O}$ & -4.84872800 & 1.74156600 & 3.31223300 \\
\hline $\mathrm{O}$ & -0.55500500 & 3.55694400 & 1.84248500 \\
\hline $\mathrm{O}$ & 4.12871900 & 3.22671300 & 3.17081800 \\
\hline $\mathrm{O}$ & 3.45815100 & -1.35053600 & 1.59039300 \\
\hline $\mathrm{O}$ & 0.92082100 & -5.28703000 & 2.95226500 \\
\hline $\mathrm{C}$ & 4.50939300 & 2.14615800 & 1.06675800 \\
\hline $\mathrm{C}$ & 5.36617900 & 2.25372900 & -1.59667000 \\
\hline $\mathrm{C}$ & 5.64297000 & 2.88963900 & 0.72060300 \\
\hline $\mathrm{C}$ & 3.80353100 & 1.46212000 & 0.06737600 \\
\hline $\mathrm{C}$ & 4.20510000 & 1.53236700 & -1.27192100 \\
\hline $\mathrm{C}$ & 6.08238300 & 2.91739000 & -0.60448300 \\
\hline $\mathrm{C}$ & 1.49252500 & 4.49065100 & 1.09151400 \\
\hline $\mathrm{C}$ & 3.10547300 & 5.58514600 & -0.90760500 \\
\hline $\mathrm{C}$ & 2.48600800 & 5.42381900 & 1.42348000 \\
\hline $\mathrm{C}$ & 1.28987600 & 4.14068900 & -0.24335500 \\
\hline
\end{tabular}




\begin{tabular}{|c|c|c|c|}
\hline $\mathrm{C}$ & 2.11697000 & 4.65152100 & -1.25019100 \\
\hline $\mathrm{C}$ & 3.26944800 & 5.98779400 & 0.41756600 \\
\hline $\mathrm{C}$ & -4.10744400 & 2.75553800 & 1.27206400 \\
\hline $\mathrm{C}$ & -4.63396900 & 3.62760900 & -1.33590400 \\
\hline $\mathrm{C}$ & -5.31685600 & 3.39212900 & 0.97257800 \\
\hline $\mathrm{C}$ & -3.16597900 & 2.55251400 & 0.25360400 \\
\hline $\mathrm{C}$ & -3.43016300 & 2.95777100 & -1.06011300 \\
\hline $\mathrm{C}$ & -5.56297500 & 3.85013100 & -0.32333200 \\
\hline $\mathrm{C}$ & -4.63253100 & -1.02109700 & 1.03627000 \\
\hline $\mathrm{C}$ & -6.39202600 & -0.03603000 & -0.89508200 \\
\hline $\mathrm{C}$ & -5.93638600 & -0.65079300 & 1.39801500 \\
\hline $\mathrm{C}$ & -4.23184300 & -0.93018800 & -0.29661600 \\
\hline $\mathrm{C}$ & -5.09038500 & -0.40132400 & -1.26713700 \\
\hline $\mathrm{C}$ & -6.81905600 & -0.18591100 & 0.42411900 \\
\hline $\mathrm{C}$ & -0.33263400 & -5.01118700 & 0.92921600 \\
\hline $\mathrm{C}$ & -0.83228200 & -5.72186400 & -1.73254500 \\
\hline $\mathrm{C}$ & -0.28003200 & -6.35299800 & 0.53629500 \\
\hline $\mathrm{C}$ & -0.63058500 & -4.02656900 & -0.02294400 \\
\hline $\mathrm{C}$ & -0.85321200 & -4.36663200 & -1.36260000 \\
\hline $\mathrm{C}$ & -0.55746500 & -6.70504900 & -0.78614000 \\
\hline $\mathrm{C}$ & 3.20055200 & -3.56655300 & 0.78391500 \\
\hline $\mathrm{C}$ & 3.22142900 & -5.44506900 & -1.28176700 \\
\hline $\mathrm{C}$ & 3.53182400 & -4.90281300 & 1.05349900 \\
\hline $\mathrm{C}$ & 2.91844300 & -3.17382600 & -0.52432700 \\
\hline $\mathrm{C}$ & 2.88678300 & -4.11250900 & -1.56187700 \\
\hline $\mathrm{C}$ & 3.56775100 & -5.83023900 & 0.01315200 \\
\hline $\mathrm{C}$ & -1.05354700 & -3.29859800 & -2.36638500 \\
\hline $\mathrm{C}$ & -4.59248100 & -0.11333600 & -2.62508900 \\
\hline $\mathrm{C}$ & -2.46842600 & 2.63094600 & -2.13556200 \\
\hline $\mathrm{C}$ & 2.03491900 & 4.11973500 & -2.62329000 \\
\hline $\mathrm{C}$ & 3.37812000 & 0.89460700 & -2.31966600 \\
\hline $\mathrm{C}$ & 2.38494100 & -3.73220700 & -2.89540900 \\
\hline $\mathrm{N}$ & 2.22532200 & -2.51779100 & -3.24910000 \\
\hline $\mathrm{N}$ & -2.75679900 & 2.83952400 & -3.35989600 \\
\hline $\mathrm{N}$ & 3.62589100 & 1.08206100 & -3.55625700 \\
\hline $\mathrm{N}$ & 1.06197000 & 3.40027600 & -3.02464400 \\
\hline $\mathrm{N}$ & -3.48463200 & -0.56867000 & -3.06174700 \\
\hline $\mathrm{N}$ & -1.09303700 & -3.56736600 & -3.61213000 \\
\hline $\mathrm{C}$ & -3.02115000 & -0.08719300 & -4.36673400 \\
\hline $\mathrm{C}$ & -1.77596400 & 2.56452500 & -4.41497400 \\
\hline $\mathrm{C}$ & 1.16762200 & 2.80046900 & -4.35836700 \\
\hline $\mathrm{C}$ & 2.83461900 & 0.40184400 & -4.58690200 \\
\hline $\mathrm{C}$ & 1.57231900 & -2.26800300 & -4.53793700 \\
\hline $\mathrm{C}$ & -1.34704400 & -2.50984100 & -4.59604600 \\
\hline $\mathrm{C}$ & 0.70606600 & -1.01256900 & -4.45733800 \\
\hline $\mathrm{C}$ & -0.89401800 & 1.31112400 & -4.34157400 \\
\hline
\end{tabular}




\begin{tabular}{lrrr}
$\mathrm{C}$ & -0.70136000 & -1.12809400 & -4.42824800 \\
$\mathrm{C}$ & 1.31555900 & 0.25984300 & -4.42443200 \\
$\mathrm{C}$ & 0.51265400 & 1.42065100 & -4.37097700 \\
$\mathrm{C}$ & -1.49867400 & 0.03509800 & -4.37491700 \\
$\mathrm{H}$ & -0.46961200 & 3.29061900 & 4.44219200 \\
$\mathrm{H}$ & 1.03518300 & 3.00312900 & 5.27974600 \\
$\mathrm{H}$ & 2.80741900 & 1.98357700 & 4.68566200 \\
$\mathrm{H}$ & 3.43787400 & 0.39038100 & 4.93150500 \\
$\mathrm{H}$ & 3.34944200 & -1.37550000 & 4.20421800 \\
$\mathrm{H}$ & 2.40053200 & -2.56246900 & 5.06387300 \\
$\mathrm{H}$ & 0.59823200 & -3.57126200 & 4.54607800 \\
$\mathrm{H}$ & -1.07860300 & -3.33129300 & 4.90229500 \\
$\mathrm{H}$ & -2.60465400 & -2.35159700 & 4.29784200 \\
$\mathrm{H}$ & -3.10445100 & -0.96571900 & 5.23483500 \\
$\mathrm{H}$ & -3.10774500 & 1.11531300 & 4.78364200 \\
$\mathrm{H}$ & -2.04106600 & 2.43677800 & 5.11833600 \\
$\mathrm{H}$ & 2.17527300 & -3.81669900 & 3.11598400 \\
$\mathrm{H}$ & 3.44371300 & 0.21183100 & 2.38660600 \\
$\mathrm{H}$ & 2.22852300 & 3.56586200 & 3.36186000 \\
$\mathrm{H}$ & -1.89693600 & 2.70756200 & 2.58614600 \\
$\mathrm{H}$ & -4.19442800 & -0.08277900 & 3.37721600 \\
$\mathrm{H}$ & -1.39081300 & -3.16621300 & 2.37591700 \\
$\mathrm{H}$ & 6.16607700 & 3.44036000 & 1.49598000 \\
$\mathrm{H}$ & 2.91270900 & 0.89738400 & 0.32247300 \\
$\mathrm{H}$ & 6.97867000 & 3.47464100 & -0.86423000 \\
$\mathrm{H}$ & 5.67731500 & 2.28998600 & -2.63579200 \\
$\mathrm{H}$ & 2.64952600 & 5.70592200 & 2.45844800 \\
$\mathrm{H}$ & 0.52192000 & 3.42195400 & -0.50275400 \\
$\mathrm{H}$ & 4.03089300 & 6.71895900 & 0.67292500 \\
$\mathrm{H}$ & 3.75694900 & 5.98487000 & -1.68140200 \\
$\mathrm{H}$ & -6.05249300 & 3.51872300 & 1.76060600 \\
$\mathrm{H}$ & -2.23266700 & 2.04353900 & 0.47144800 \\
$\mathrm{H}$ & -6.49259100 & 4.36769200 & -0.54530600 \\
$\mathrm{H}$ & -4.82286000 & 3.95079800 & -2.35461000 \\
$\mathrm{H}$ & -6.25974000 & -0.72130400 & 2.43142000 \\
$\mathrm{H}$ & -3.22629100 & -1.21775500 & -0.57911200 \\
$\mathrm{H}$ & -7.83212600 & 0.09004400 & 0.70186900 \\
$\mathrm{H}$ & -7.06590200 & 0.38067200 & -1.64020500 \\
$\mathrm{H}$ & -0.01952800 & -7.10587300 & 1.27351200 \\
$\mathrm{H}$ & -54153000 & -7.75112100 & -1.08076900 \\
$\mathrm{H}$ & & -2.98131600 & 0.26748600 \\
$\mathrm{H}$ & -5695000 & -5.21825200 & 2.06704100 \\
$\mathrm{H}$ & -2.14209100 & -0.73559200 \\
$\mathrm{H}$ & -6.86237900 & 0.21966600 \\
$\mathrm{H}$ & -6.18377700 & -2.07963200 \\
\hline
\end{tabular}




$\begin{array}{lrrr}\mathrm{H} & -1.14502700 & -2.27712400 & -1.97316200 \\ \mathrm{H} & -5.21250600 & 0.57952300 & -3.21600000 \\ \mathrm{H} & -1.51611600 & 2.18823400 & -1.81386300 \\ \mathrm{H} & 2.90743700 & 4.33065000 & -3.26194300 \\ \mathrm{H} & 2.54202200 & 0.27646700 & -1.96577600 \\ \mathrm{H} & 2.09200600 & -4.57264900 & -3.54462500 \\ \mathrm{H} & -3.33940400 & -0.80359100 & -5.13413000 \\ \mathrm{H} & -3.49457700 & 0.86608600 & -4.62444900 \\ \mathrm{H} & -2.34221200 & 2.52466300 & -5.35454100 \\ \mathrm{H} & -1.16053600 & 3.46241900 & -4.48534400 \\ \mathrm{H} & 3.02516300 & 0.94201700 & -5.52333300 \\ \mathrm{H} & 3.29918700 & -0.57653600 & -4.71679100 \\ \mathrm{H} & 2.34930500 & -2.13375800 & -5.30062500 \\ \mathrm{H} & -1.03166900 & -2.91449600 & -5.56650900 \\ \mathrm{H} & 2.21235400 & 2.74397700 & -4.68185000 \\ \mathrm{H} & 0.98179900 & -3.13470900 & -4.85322400 \\ \mathrm{H} & -2.43246400 & -2.42063100 & -4.65815900 \\ \mathrm{H} & 0.66082200 & 3.45768700 & -5.07574400\end{array}$

\section{Carbonate inside of Molecule 1:}

$\mathrm{E}(\mathrm{RB} 3 \mathrm{LYP})=-4152.159580$

Number of imaginary frequencies $=0$

Cartesian Coordinates:

$\begin{array}{lrrr}\mathrm{C} & -0.06069600 & -0.60413700 & 4.54394000 \\ \mathrm{C} & 1.52415800 & -2.64735100 & 3.41873600 \\ \mathrm{C} & 1.32481300 & -0.40830400 & 4.37171100 \\ \mathrm{C} & -0.65265000 & -1.82387300 & 4.15636300 \\ \mathrm{C} & 0.13844000 & -2.84437600 & 3.59029300 \\ \mathrm{C} & 2.11729500 & -1.42838300 & 3.80612900 \\ \mathrm{C} & -0.94283200 & 0.54721400 & 5.00756200 \\ \mathrm{C} & 1.93103100 & 0.95801000 & 4.66040800 \\ \mathrm{C} & 3.57899000 & -1.15302200 & 3.48010000 \\ \mathrm{C} & 2.35731800 & -3.68655700 & 2.68164000 \\ \mathrm{C} & -0.51944700 & -4.09755300 & 3.02871300 \\ \mathrm{C} & -2.16521400 & -1.98876200 & 4.20800700 \\ \mathrm{~N} & 3.68252800 & -0.28353500 & 2.30836400 \\ \mathrm{~N} & 1.55438000 & 1.90299200 & 3.61263400 \\ \mathrm{~N} & -1.65153500 & 1.13361800 & 3.87022500 \\ \mathrm{~N} & -2.72964100 & -1.84113800 & 2.86927200 \\ \mathrm{~N} & -0.60740200 & -4.01527700 & 1.57087000 \\ \mathrm{~N} & 2.60869300 & -3.24569100 & 1.31233500 \\ \mathrm{C} & -3.97851700 & -2.28706200 & 2.60347200 \\ \mathrm{C} & -2.60108700 & 2.07434500 & 4.08577700 \\ \mathrm{C} & 1.67285200 & 3.23403700 & 3.82102000 \\ \mathrm{C} & 4.89108700 & 0.20397000 & 1.94141800 \\ \mathrm{C} & 3.59647000 & -3.81430300 & 0.58426000\end{array}$




\begin{tabular}{|c|c|c|c|}
\hline $\mathrm{C}$ & -1.02201100 & -5.09264900 & 0.86351100 \\
\hline $\mathrm{O}$ & -1.29952300 & -6.17009900 & 1.40665800 \\
\hline $\mathrm{O}$ & -4.67867000 & -2.84999200 & 3.45573900 \\
\hline $\mathrm{O}$ & -2.92298300 & 2.43624300 & 5.22520200 \\
\hline $\mathrm{O}$ & 2.07431500 & 3.70578700 & 4.89327100 \\
\hline $\mathrm{O}$ & 5.92036400 & -0.03229800 & 2.58771700 \\
\hline $\mathrm{O}$ & 4.33365200 & -4.69856000 & 1.04043200 \\
\hline $\mathrm{C}$ & 1.28156900 & 4.14733500 & 2.68070100 \\
\hline $\mathrm{C}$ & 0.59712900 & 5.99508900 & 0.67758900 \\
\hline $\mathrm{C}$ & 1.45265200 & 5.52064000 & 2.88724300 \\
\hline $\mathrm{C}$ & 0.76231100 & 3.70224400 & 1.45682600 \\
\hline $\mathrm{C}$ & 0.41708300 & 4.62016300 & 0.45476500 \\
\hline $\mathrm{C}$ & 1.11461300 & 6.43789900 & 1.88997800 \\
\hline $\mathrm{C}$ & -3.26756300 & 2.68280000 & 2.87147800 \\
\hline $\mathrm{C}$ & -4.59348500 & 3.92773400 & 0.72631500 \\
\hline $\mathrm{C}$ & -4.24932800 & 3.65235000 & 3.10488000 \\
\hline $\mathrm{C}$ & -2.95362700 & 2.33983800 & 1.54983100 \\
\hline $\mathrm{C}$ & -3.61034400 & 2.95688600 & 0.47603300 \\
\hline $\mathrm{C}$ & -4.90738400 & 4.26929000 & 2.03797700 \\
\hline $\mathrm{C}$ & -4.49984300 & -2.07955400 & 1.19898500 \\
\hline $\mathrm{C}$ & -5.63256600 & -1.78424700 & -1.35530100 \\
\hline $\mathrm{C}$ & -5.81010500 & -2.50026900 & 0.94580000 \\
\hline $\mathrm{C}$ & -3.75539500 & -1.50643900 & 0.15829800 \\
\hline $\mathrm{C}$ & -4.31519800 & -1.35871600 & -1.11871700 \\
\hline $\mathrm{C}$ & -6.37294200 & -2.35060200 & -0.32341900 \\
\hline $\mathrm{C}$ & -1.14096100 & -4.93775700 & -0.63676400 \\
\hline $\mathrm{C}$ & -1.43427900 & -4.81701200 & -3.43120300 \\
\hline $\mathrm{C}$ & -1.56866600 & -6.05757600 & -1.35885500 \\
\hline $\mathrm{C}$ & -0.85983500 & -3.75185700 & -1.32785000 \\
\hline $\mathrm{C}$ & -1.00455500 & -3.68473800 & -2.72054700 \\
\hline $\mathrm{C}$ & -1.71317900 & -5.99593300 & -2.74710200 \\
\hline $\mathrm{C}$ & 3.78110500 & -3.31809900 & -0.83244700 \\
\hline $\mathrm{C}$ & 4.27269000 & -2.52117400 & -3.48152500 \\
\hline $\mathrm{C}$ & 4.77201500 & -3.94622900 & -1.59495700 \\
\hline $\mathrm{C}$ & 3.03313800 & -2.28156400 & -1.40841000 \\
\hline $\mathrm{C}$ & 3.27580300 & -1.87863400 & -2.72926600 \\
\hline $\mathrm{C}$ & 5.01372000 & -3.55104200 & -2.91235400 \\
\hline $\mathrm{C}$ & 4.94854000 & 1.05927300 & 0.69475700 \\
\hline $\mathrm{C}$ & 5.23686100 & 2.65149200 & -1.60555500 \\
\hline $\mathrm{C}$ & 6.20227000 & 1.55881100 & 0.32466600 \\
\hline $\mathrm{C}$ & 3.83536300 & 1.36480700 & -0.09925800 \\
\hline $\mathrm{C}$ & 3.97224400 & 2.15731000 & -1.24742200 \\
\hline $\mathrm{C}$ & 6.34349000 & 2.35015500 & -0.81802400 \\
\hline $\mathrm{C}$ & 2.48253700 & -0.77086500 & -3.29254100 \\
\hline $\mathrm{C}$ & -0.69221100 & -2.41164900 & -3.3946920 \\
\hline $\mathrm{C}$ & -3.49344600 & -0.77071700 & -2.19239700 \\
\hline
\end{tabular}




\begin{tabular}{|c|c|c|c|}
\hline $\mathrm{C}$ & -3.24083800 & 2.55394700 & -0.89285400 \\
\hline $\mathrm{C}$ & -0.14629100 & 4.11411200 & -0.81027000 \\
\hline $\mathrm{C}$ & 2.76602800 & 2.44798200 & -2.04322700 \\
\hline $\mathrm{N}$ & 2.79767000 & 3.15136600 & -3.10942000 \\
\hline $\mathrm{N}$ & -3.94327300 & -0.59447300 & -3.37480800 \\
\hline $\mathrm{N}$ & -0.47185600 & 4.89181800 & -1.76979300 \\
\hline $\mathrm{N}$ & -3.77693200 & 3.07098900 & -1.93101300 \\
\hline $\mathrm{N}$ & -0.80462300 & -2.25603400 & -4.65788000 \\
\hline $\mathrm{N}$ & 2.64182900 & -0.36051500 & -4.49162300 \\
\hline $\mathrm{C}$ & -0.40113100 & -0.99106500 & -5.27868400 \\
\hline $\mathrm{C}$ & -3.07001400 & -0.09634400 & -4.43783700 \\
\hline $\mathrm{C}$ & -3.42585600 & 2.57004100 & -3.26302300 \\
\hline $\mathrm{C}$ & -1.11641000 & 4.36240000 & -2.97188200 \\
\hline $\mathrm{C}$ & 1.55192000 & 3.47250200 & -3.81189200 \\
\hline $\mathrm{C}$ & 1.90375300 & 0.80259600 & -4.98486900 \\
\hline $\mathrm{C}$ & 0.38147800 & 2.47879700 & -3.80779300 \\
\hline $\mathrm{C}$ & -1.83916800 & 0.75755100 & -4.10669600 \\
\hline $\mathrm{C}$ & 0.55430900 & 1.19374000 & -4.36876200 \\
\hline $\mathrm{C}$ & -0.90227900 & 2.90474700 & -3.39978000 \\
\hline $\mathrm{C}$ & -2.01185900 & 2.04241300 & -3.54515000 \\
\hline $\mathrm{C}$ & -0.55534900 & 0.33157000 & -4.51450200 \\
\hline $\mathrm{H}$ & -1.67967600 & 0.21732300 & 5.74796400 \\
\hline $\mathrm{H}$ & -0.36061700 & 1.32505600 & 5.50636300 \\
\hline $\mathrm{H}$ & 1.59148700 & 1.36010200 & 5.61922300 \\
\hline $\mathrm{H}$ & 3.02033400 & 0.90247100 & 4.73548000 \\
\hline $\mathrm{H}$ & 4.09577400 & -0.67444300 & 4.31902600 \\
\hline $\mathrm{H}$ & 4.13021300 & -2.07667500 & 3.29071400 \\
\hline $\mathrm{H}$ & 3.32275000 & -3.85404500 & 3.16762600 \\
\hline $\mathrm{H}$ & 1.86121400 & -4.66077700 & 2.67225600 \\
\hline $\mathrm{H}$ & 0.03987900 & -5.00065500 & 3.29602600 \\
\hline $\mathrm{H}$ & -1.52034200 & -4.24536400 & 3.44004500 \\
\hline $\mathrm{H}$ & -2.45518200 & -2.97066400 & 4.59280200 \\
\hline $\mathrm{H}$ & -2.62206200 & -1.26211800 & 4.88518100 \\
\hline $\mathrm{H}$ & 2.81630300 & -0.09307900 & 1.78462300 \\
\hline $\mathrm{H}$ & 1.29492500 & 1.49482200 & 2.70216800 \\
\hline $\mathrm{H}$ & -1.37495000 & 0.81936600 & 2.92925100 \\
\hline $\mathrm{H}$ & -2.16582500 & -1.30472000 & 2.19316900 \\
\hline $\mathrm{H}$ & -0.36838000 & -3.11361700 & 1.13406000 \\
\hline $\mathrm{H}$ & 1.94015100 & -2.56471600 & 0.92239100 \\
\hline $\mathrm{H}$ & 1.85122800 & 5.84028900 & 3.84456200 \\
\hline $\mathrm{H}$ & 0.62846800 & 2.63958700 & 1.25961400 \\
\hline $\mathrm{H}$ & 1.25323000 & 7.50284300 & 2.06493200 \\
\hline $\mathrm{H}$ & 0.32060800 & 6.68921200 & -0.11000900 \\
\hline $\mathrm{H}$ & -4.47565400 & 3.90431400 & 4.13589600 \\
\hline $\mathrm{H}$ & -2.20001300 & 1.58480600 & 1.33132800 \\
\hline $\mathrm{H}$ & -5.66839200 & 5.02157100 & 2.23533900 \\
\hline
\end{tabular}




$\begin{array}{lrrr}\mathrm{H} & -5.09231700 & 4.39492200 & -0.11738500 \\ \mathrm{H} & -6.36357100 & -2.94554800 & 1.76610100 \\ \mathrm{H} & -2.73729200 & -1.15759800 & 0.32542400 \\ \mathrm{H} & -7.39309700 & -2.68240400 & -0.50540400 \\ \mathrm{H} & -6.04599900 & -1.66355200 & -2.35183800 \\ \mathrm{H} & -1.78284900 & -6.96515200 & -0.80375600 \\ \mathrm{H} & -0.51805600 & -2.86348100 & -0.79904300 \\ \mathrm{H} & -2.04695500 & -6.87495100 & -3.29476500 \\ \mathrm{H} & -1.54039900 & -4.74701200 & -4.50951500 \\ \mathrm{H} & 5.34068100 & -4.74190700 & -1.12484200 \\ \mathrm{H} & 2.24643500 & -1.78062500 & -0.84609300 \\ \mathrm{H} & 5.78752400 & -4.04880000 & -3.49321000 \\ \mathrm{H} & 4.44661800 & -2.19195400 & -4.50130400 \\ \mathrm{H} & 7.05128300 & 1.30863800 & 0.95258900 \\ \mathrm{H} & 2.84378000 & 0.99898900 & 0.16265100 \\ \mathrm{H} & 7.32494400 & 2.73107700 & -1.09308300 \\ \mathrm{H} & 5.32419400 & 3.26403400 & -2.49779600 \\ \mathrm{H} & 1.75362500 & -0.32376200 & -2.60358900 \\ \mathrm{H} & -0.35447100 & -1.60947300 & -2.72507300 \\ \mathrm{H} & -2.46888600 & -0.50422800 & -1.90073200 \\ \mathrm{H} & -2.47002800 & 1.77369900 & -0.94811300 \\ \mathrm{H} & -0.27062900 & 3.02425100 & -0.86068400 \\ \mathrm{H} & 1.83926400 & 2.01311200 & -1.64574900 \\ \mathrm{H} & 0.63922000 & -1.12956600 & -5.58366100 \\ \mathrm{H} & -0.97341800 & -0.91115000 & -6.21395400 \\ \mathrm{H} & -2.76995100 & -0.98297800 & -5.00318500 \\ \mathrm{H} & -3.71255800 & 0.47944000 & -5.11887300 \\ \mathrm{H} & -2.18338500 & 4.56054900 & -2.83751400 \\ \mathrm{H} & -0.80152800 & 5.01182000 & -3.80092100 \\ \mathrm{H} & 1.22732900 & 4.43719600 & -3.41369500 \\ \mathrm{H} & 2.60435900 & 1.63925400 & -4.91481600 \\ \mathrm{H} & -3.62659700 & 3.39301200 & -3.96378100 \\ \mathrm{H} & 1.82965200 & 3.66473700 & -4.85808800 \\ \mathrm{H} & 1.75346300 & 0.63766800 & -6.06115600 \\ \mathrm{H} & -4.16694700 & 1.80103600 & -3.49520300 \\ \mathrm{O} & 0.18473600 & -0.41131600 & 1.01036300 \\ \mathrm{O} & -1.03645500 & -0.13127300 & 1.34679600 \\ & 1.12539600 & 0.46264300 & 1.19579700 \\ \mathrm{O} & 0.46490800 & -1.56411300 & 0.48553700\end{array}$

M06-2X/6-311++G** Optimized Structures:

Molecule 1:

$\mathrm{E}(\mathrm{RM} 062 \mathrm{X})=-3887.785143$

Cartesian Coordinates:

$\begin{array}{llll}\text { C } & 0.20307500 & 1.26158900 & 4.25412100\end{array}$

C $\quad-0.02186100 \quad-1.53784300 \quad 4.18053900$ 


\begin{tabular}{|c|c|c|c|}
\hline $\mathrm{C}$ & 1.35828700 & 0.46143600 & 4.21827900 \\
\hline $\mathrm{C}$ & -1.06303600 & 0.65547500 & 4.27606300 \\
\hline $\mathrm{C}$ & -1.17917300 & -0.74408600 & 4.21620200 \\
\hline $\mathrm{C}$ & 1.24860100 & -0.93680200 & 4.15837700 \\
\hline $\mathrm{C}$ & 0.33004600 & 2.78644600 & 4.35112000 \\
\hline $\mathrm{C}$ & 2.72867400 & 1.11681200 & 4.25078800 \\
\hline $\mathrm{C}$ & 2.50887300 & -1.80983000 & 4.15098500 \\
\hline $\mathrm{C}$ & -0.13789700 & -3.05277500 & 4.17135800 \\
\hline $\mathrm{C}$ & -2.56339800 & -1.40076100 & 4.27130400 \\
\hline $\mathrm{C}$ & -2.31552700 & 1.51065700 & 4.37016400 \\
\hline $\mathrm{N}$ & 2.62581600 & -2.77345700 & 3.06634200 \\
\hline $\mathrm{N}$ & 3.28257100 & 1.20992600 & 2.91105200 \\
\hline $\mathrm{N}$ & 1.10300900 & 3.44273500 & 3.30672100 \\
\hline $\mathrm{N}$ & -2.67696300 & 2.03336000 & 3.06389700 \\
\hline $\mathrm{N}$ & -3.51979700 & -0.98739300 & 3.25492500 \\
\hline $\mathrm{N}$ & -0.41429200 & -3.53598200 & 2.82961500 \\
\hline $\mathrm{C}$ & -3.94668800 & 2.05594100 & 2.61582800 \\
\hline $\mathrm{C}$ & 0.61027800 & 3.59586800 & 2.05992700 \\
\hline $\mathrm{C}$ & 3.90954300 & 2.31289100 & 2.45935000 \\
\hline $\mathrm{C}$ & 2.92853900 & -2.38419700 & 1.81036000 \\
\hline $\mathrm{C}$ & 0.19578000 & -4.61649900 & 2.30634900 \\
\hline $\mathrm{C}$ & -3.41021700 & -1.40406500 & 1.97625000 \\
\hline $\mathrm{O}$ & -2.49197300 & -2.12466600 & 1.59472800 \\
\hline $\mathrm{O}$ & -4.89849000 & 1.66592600 & 3.29206800 \\
\hline $\mathrm{O}$ & -0.49443900 & 3.17188900 & 1.73172400 \\
\hline $\mathrm{O}$ & 4.09058900 & 3.30912500 & 3.15931300 \\
\hline $\mathrm{O}$ & 3.09441900 & -1.20564500 & 1.50796200 \\
\hline $\mathrm{O}$ & 1.00772200 & -5.29310400 & 2.93730400 \\
\hline $\mathrm{C}$ & 4.35091800 & 2.26967800 & 1.02466100 \\
\hline $\mathrm{C}$ & 5.21530800 & 2.30514200 & -1.62321000 \\
\hline $\mathrm{C}$ & 5.45423300 & 3.03567300 & 0.66008300 \\
\hline $\mathrm{C}$ & 3.66844100 & 1.53060000 & 0.05443600 \\
\hline $\mathrm{C}$ & 4.08269000 & 1.56081100 & -1.27514800 \\
\hline $\mathrm{C}$ & 5.89717600 & 3.03404500 & -0.66023400 \\
\hline $\mathrm{C}$ & 1.49511700 & 4.28669900 & 1.07321000 \\
\hline $\mathrm{C}$ & 3.23103400 & 5.31558600 & -0.83439700 \\
\hline $\mathrm{C}$ & 2.46200500 & 5.22526200 & 1.44381700 \\
\hline $\mathrm{C}$ & 1.36398800 & 3.91119200 & -0.25674600 \\
\hline $\mathrm{C}$ & 2.24625700 & 4.40542000 & -1.21474900 \\
\hline $\mathrm{C}$ & 3.31524600 & 5.75105400 & 0.48419700 \\
\hline $\mathrm{C}$ & -4.13297900 & 2.55979500 & 1.21343200 \\
\hline $\mathrm{C}$ & -4.60319600 & 3.47215100 & -1.37622400 \\
\hline $\mathrm{C}$ & -5.34864500 & 3.15689600 & 0.89290700 \\
\hline $\mathrm{C}$ & -3.15425700 & 2.40627800 & 0.22752300 \\
\hline $\mathrm{C}$ & -3.39149900 & 2.84063400 & -1.07455900 \\
\hline $\mathrm{C}$ & -5.57223200 & 3.63202500 & -0.39698000 \\
\hline
\end{tabular}




\begin{tabular}{|c|c|c|c|}
\hline $\mathrm{C}$ & -4.45403500 & -0.91603600 & 1.02436700 \\
\hline $\mathrm{C}$ & -6.21998600 & 0.20177200 & -0.80421600 \\
\hline $\mathrm{C}$ & -5.74894000 & -0.57468700 & 1.42405200 \\
\hline $\mathrm{C}$ & -4.06809800 & -0.75016000 & -0.29867000 \\
\hline $\mathrm{C}$ & -4.94083500 & -0.16863800 & -1.21568600 \\
\hline $\mathrm{C}$ & -6.63429500 & -0.03354500 & 0.50282400 \\
\hline $\mathrm{C}$ & -0.15175700 & -4.93281800 & 0.87992400 \\
\hline $\mathrm{C}$ & -0.71898800 & -5.61727900 & -1.76026500 \\
\hline $\mathrm{C}$ & -0.06957700 & -6.26000800 & 0.46900800 \\
\hline $\mathrm{C}$ & -0.50550500 & -3.94247400 & -0.04067600 \\
\hline $\mathrm{C}$ & -0.76968100 & -4.27527900 & -1.36733700 \\
\hline $\mathrm{C}$ & -0.37482600 & -6.60190500 & -0.84609100 \\
\hline $\mathrm{C}$ & 3.02195800 & -3.46499900 & 0.78225500 \\
\hline $\mathrm{C}$ & 2.92094200 & -5.42420400 & -1.18300300 \\
\hline $\mathrm{C}$ & 3.36788400 & -4.78301800 & 1.09260000 \\
\hline $\mathrm{C}$ & 2.68402400 & -3.12271700 & -0.51991600 \\
\hline $\mathrm{C}$ & 2.60849600 & -4.10461300 & -1.50526700 \\
\hline $\mathrm{C}$ & 3.33391700 & -5.75550100 & 0.10349200 \\
\hline $\mathrm{C}$ & -1.05128600 & -3.20832200 & -2.35766300 \\
\hline $\mathrm{C}$ & -4.46665000 & 0.15607100 & -2.57584300 \\
\hline $\mathrm{C}$ & -2.38757400 & 2.58678200 & -2.13562600 \\
\hline $\mathrm{C}$ & 2.20781800 & 3.87467400 & -2.59214500 \\
\hline $\mathrm{C}$ & 3.29738300 & 0.85059400 & -2.31307700 \\
\hline $\mathrm{C}$ & 2.08700000 & -3.76352300 & -2.84386800 \\
\hline $\mathrm{N}$ & 2.11169600 & -2.57948000 & -3.28940000 \\
\hline $\mathrm{N}$ & -2.65652500 & 2.84279700 & -3.34562300 \\
\hline $\mathrm{N}$ & 3.58255900 & 0.98953500 & -3.53833000 \\
\hline $\mathrm{N}$ & 1.16946400 & 3.33320300 & -3.07141000 \\
\hline $\mathrm{N}$ & -3.48199500 & -0.44095200 & -3.10036000 \\
\hline $\mathrm{N}$ & -1.14903400 & -3.48677300 & -3.58847300 \\
\hline $\mathrm{C}$ & -3.01226900 & 0.05212100 & -4.39204300 \\
\hline $\mathrm{C}$ & -1.64058400 & 2.63370400 & -4.37740300 \\
\hline $\mathrm{C}$ & 1.28402800 & 2.72121200 & -4.39233400 \\
\hline $\mathrm{C}$ & 2.83204600 & 0.24534600 & -4.54980200 \\
\hline $\mathrm{C}$ & 1.44579400 & -2.33149000 & -4.56510200 \\
\hline $\mathrm{C}$ & -1.47600100 & -2.43380600 & -4.55010900 \\
\hline $\mathrm{C}$ & 0.64109300 & -1.04634700 & -4.46521600 \\
\hline $\mathrm{C}$ & -0.82976000 & 1.34116300 & -4.34236300 \\
\hline $\mathrm{C}$ & -0.76097600 & -1.09124400 & -4.42504900 \\
\hline $\mathrm{C}$ & 1.31203700 & 0.18608500 & -4.42509400 \\
\hline $\mathrm{C}$ & 0.57296500 & 1.37826400 & -4.38261200 \\
\hline $\mathrm{C}$ & -1.49360100 & 0.10543200 & -4.38229900 \\
\hline $\mathrm{H}$ & -0.65403500 & 3.24749300 & 4.34334200 \\
\hline $\mathrm{H}$ & 0.79394700 & 3.05139100 & 5.30422200 \\
\hline $\mathrm{H}$ & 2.68834900 & 2.11763900 & 4.67080600 \\
\hline $\mathrm{H}$ & 3.40599600 & 0.56579800 & 4.90800100 \\
\hline
\end{tabular}




\begin{tabular}{|c|c|c|c|}
\hline $\mathrm{H}$ & 3.39852900 & -1.18710300 & 4.10867200 \\
\hline $\mathrm{H}$ & 2.56415800 & -2.37400600 & 5.08504000 \\
\hline $\mathrm{H}$ & 0.77210200 & -3.53042100 & 4.52253900 \\
\hline $\mathrm{H}$ & -0.91329300 & -3.38584200 & 4.86574000 \\
\hline $\mathrm{H}$ & -2.47179200 & -2.48051300 & 4.18893800 \\
\hline $\mathrm{H}$ & -3.02258500 & -1.19736500 & 5.24166800 \\
\hline $\mathrm{H}$ & -3.16112300 & 0.94826700 & 4.75536200 \\
\hline $\mathrm{H}$ & -2.17486600 & 2.32645500 & 5.08359300 \\
\hline $\mathrm{H}$ & 2.33794800 & -3.73569900 & 3.21319200 \\
\hline $\mathrm{H}$ & 3.22029900 & 0.37609400 & 2.32485800 \\
\hline $\mathrm{H}$ & 2.08128900 & 3.66239800 & 3.46570200 \\
\hline $\mathrm{H}$ & -1.92571300 & 2.43694900 & 2.50224000 \\
\hline $\mathrm{H}$ & -4.19998500 & -0.26422100 & 3.46641100 \\
\hline $\mathrm{H}$ & -1.13949600 & -3.04799500 & 2.30162100 \\
\hline $\mathrm{H}$ & 5.95140100 & 3.62597400 & 1.42096300 \\
\hline $\mathrm{H}$ & 2.79080200 & 0.95028800 & 0.32034000 \\
\hline $\mathrm{H}$ & 6.77107300 & 3.61249300 & -0.93649300 \\
\hline $\mathrm{H}$ & 5.53421600 & 2.30445800 & -2.65896300 \\
\hline $\mathrm{H}$ & 2.56569400 & 5.53340100 & 2.47695800 \\
\hline $\mathrm{H}$ & 0.61300400 & 3.18459000 & -0.54248800 \\
\hline $\mathrm{H}$ & 4.07106900 & 6.47130200 & 0.77221700 \\
\hline $\mathrm{H}$ & 3.93978500 & 5.67633300 & -1.57306600 \\
\hline $\mathrm{H}$ & -6.10624600 & 3.23972100 & 1.66348200 \\
\hline $\mathrm{H}$ & -2.21203200 & 1.91929100 & 0.45736600 \\
\hline $\mathrm{H}$ & -6.51060800 & 4.11800900 & -0.63756000 \\
\hline $\mathrm{H}$ & -4.76502400 & 3.81934800 & -2.39001600 \\
\hline $\mathrm{H}$ & -6.06425800 & -0.71057300 & 2.45125500 \\
\hline $\mathrm{H}$ & -3.06456700 & -1.01714400 & -0.60733000 \\
\hline $\mathrm{H}$ & -7.63488400 & 0.24015300 & 0.81410000 \\
\hline $\mathrm{H}$ & -6.88972300 & 0.68441100 & -1.50892400 \\
\hline $\mathrm{H}$ & 0.23472700 & -7.00961800 & 1.19020200 \\
\hline $\mathrm{H}$ & -0.54805100 & -2.90054700 & 0.25986500 \\
\hline $\mathrm{H}$ & -0.33299600 & -7.63930300 & -1.15698000 \\
\hline $\mathrm{H}$ & -0.94367800 & -5.86096500 & -2.79208100 \\
\hline $\mathrm{H}$ & 3.64443500 & -5.05872700 & 2.10282000 \\
\hline $\mathrm{H}$ & 2.41839100 & -2.10000900 & -0.75895100 \\
\hline $\mathrm{H}$ & 3.59221500 & -6.77906200 & 0.34553100 \\
\hline $\mathrm{H}$ & 2.83095300 & -6.19550000 & -1.94135300 \\
\hline $\mathrm{H}$ & -1.14599400 & -2.18527200 & -1.97042200 \\
\hline $\mathrm{H}$ & -4.98232000 & 0.98554100 & -3.08019300 \\
\hline $\mathrm{H}$ & -1.42972400 & 2.15392100 & -1.81822500 \\
\hline $\mathrm{H}$ & 3.15150300 & 3.92566500 & -3.15363700 \\
\hline $\mathrm{H}$ & 2.46160000 & 0.22996200 & -1.96391600 \\
\hline $\mathrm{H}$ & 1.62383000 & -4.58817900 & -3.40397300 \\
\hline $\mathrm{H}$ & -3.34849200 & -0.63921200 & -5.16957600 \\
\hline $\mathrm{H}$ & -3.44407200 & 1.02801100 & -4.62777500 \\
\hline
\end{tabular}




$\begin{array}{lrrr}\mathrm{H} & -2.15836200 & 2.68753000 & -5.33990700 \\ \mathrm{H} & -0.98501400 & 3.50077900 & -4.32937600 \\ \mathrm{H} & 3.07947900 & 0.69616700 & -5.51570900 \\ \mathrm{H} & 3.25691000 & -0.75637800 & -4.55734400 \\ \mathrm{H} & 2.21027500 & -2.22443000 & -5.33951600 \\ \mathrm{H} & -1.26619100 & -2.84282800 & -5.54315500 \\ \mathrm{H} & 2.32896200 & 2.61703700 & -4.69492200 \\ \mathrm{H} & 0.81526500 & -3.17498800 & -4.85719400 \\ \mathrm{H} & -2.55452200 & -2.30236500 & -4.49119700 \\ \mathrm{H} & 0.80744100 & 3.38154100 & -5.12199200\end{array}$

\section{Carbonate inside of Molecule 1:}

\begin{tabular}{|c|c|c|c|}
\hline \multicolumn{4}{|c|}{$E(R M 062 X)=-4151.754593$} \\
\hline \multicolumn{4}{|c|}{ Cartesian Coordinates: } \\
\hline $\mathrm{C}$ & 0.10027500 & -0.45302700 & 4.43706900 \\
\hline $\mathrm{C}$ & 1.32450100 & -2.70087200 & 3.29078500 \\
\hline $\mathrm{C}$ & 1.48082100 & -0.44993900 & 4.18256100 \\
\hline $\mathrm{C}$ & -0.66448900 & -1.58127400 & 4.11403300 \\
\hline $\mathrm{C}$ & -0.05329500 & -2.70896600 & 3.54340300 \\
\hline $\mathrm{C}$ & 2.09499800 & -1.57259500 & 3.61290200 \\
\hline $\mathrm{C}$ & -0.59854200 & 0.80699100 & 4.92133300 \\
\hline $\mathrm{C}$ & 2.26015400 & 0.84078100 & 4.37020500 \\
\hline $\mathrm{C}$ & 3.56022400 & -1.49916800 & 3.21532900 \\
\hline $\mathrm{C}$ & 1.96991500 & -3.83424200 & 2.51139400 \\
\hline $\mathrm{C}$ & -0.89284300 & -3.88049800 & 3.06082800 \\
\hline $\mathrm{C}$ & -2.17997100 & -1.53664500 & 4.21284700 \\
\hline $\mathrm{N}$ & 3.70437600 & -0.64135700 & 2.04255300 \\
\hline $\mathrm{N}$ & 1.77832000 & 1.82851000 & 43100 \\
\hline $\mathrm{N}$ & -1.31384200 & 1.42561900 & 3.80873300 \\
\hline $\mathrm{N}$ & -2.74368000 & -1.53245800 & 2.86988100 \\
\hline $\mathrm{N}$ & -1.01051600 & -3.82978700 & 1.60626200 \\
\hline $\mathrm{N}$ & 2.34959400 & -3.34706900 & 1.19238400 \\
\hline $\mathrm{C}$ & -3.73922300 & -2.37798600 & 2.53965300 \\
\hline $\mathrm{C}$ & -2.13643000 & 2.46963400 & 4.03473100 \\
\hline $\mathrm{C}$ & 1.46101800 & 3.07520500 & 3.81440300 \\
\hline $\mathrm{C}$ & 4.93299400 & -0.30630400 & 1.60058200 \\
\hline $\mathrm{C}$ & 3.58304500 & -3.57879000 & 0.70251700 \\
\hline $\mathrm{C}$ & -1.58333800 & -4.85327100 & 0.94148400 \\
\hline $\mathrm{O}$ & -1.98730300 & -5.86588200 & 1.50222600 \\
\hline $\mathrm{O}$ & -4.32803100 & -3.07151900 & 3.36303200 \\
\hline $\mathrm{O}$ & -2.34918900 & 2.91593100 & 5.15663800 \\
\hline $\mathrm{O}$ & 1.70415600 & 3.49850300 & 4.94016200 \\
\hline $\mathrm{O}$ & 5.96156800 & -0.66120600 & 2.16558300 \\
\hline $\mathrm{O}$ & 4.38841600 & -4.32829900 & 1.24586600 \\
\hline $\mathrm{C}$ & 0.76197900 & 3.95254700 & 2.80656600 \\
\hline $\mathrm{C}$ & -0.55471500 & 5.70301500 & 1.07309900 \\
\hline
\end{tabular}




\begin{tabular}{|c|c|c|c|}
\hline $\mathrm{C}$ & 0.41039500 & 5.23310700 & 3.22772400 \\
\hline $\mathrm{C}$ & 0.43123600 & 3.53793600 & 1.51540000 \\
\hline $\mathrm{C}$ & -0.21096600 & 4.41863900 & 0.64527700 \\
\hline $\mathrm{C}$ & -0.24921100 & 6.10336400 & 2.36516300 \\
\hline $\mathrm{C}$ & -2.79272300 & 3.08879500 & 2.82208000 \\
\hline $\mathrm{C}$ & -3.96454200 & 4.38310000 & 0.63234300 \\
\hline $\mathrm{C}$ & -3.37666500 & 4.34240000 & 2.97384000 \\
\hline $\mathrm{C}$ & -2.81539000 & 2.47485100 & 1.56853200 \\
\hline $\mathrm{C}$ & -3.38965700 & 3.11880000 & 0.47463500 \\
\hline $\mathrm{C}$ & -3.96307500 & 4.98395600 & 1.88242000 \\
\hline $\mathrm{C}$ & -4.10630700 & -2.45549600 & 1.07903600 \\
\hline $\mathrm{C}$ & -4.90461000 & -2.73402100 & -1.58320600 \\
\hline $\mathrm{C}$ & -5.12862200 & -3.33767600 & 0.73621200 \\
\hline $\mathrm{C}$ & -3.46364900 & -1.72478900 & 0.07829500 \\
\hline $\mathrm{C}$ & -3.87438500 & -1.85227500 & -1.24848300 \\
\hline $\mathrm{C}$ & -5.52345300 & -3.47895400 & -0.59066000 \\
\hline $\mathrm{C}$ & -1.72190600 & -4.69325200 & -0.55490900 \\
\hline $\mathrm{C}$ & -2.14094900 & -4.43830100 & -3.31198500 \\
\hline $\mathrm{C}$ & -2.59520500 & -5.54988500 & -1.21744100 \\
\hline $\mathrm{C}$ & -1.04039300 & -3.71777700 & -1.28498400 \\
\hline $\mathrm{C}$ & -1.25294300 & -3.58145900 & -2.65505000 \\
\hline $\mathrm{C}$ & -2.79971500 & -5.42349900 & -2.59181200 \\
\hline $\mathrm{C}$ & 3.95588200 & -2.85286900 & -0.56569800 \\
\hline $\mathrm{C}$ & 4.81584100 & -1.57749900 & -2.89741000 \\
\hline $\mathrm{C}$ & 5.23712800 & -3.07926400 & -1.06386700 \\
\hline $\mathrm{C}$ & 3.10741400 & -1.96404200 & -1.22794400 \\
\hline $\mathrm{C}$ & 3.53194400 & -1.34033000 & -2.40093400 \\
\hline $\mathrm{C}$ & 5.66641100 & -2.44075000 & -2.22337800 \\
\hline $\mathrm{C}$ & 4.99352200 & 0.53381800 & 0.34559700 \\
\hline $\mathrm{C}$ & 5.21788400 & 1.98090900 & -2.04155900 \\
\hline $\mathrm{C}$ & 6.21425100 & 0.61678800 & -0.31653100 \\
\hline $\mathrm{C}$ & 3.88557500 & 1.19781900 & -0.18388400 \\
\hline $\mathrm{C}$ & 3.99060500 & 1.91143500 & -1.37584700 \\
\hline $\mathrm{C}$ & 6.32471400 & 1.34127500 & -1.50384000 \\
\hline $\mathrm{C}$ & 2.61380900 & -0.41238800 & -3.09010200 \\
\hline $\mathrm{C}$ & -0.60307200 & -2.45147600 & -3.34808100 \\
\hline $\mathrm{C}$ & -3.18842400 & -1.06048700 & -2.28851600 \\
\hline $\mathrm{C}$ & -3.27302900 & 2.47396000 & -0.84839800 \\
\hline $\mathrm{C}$ & -0.54267500 & 3.96219900 & -0.71874700 \\
\hline $\mathrm{C}$ & 2.75773400 & 2.48556200 & -1.95030100 \\
\hline $\mathrm{N}$ & 2.73872600 & 3.07258700 & -3.07426400 \\
\hline $\mathrm{N}$ & -3.64921300 & -0.96995900 & -3.4649870 \\
\hline $\mathrm{N}$ & -0.92188400 & 4.77293800 & -1.61511400 \\
\hline $\mathrm{N}$ & -3.68505100 & 3.02498500 & -1.91371300 \\
\hline $\mathrm{N}$ & -0.81252000 & -2.19173800 & -4.57161100 \\
\hline $\mathrm{N}$ & 2.85546000 & 0.01493600 & -4.25780300 \\
\hline
\end{tabular}




\begin{tabular}{|c|c|c|c|}
\hline $\mathrm{C}$ & -0.15684000 & -1.00780100 & -5.13487100 \\
\hline $\mathrm{C}$ & -2.92855000 & -0.22060800 & -4.48319100 \\
\hline $\mathrm{C}$ & -3.46608500 & 2.31184900 & -3.17557400 \\
\hline $\mathrm{C}$ & -1.28883800 & 4.29117500 & -2.93831500 \\
\hline $\mathrm{C}$ & 1.44385600 & 3.55127800 & -3.56727100 \\
\hline $\mathrm{C}$ & 1.95611300 & 0.96408400 & -4.89653400 \\
\hline $\mathrm{C}$ & 0.33139400 & 2.50728300 & -3.69604300 \\
\hline $\mathrm{C}$ & -1.75872800 & 0.67117900 & -4.08617800 \\
\hline $\mathrm{C}$ & 0.59487300 & 1.25827400 & -4.27841500 \\
\hline $\mathrm{C}$ & -0.98371600 & 2.85257600 & -3.33658900 \\
\hline $\mathrm{C}$ & -2.02191100 & 1.92355200 & -3.50301400 \\
\hline $\mathrm{C}$ & -0.44629000 & 0.32739500 & -4.44381100 \\
\hline $\mathrm{H}$ & -1.31352900 & 0.58239400 & 5.71625100 \\
\hline $\mathrm{H}$ & 0.09952100 & 1.52621400 & 5.35232700 \\
\hline $\mathrm{H}$ & 2.12215400 & 1.25470300 & 5.36949400 \\
\hline $\mathrm{H}$ & 3.32880200 & 0.68696300 & 4.23234700 \\
\hline $\mathrm{H}$ & 4.17009200 & -1.09197200 & 4.02519100 \\
\hline $\mathrm{H}$ & 3.97947300 & -2.48347700 & 3.00170400 \\
\hline $\mathrm{H}$ & 2.87388000 & -4.19799300 & 3.00073200 \\
\hline $\mathrm{H}$ & 1.29712000 & -4.68375000 & 2.40961200 \\
\hline $\mathrm{H}$ & -0.44078400 & -4.83422600 & 3.34300400 \\
\hline $\mathrm{H}$ & -1.88814200 & -3.88649000 & 3.50767100 \\
\hline $\mathrm{H}$ & -2.57702300 & -2.40842300 & 4.73358400 \\
\hline $\mathrm{H}$ & -2.51979600 & -0.65702100 & 4.75641600 \\
\hline $\mathrm{H}$ & 2.84580300 & -0.37652600 & 1.54048900 \\
\hline $\mathrm{H}$ & 1.48592000 & 1.45106000 & 2.50455000 \\
\hline $\mathrm{H}$ & -1.10667700 & 1.08100000 & 2.86156900 \\
\hline $\mathrm{H}$ & -2.19412500 & -1.02650300 & 2.16424700 \\
\hline $\mathrm{H}$ & -0.71371800 & -2.96398400 & 1.13588300 \\
\hline $\mathrm{H}$ & 1.71768400 & -2.64671300 & 0.78478900 \\
\hline $\mathrm{H}$ & 0.65446800 & 5.51600700 & 4.24439600 \\
\hline $\mathrm{H}$ & 0.64208600 & 2.52563200 & 1.17138700 \\
\hline $\mathrm{H}$ & -0.53549500 & 7.09111800 & 2.70928600 \\
\hline $\mathrm{H}$ & -1.07540400 & 6.35657500 & 0.38331900 \\
\hline $\mathrm{H}$ & -3.34711600 & 4.80413600 & 3.95385900 \\
\hline $\mathrm{H}$ & -2.34618300 & 1.50938300 & 1.40920200 \\
\hline $\mathrm{H}$ & -4.40028500 & 5.96834800 & 2.00971900 \\
\hline $\mathrm{H}$ & -4.38327000 & 4.87887900 & -0.23577600 \\
\hline $\mathrm{H}$ & -5.58869200 & -3.91218400 & 1.53088000 \\
\hline $\mathrm{H}$ & -2.62484300 & -1.06660500 & 0.30391300 \\
\hline $\mathrm{H}$ & -6.30783800 & -4.18188900 & -0.84889200 \\
\hline $\mathrm{H}$ & -5.18566100 & -2.82994900 & -2.6252790 \\
\hline $\mathrm{H}$ & -3.11691800 & -6.29922000 & -0.6336150 \\
\hline $\mathrm{H}$ & -0.37213500 & -3.01716500 & -0.7950820 \\
\hline $\mathrm{H}$ & -3.49649100 & -6.08585800 & -3.0939850 \\
\hline $\mathrm{H}$ & -2.31319700 & -4.29887000 & -4.3729350 \\
\hline
\end{tabular}




$\begin{array}{lrrr}\mathrm{H} & 5.88264600 & -3.75210500 & -0.51266900 \\ \mathrm{H} & 2.11912200 & -1.72305400 & -0.83702400 \\ \mathrm{H} & 6.67203100 & -2.60985700 & -2.59240100 \\ \mathrm{H} & 5.12672200 & -1.06031900 & -3.79739300 \\ \mathrm{H} & 7.06215500 & 0.09242400 & 0.10843600 \\ \mathrm{H} & 2.91298800 & 1.13179900 & 0.29290000 \\ \mathrm{H} & 7.27769100 & 1.38429200 & -2.01995500 \\ \mathrm{H} & 5.27321400 & 2.51848500 & -2.98107100 \\ \mathrm{H} & 1.71787300 & -0.12184900 & -2.52192500 \\ \mathrm{H} & 0.03355500 & -1.82187800 & -2.70879800 \\ \mathrm{H} & -2.25956700 & -0.56380400 & -1.97152800 \\ \mathrm{H} & -2.75503600 & 1.50342900 & -0.84493400 \\ \mathrm{H} & -0.44092300 & 2.88128700 & -0.89564400 \\ \mathrm{H} & 1.84888700 & 2.31867200 & -1.35324700 \\ \mathrm{H} & 0.91750200 & -1.19275400 & -5.15212000 \\ \mathrm{H} & -0.47905400 & -0.93072200 & -6.17974400 \\ \mathrm{H} & -2.60316100 & -0.95916400 & -5.21896700 \\ \mathrm{H} & -3.67401700 & 0.39659900 & -4.99663000 \\ \mathrm{H} & -2.35842200 & 4.48818200 & -3.03821500 \\ \mathrm{H} & -0.79947500 & 4.95926000 & -3.65561700 \\ \mathrm{H} & 1.11717000 & 4.36576700 & -2.92018700 \\ \mathrm{H} & 2.52742300 & 1.88918600 & -5.00004000 \\ \mathrm{H} & -3.83697000 & 2.96082100 & -3.97730800 \\ \mathrm{H} & 1.62066200 & 3.98830000 & -4.55685800 \\ \mathrm{H} & 1.79963500 & 0.59990900 & -5.91795300 \\ \mathrm{H} & -4.09992700 & 1.42473200 & -3.17422100 \\ \mathrm{C} & 0.17649900 & -0.38413100 & 0.93848300 \\ \mathrm{O} & -0.96433300 & 0.06471900 & 1.32792200 \\ \mathrm{O} & 1.22807800 & 0.34842300 & 1.05091600 \\ \mathrm{O} & 0.26583200 & -1.56503600 & 0.43637300\end{array}$




\section{X-Ray Diffraction Data}

The single crystal X-ray diffraction studies were carried out on a Bruker Kappa Photon II CPAD diffractometer equipped with Mo K $_{\alpha}$ radiation $(\lambda=0.71073 \AA$ ). A $0.468 \times 0.214 \times 0.173 \mathrm{~mm}$ piece of a colorless plate was mounted on a MiTeGen Micromount with CHRISTO-LUBE MCG 1024 oil. Data were collected in a nitrogen gas stream at $100(2) \mathrm{K}$ using $\phi$ and $\varpi$ scans. Crystal-to-detector distance was 60 $\mathrm{mm}$ using variable exposure time (10s-30s) depending on $\theta$ with a scan width of $1.0^{\circ}$. Data collection was $99.9 \%$ complete to $25.00^{\circ}$ in $\theta$. A total of 166835 reflections were collected covering the indices, $-17<=\mathrm{h}<=17,-26<=\mathrm{k}<=26,-24<=\mid<=24.11367$ reflections were found to be symmetry independent, with a $R_{\text {int }}$ of 0.0518 . Indexing and unit cell refinement indicated a primitive, monoclinic lattice. The space group was found to be $P 2_{1} / \mathrm{n}$. The data were integrated using the Bruker SAINT software program and scaled using the SADABS software program. Solution by direct methods (SHELXT) produced a complete phasing model for refinement.

All nonhydrogen atoms were refined anisotropically by full-matrix least-squares (SHELXL-2014). All carbon bonded hydrogen atoms were placed using a riding model. Their positions were constrained relative to their parent atom using the appropriate HFIX command in SHELXL-2014. All other hydrogen atoms (H-bonding) were located in the difference map. Their relative positions were restrained using DFIX commands and their thermals freely refined. Crystallographic data are summarized in Table S1. 


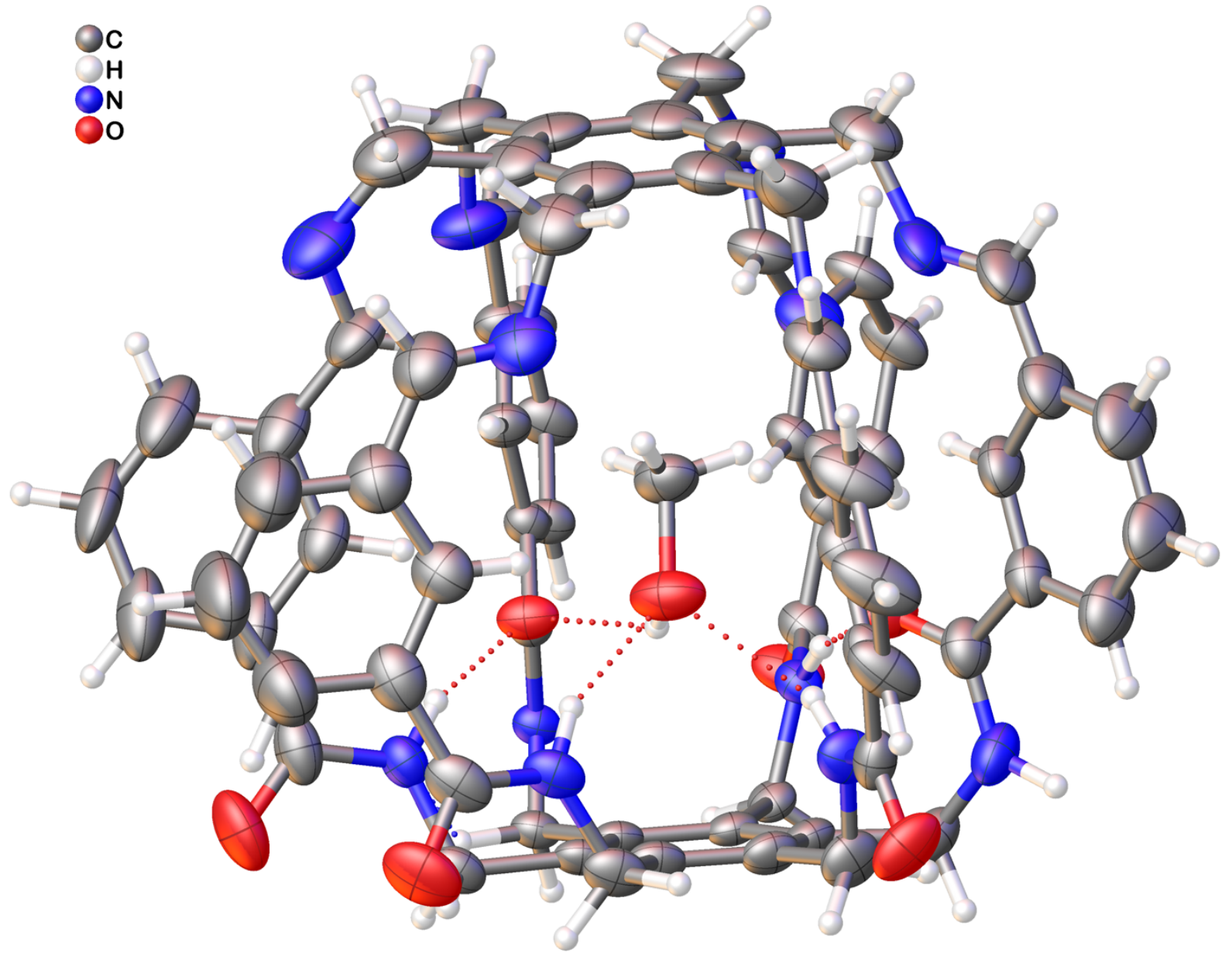


Table S1. Crystal data and structure refinement for $\left[\mathrm{CH}_{3} \mathrm{OH} \subset \mathbf{1}\right]$.

\begin{tabular}{|c|c|c|}
\hline Report date & \multicolumn{2}{|l|}{ 2020-09-04 } \\
\hline Identification code & \multicolumn{2}{|l|}{ HXieCageMeOH } \\
\hline Empirical formula & \multicolumn{2}{|c|}{ C74.58 H69.45 N12 O8.15 } \\
\hline Molecular formula & \multicolumn{2}{|c|}{ C72 H60 N12 O6, 2(C H4 O), 0.1453(C4 H10 O) } \\
\hline Formula weight & \multicolumn{2}{|l|}{1264.18} \\
\hline Temperature & \multicolumn{2}{|l|}{$100.0 \mathrm{~K}$} \\
\hline Wavelength & \multicolumn{2}{|l|}{$0.71073 \AA$} \\
\hline Crystal system & \multicolumn{2}{|l|}{ Monoclinic } \\
\hline Space group & \multicolumn{2}{|l|}{ P $121 / n 1$} \\
\hline \multirow[t]{3}{*}{ Unit cell dimensions } & $a=14.2015(9) \AA$ & $\alpha=90^{\circ}$. \\
\hline & $\mathrm{b}=21.7587(16) \AA$ & $\beta=100.151(2)^{\circ}$ \\
\hline & $c=20.3574(15) \AA$ & $\gamma=90^{\circ}$ \\
\hline Volume & \multicolumn{2}{|l|}{$6192.1(8) \AA^{3}$} \\
\hline $\mathrm{Z}$ & \multicolumn{2}{|l|}{4} \\
\hline Density (calculated) & \multicolumn{2}{|l|}{$1.356 \mathrm{Mg} / \mathrm{m}^{3}$} \\
\hline Absorption coefficient & \multicolumn{2}{|l|}{$0.090 \mathrm{~mm}^{-1}$} \\
\hline $\mathrm{F}(000)$ & \multicolumn{2}{|l|}{2664} \\
\hline Crystal size & \multicolumn{2}{|c|}{$0.468 \times 0.214 \times 0.173 \mathrm{~mm}^{3}$} \\
\hline Crystal color, habit & \multicolumn{2}{|l|}{ Colorless Block } \\
\hline Theta range for data collection & \multicolumn{2}{|l|}{2.860 to $25.387^{\circ}$. } \\
\hline Index ranges & \multicolumn{2}{|c|}{$-17<=\mathrm{h}<=17,-26<=\mathrm{k}<=26,-24<=\mathrm{l}<=24$} \\
\hline Reflections collected & \multicolumn{2}{|l|}{166835} \\
\hline Independent reflections & \multicolumn{2}{|c|}{$11367[\mathrm{R}(\mathrm{int})=0.0518, \mathrm{R}($ sigma $)=0.0227]$} \\
\hline Completeness to theta $=25.000^{\circ}$ & \multicolumn{2}{|l|}{$99.9 \%$} \\
\hline Absorption correction & \multicolumn{2}{|c|}{ Semi-empirical from equivalents } \\
\hline Max. and min. transmission & \multicolumn{2}{|l|}{0.2590 and 0.2329} \\
\hline Refinement method & \multicolumn{2}{|c|}{ Full-matrix least-squares on $\mathrm{F}^{2}$} \\
\hline Data / restraints / parameters & \multicolumn{2}{|l|}{11367 / 285 / 928} \\
\hline Goodness-of-fit on $\mathrm{F}^{2}$ & \multicolumn{2}{|l|}{1.035} \\
\hline Final $\mathrm{R}$ indices $[\mathrm{I}>2 \operatorname{sigma}(\mathrm{I})]$ & \multicolumn{2}{|c|}{$\mathrm{R} 1=0.0690, w \mathrm{R} 2=0.1783$} \\
\hline $\mathrm{R}$ indices (all data) & \multicolumn{2}{|c|}{$\mathrm{R} 1=0.0937, \mathrm{wR} 2=0.2030$} \\
\hline Extinction coefficient & \multicolumn{2}{|l|}{$\mathrm{n} / \mathrm{a}$} \\
\hline Largest diff. peak and hole & \multicolumn{2}{|c|}{0.570 and -0.373 e. $\AA^{-3}$} \\
\hline
\end{tabular}


The single crystal X-ray diffraction studies were carried out on a Bruker Kappa Photon II CPAD diffractometer equipped with Mo K $_{\alpha}$ radiation $(\lambda=0.71073 \AA$ ). A $0.237 \times 0.187 \times 0.171 \mathrm{~mm}$ piece of a colorless block was mounted on a MiTeGen Micromount with Paratone 24EX oil. Data were collected in a nitrogen gas stream at $100(2) \mathrm{K}$ using $\phi$ and $\varpi$ scans. Crystal-to-detector distance was $80 \mathrm{~mm}$ and exposure time was 120 seconds per frame using a scan width of $1.0^{\circ}$. Data collection was $99.6 \%$ complete to $21.994^{\circ}$ in $\theta(0.95 \AA)$. A total of 215051 reflections were collected covering the indices, $-24<=\mathrm{h}<=24$, $43<=k<=43,-18<=\mid<=18.21034$ reflections were found to be symmetry independent, with a $R_{\text {int }}$ of 0.0841 . Indexing and unit cell refinement indicated a primitive, monoclinic lattice. The space group was found to be $P 2_{1} / c$. The data were integrated using the Bruker SAINT software program and scaled using the SADABS software program. Solution by direct methods (SHELXT) produced a complete phasing model for refinement.

All nonhydrogen atoms were refined anisotropically by full-matrix least-squares (SHELXL-2014). All hydrogen atoms were placed using a riding model. Their positions were constrained relative to their parent atom using the appropriate HFIX command in SHELXL-2014. Crystallographic data are summarized in Table S2. 


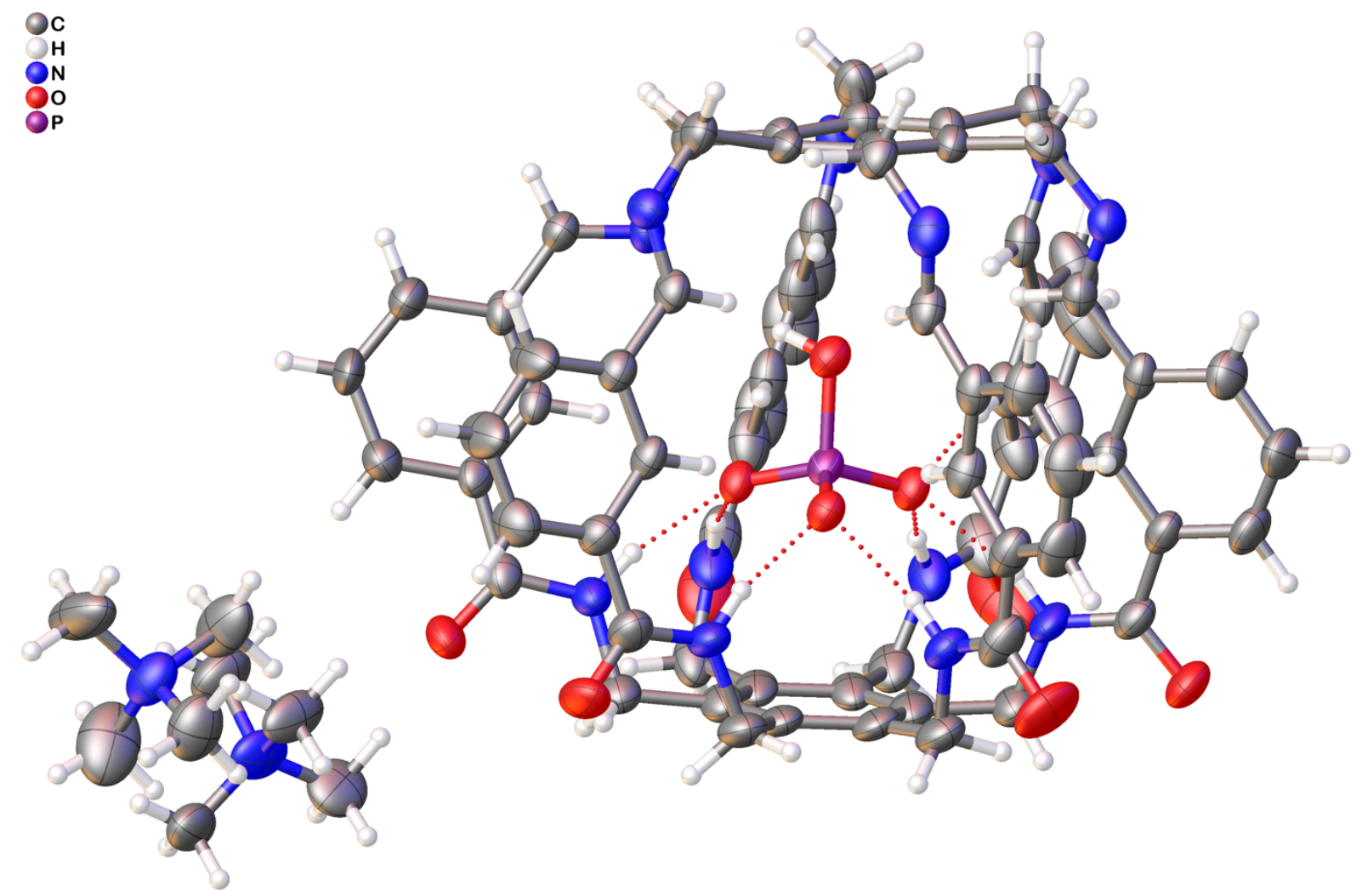


Table S2. Crystal data and structure refinement for $\left[\mathrm{HPO}_{4} \subset \mathbf{1}\right] \mathrm{TMA}_{2}$.

Report date

Identification code

Empirical formula

Molecular formula

Formula weight

Temperature

Wavelength

Crystal system

Space group

Unit cell dimensions

Volume

Z

Density (calculated)

Absorption coefficient

$\mathrm{F}(000)$

Crystal size

Crystal color, habit

Theta range for data collection

Index ranges

Reflections collected

Independent reflections

Completeness to theta $=21.994^{\circ}$

Absorption correction

Max. and min. transmission

Refinement method

Data / restraints / parameters

Goodness-of-fit on $\mathrm{F}^{2}$

Final R indices [I $>2 \operatorname{sigma}(\mathrm{I})]$

$\mathrm{R}$ indices (all data)

Extinction coefficient

Largest diff. peak and hole
2020-10-27

HXieHPO4

C91.50 H115.67 N14 O16.71 P

H O4 P, C72 H60 N12 O6, 2(C4 H12 N), 2.875(C4 H8 O), $3.833(\mathrm{H} 2 \mathrm{O})$

1709.95

$100.0 \mathrm{~K}$

$0.71073 \AA$

Monoclinic

P 1 21/c 1

$a=23.5726(19) \AA \quad \alpha=90^{\circ}$.

$\mathrm{b}=41.724(3) \AA \quad \beta=92.990(2)^{\circ}$.

$\mathrm{c}=17.5242(14) \AA \quad \gamma=90^{\circ}$.

17212(2) $\AA^{3}$

8

$1.320 \mathrm{Mg} / \mathrm{m}^{3}$

$0.109 \mathrm{~mm}^{-1}$

7291

$0.237 \times 0.187 \times 0.171 \mathrm{~mm}^{3}$

Colorless Block

2.820 to $21.994^{\circ}$.

$-24<=\mathrm{h}<=24,-43<=\mathrm{k}<=43,-18<=\mathrm{l}<=18$

215051

$21034[\mathrm{R}($ int $)=0.0841, \mathrm{R}($ sigma $)=0.0477]$

$99.6 \%$

Semi-empirical from equivalents

0.0869 and 0.0634

Full-matrix least-squares on $\mathrm{F}^{2}$

21034 / 557 / 2410

1.068

$\mathrm{R} 1=0.0975, \mathrm{wR} 2=0.2266$

$\mathrm{R} 1=0.1431, \mathrm{wR} 2=0.2569$

$\mathrm{n} / \mathrm{a}$

0.788 and -0.541 e. $\AA^{-3}$ 
The single crystal X-ray diffraction studies were carried out on a Bruker Kappa Photon II CPAD diffractometer equipped with Mo K $_{\alpha}$ radiation $(\lambda=0.71073 \AA$ A $) . \quad$ A $0.153 \times 0.076 \times 0.048 \mathrm{~mm}$ piece of a colorless plate was mounted on a MiTeGen Micromount with CHRISTO-LUBE MCG 1024 oil. Data were collected in a nitrogen gas stream at $100(2) \mathrm{K}$ using $\phi$ and $\varpi$ scans. Crystal-to-detector distance was 100 $\mathrm{mm}$ using variable exposure time (30s-120s) depending on $\theta$ with a scan width of $1.0^{\circ}$. Data collection was $98.2 \%$ complete to $22.143^{\circ}$ in $\theta, 0.94 \AA$. A total of 257043 reflections were collected covering the indices, $-51<=\mathrm{h}<=51,-16<=\mathrm{k}<=16,-25<=\mid<=25.23553$ reflections were found to be symmetry independent, with a $\mathrm{R}_{\text {int }}$ of 0.1480 . Indexing and unit cell refinement indicated a primitive, orthorhombic lattice. The space group was found to be $P$ na2 ${ }_{1}$. The data were integrated using the Bruker SAINT software program and scaled using the SADABS software program. Solution by direct methods (SHELXT) produced a complete phasing model for refinement.

All nonhydrogen atoms were refined anisotropically by full-matrix least-squares (SHELXL-2014). All hydrogen atoms were placed using a riding model. Their positions were constrained relative to their parent atom using the appropriate HFIX command in SHELXL-2014. Crystallographic data are summarized in Table S3. 


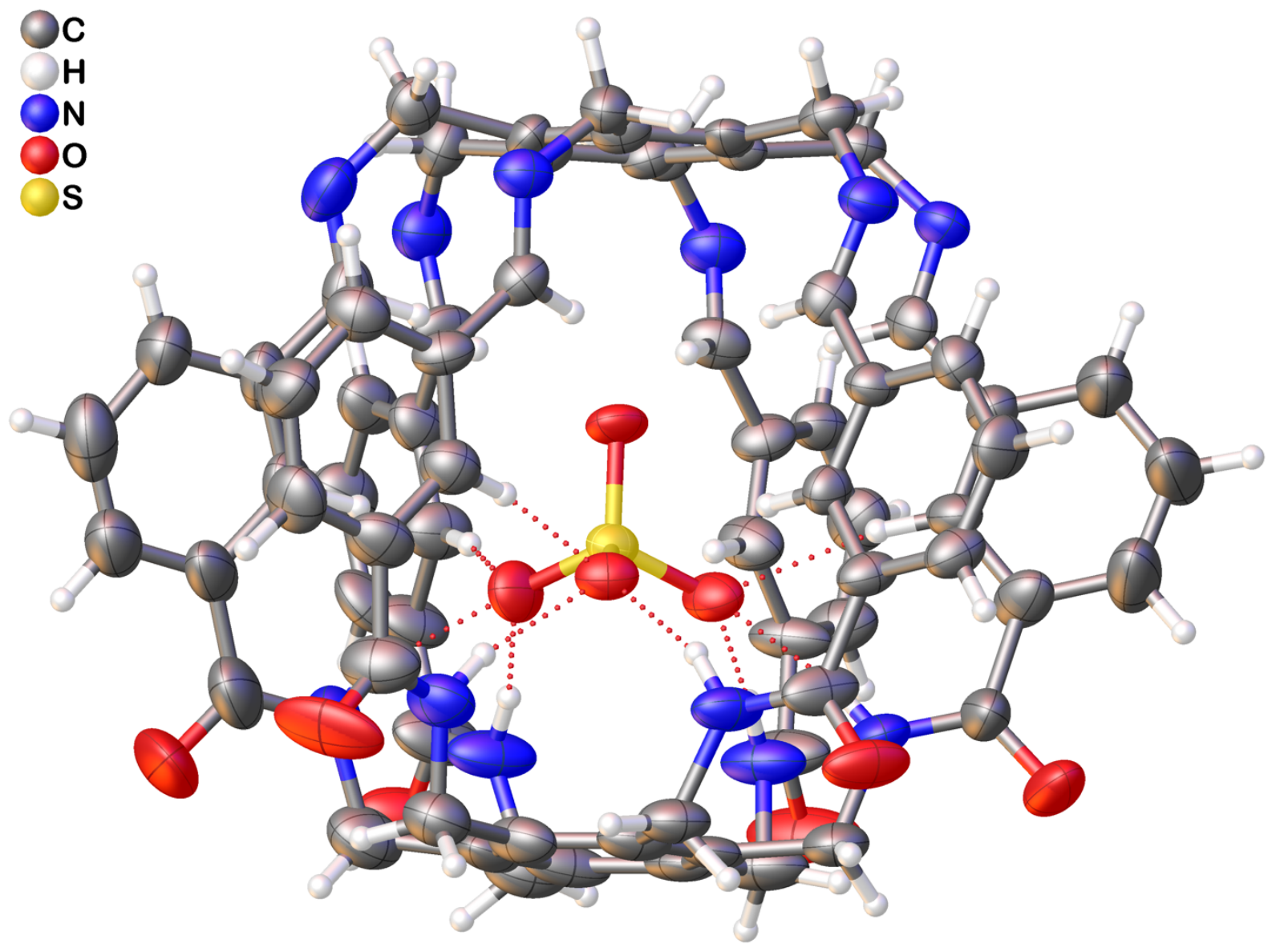


Table S3. Crystal data and structure refinement for $\left[\mathrm{SO}_{4} \subset \mathbf{1}\right] \mathrm{TBA}_{2}$.

Report date

Identification code

Empirical formula

Molecular formula

Formula weight

Temperature

Wavelength

Crystal system

Space group

Unit cell dimensions

Volume

Z

Density (calculated)

Absorption coefficient

$\mathrm{F}(000)$

Crystal size

Crystal color, habit

Theta range for data collection

Index ranges

Reflections collected

Independent reflections

Completeness to theta $=22.143^{\circ}$

Absorption correction

Max. and min. transmission

Refinement method

Data / restraints / parameters

Goodness-of-fit on $\mathrm{F}^{2}$

Final $\mathrm{R}$ indices [I $>2 \operatorname{sigma}(\mathrm{I})]$

$\mathrm{R}$ indices (all data)

Absolute structure parameter

Extinction coefficient

Largest diff. peak and hole
2020-11-06

HXieSO4

C104 H135.75 N14 O11.88 S

O4 S, C72 H60 N12 O6, 2(C16 H36 N), 1.875(H2 O)

1804.07

$100.0 \mathrm{~K}$

$0.71073 \AA$

Orthorhombic

Pna21

$\mathrm{a}=49.135(11) \AA \quad \alpha=90^{\circ}$.

$\mathrm{b}=16.083(4) \AA \quad \beta=90^{\circ}$.

$\mathrm{c}=24.301(6) \AA \quad \gamma=90^{\circ}$.

19204(8) $\AA^{3}$

8

$1.248 \mathrm{Mg} / \mathrm{m}^{3}$

$0.103 \mathrm{~mm}^{-1}$

7750

$0.153 \times 0.076 \times 0.048 \mathrm{~mm}^{3}$

Colorless Block

2.822 to $22.143^{\circ}$.

$-51<=\mathrm{h}<=51,-16<=\mathrm{k}<=16,-25<=1<=25$

257043

$23553[\mathrm{R}($ int $)=0.1480, \mathrm{R}($ sigma $)=0.0771]$

$98.2 \%$

Semi-empirical from equivalents

0.0815 and 0.0592

Full-matrix least-squares on $\mathrm{F}^{2}$

23553 / 2247 / 2943

1.067

$\mathrm{R} 1=0.0864, \mathrm{wR} 2=0.2116$

$\mathrm{R} 1=0.1290, \mathrm{wR} 2=0.2430$

$0.55(19)$

$\mathrm{n} / \mathrm{a}$

0.530 and -0.386 e. $\AA^{-3}$ 